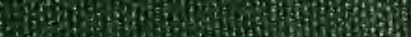

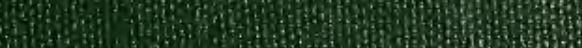

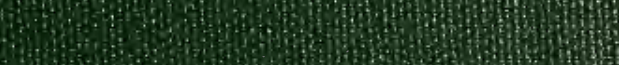
19.4. Q6)

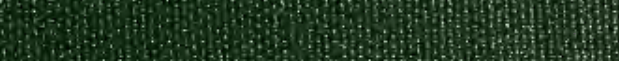

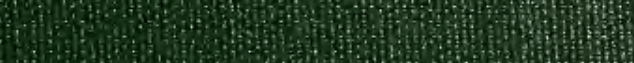

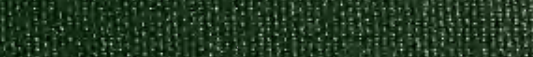
(2)

4.9.

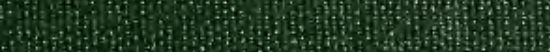
2. 1.

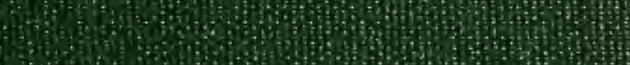
Hom 16.20 19 (2)

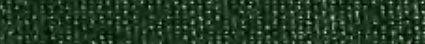

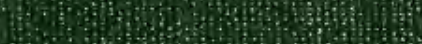

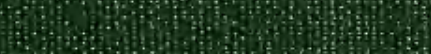
(4) (1)

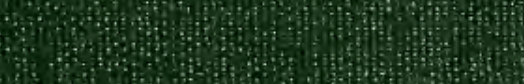
(19) Hats a. H.

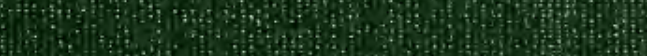

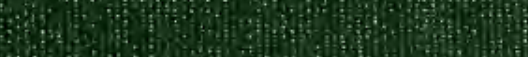
istis:

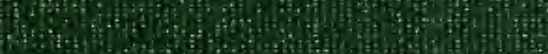

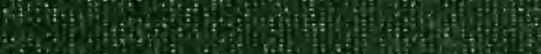
(6) (5) (6) 6. W Hat (4) 4 (1)

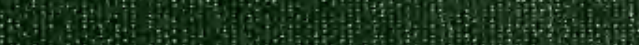
H.

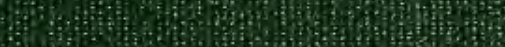
6.

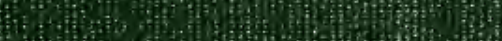
1. 2. 9

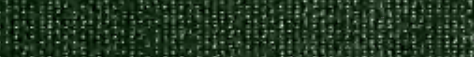

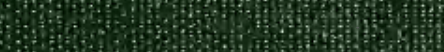

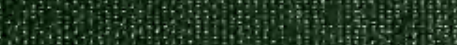
(4)

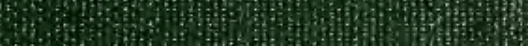
D. 13: (15)

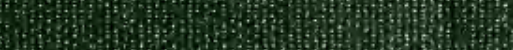



Digitized by the Internet Archive in 2011 with funding from

LYRASIS members and Sloan Foundation

http://www.archive.org/details/plantpesthandboo344brit 



\section{PLANT PEST HANDBOOK FOR CONNECTICUT}

\section{INSECTS}

W. E. BRITTON

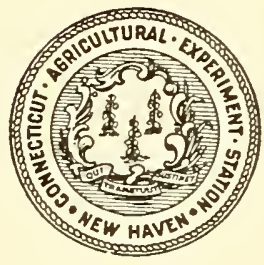

(Timentirat 


\section{CONNECTICUT AGRICULTURAL EXPERIMENT STATION}

\section{BOARD OF CONTROL}

His Excellency, Governor Wilbur L. Cross, ex-officio, President

Elijah Rogers, Vice-President.................. Southington George A. Hopson, Secretary. . . . . . . . . . . . . . . . . . . . Mount Carmel William L. Slate, Director and Treasurer. .............. New Haven

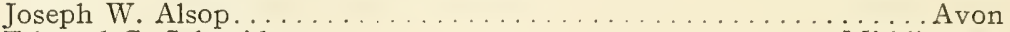
Edward C. Schneider....... . . . . . . . . . . . . . Middletown S. McLean Buckingham.... . ...............Watertown Charles G. Morris............................. Newtown

\section{STAFF}

Administration.

Analytical Chemistry.

Biochemistry.

Botany.

Entomology.

Forestry.

Plant Brceding.

Soils.

Tobacco Substation at Windsor.
William L. Slate, B.Sc., Director and Treasurer.

Miss L. M. BRAUTLECHT, Bookkeeper and Librarian.

Miss Dorothy AMrine, B. LitT, Editor.

G. E. Graham, In Charge of Buildings and Grounds.

E. M. Bailey, Ph.D., Chemist in Charge.

C. E. SHEPARD

OWEN L. NOLAN

HARRY J. Fisher, Ph.D. Assistant Chemists.

W. T. MATHIS

DAVID C. WALDEN, B.S.

FRANK C. SHELDON, Laboratory Assistant.

V. L. Churchill, Sampling Agent.

Mrs. A. B. Vosburgh, Secretary.

H. B. VICKery, PH.D., Biochemist in Charge.

Lafayetie B. Mendel, Ph.D., Research Associale (Yale University). George W. Pucher, PH.D., Assistant Biochemist.

G. P. Clinton, Sc.D., Botanist in Charge.

E. M. STODDARD, B.S., Pomologist.

Miss Florence A. MCCORMick, PH.D., Pathologist.

A. A. Dunlap, Ph.D., Assistant Mycologist.

A. D. McDonNell, General A ssistant.

Mrs. W. W. Kelsey, Secretary.

W. E. Britton, PH.D., D.Sc., Entomologist in Charge, State Entomologist.

B. H. WALDEN, B.AGR

M. P. ZAPPE, B.S.

Philip Garman, Ph.D.

ROGER B. FRIEND, PH.D.

NEELY TURNER, M.A.

JoHN T. Ashworth, Deputy in Charge of Gipsy Moth Control.

R. C. BOTSFORD, Depuly in Charge of Mosquito Elimination.

J. P. Johnson, B.S., Deputy in Charge of Asiatic and Japanese Beetle Quarantines.

Mrs. GlaDYS BroOKe, B.A., Secretary.

Walter O. Filley, Forester in Charge.

H. W. Hicock, M.F., A ssistant Forester.

J. E. Riley, JR., M.F., In Charge of Blister Rust Control.

Miss Pauline A. Merchant, Secretary.

Donald F. Jones, Sc.D., Geneticist in Charge.

W. Ralph Singleton, Sc.D., A ssistant Geneticist.

LAWRENCE C. CURTIS, B.S., Assistant.

M. F. Morgan, M.S., A gronomist in Charge.

H. G. M. JA COBSON, M.S., A ssistant A gronomist.

HER BERT A. Lunt, PH.D., A ssistant in Forest Soils.

Dwight B. Downs, General Assistant.

Paul J. Anderson, Ph.D., Pathologist in Charge.

T. R. SWanBack, M.S., Agronomist.

O. E. Street, M.S., Plant Physiologist.

Miss Dorothy Lenard, Secretary. 


\section{FOREWORD}

In 1903, the Station issued its first Spray Calendar, one of the earliest publications of its type. It was a card giving formulas and schedules with an attached pad giving simple descriptions of the pests under each host. This type of publication has been widely adopted and serves a very useful purpose.

Several revisions were issued and in 1915 there were added text illustrations of a large number of insects and diseases. This proved a most useful and popular bulletin. The last revision, Bulletin 271, 1926, has been out of print for some time and since the demand continues, and new pests are constantly appearing, it seemed wise to make a thorough revision before printing.

The bulletin has long since outgrown the scope of a "Spray Calendar." A more suitable title is the one chosen, A Plant Pest Handbook. The size and scope make it necessary to issue two parts, this being Part I, which deals with Insects. Part II will cover Diseases and similar troubles. The arrangement is as before, in which both hosts and pests are listed alphabetically by their common names.

There has been no attempt to list all of the insects that occur on all of the cultivated plants, but the more important insect pests of the common economic and ornamental plants are given, and certain new and conspicuous forms are included. 


\section{CONTENTS}

Page

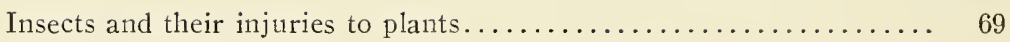

Principal insect pests of cultivated plants................. 70

(Hosts and insects arranged alphabetically by common names)

Formulas for insecticides........................... 178

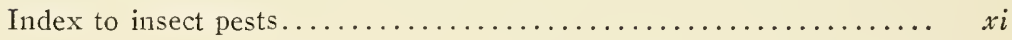




\title{
PLANT PEST HANDBOOK FOR CONNECTICUT
}

\section{INSECTS}

\author{
W. E. Britton
}

\section{INSECTS AND THEIR INJURIES TO PLANTS}

Insects are small animals belonging to the class Hexapoda (six-legged) and most of them have six legs in some stage of their existence. Spiders, mites, sow bugs, centipedes and millipedes are animals, but not insects, and all but certain mites have more than six legs. Insects may be divided roughly into two groups: (1) chewing or biting insects, and (2) sucking insects. The chewing insects (except termites or white ants, and grasshoppers and crickets) have four distinct stages in their life cycles, as follows: (1) Egg, (2) caterpillar, grub or larva, (3) pupa, (4) adult insect. Such insects are said to have complete transformations. The exceptions noted above and the sucking insects do not pass through these four wellmarked stages. There are usually, though not always, an egg stage, and an adult stage, but there is no pupa (except in case of the males in certain species of scale insects and white flies). The larvae are called nymphs after hatching from the eggs, and undergo a gradual development, molting several times with only slight changes until the adult stage is reached.

Certain insects like the butterflies and moths have sucking mouth parts in the adult stage and chewing mouth parts in the larval stage.

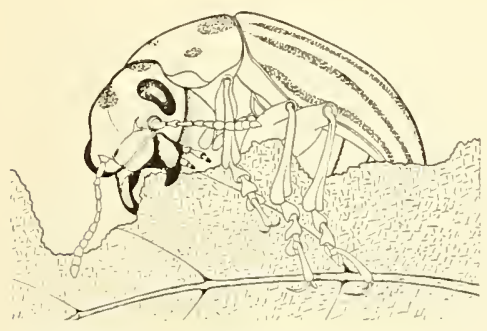

Figure 1. Motth parts of a chewing insect.

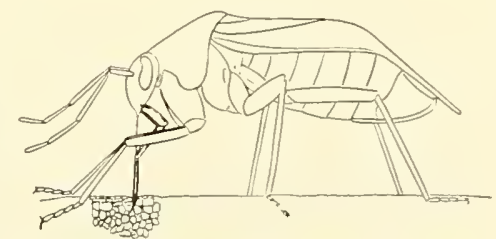

Figure 2. Mouth parts of a sucking illsect.

Chewing or biting insects have strong jaws or mandibles with which they bite or tear off bits of food, like the higher animals. Such insects swallow their food and here is where an arsenical poison can be employed with success. This class includes all caterpillars, beetles, sawflies, grasshoppers, and crickets.

Sucking insects puncture the tissues with their beaks or probosces and suck out the sap for food. 
Such insects cannot be killed by applying arsenical poisons to plants, but must be treated with dusts or contact sprays which will suffocate them and corrode their tissues. Aphids, scale insects, leafhoppers and all plant bugs belong to this class.

Never spray fruit trees when in bloom. The application of lead arsenate or other arsenical poisons to trees in blossom may do much harm (1) by injuring the essential organs of the flowers, so that fruit will not set, and (2) by killing many of the bees which carry pollen from one tree to another. If all honey bees and native wild bees were killed, there would be little or no set of fruit.

Spraying versus dusting. Ten years' experiments in Connecticut show that in apple orchards, spraying gives a larger percentage of good fruit than dusting, and is less expensive. Dusting gives fairly good control of insect pests, but does not hold fungous diseases in check like spraying. Dusting has given as good results as spraying, in controlling scab and brown rot on peaches. It is probable that dusts can be used to advantage on low-growing vegetable crops, where spraying is impracticable.

Safe combinations of sprays. It is safe to mix lead arsenate with limesulfur, Bordeaux and nicotine, but in general none of these should be combined with miscible or other oils. Bordeaux mixture may be combined safely with some of the commercial miscible oils such as "Sunoco" and "Ortho Kleenup." Stabilized emulsions are required. A small amount of fish oil may be used with lead arsenate as a sticker. It is also unsafe to use soap with lead arsenate.

Beneficial insects. Some insects are considered beneficial: (1) Because they produce materials used by man, like silk and honey; (2) because they devour other insects that we call injurious; (3) because they are parasites of injurious insects and destroy them. Most of the ladybeetles, ground beetles, and checkered beetles devour other insects, as do the robber flies, Syrphid flies, lace-wings, assassin bugs, some of the soldier bugs, and mantids. Most of the Ichneumon flies, and the Tachinid flies are true parasites in the bodies of some of the larger insects. The grower should become familiar with some of these beneficial insects, and should not destroy them.

Specimens sent for identification. Insect specimens sent to the Station for identification should be enclosed in a tight strong box that will not be crushed in the mails. Such material will be examined and a report made within a few days.

\section{PRINCIPAL INSECT PESTS OF CULTIVATED PLANTS*}

\section{Abutilon}

Mealybugs, Pseudococcus sp. Abutilon plants in greenhouses are commonly infested with mealybugs. See Lantana.

Greenhouse whitefly, Trialeurodes vaporariorum. This whitefly commonly infests abutilon plants in greenhouses. See Tomato.

\section{Ageratum}

Greenhouse orthezia, Orthezia insignis. This insect is a common pest of ageratum in greenhouses. See Lantana.

Greenhouse whitefly, Trialeurodes vaporariorum. This plant in greenhouses is very susceptible to infestation by the greenhouse whitefly. See Tomato.

*Certain kinds of cultivated plants are not included in this alphabetical list because the author has no records of infestation in Connecticut. 
Mealybugs, Pseudococcus sp. Ageratum plants in greenhouses are often infested with mealybugs. See Lantana.

\section{Alfalfa}

Armyworm, Cirphis unipuncta. This insect sometimes feeds upon alfalfa. See Grass.

Clover leafhopper, Agallia sanguinolenta. This is one of the most common leafhoppers on alfalfa. See Clover.

Green clover worm, Plathypena scabra. The caterpillars of this insect feed upon alfalfa. See Bean.

Pea aphid, Illinoia pisi. This aphid sometimes infests alfalfa. See Pea.

Red Spider, Tetranychus bimaculatus. The red spider often infests alfalfa. See Phlox.

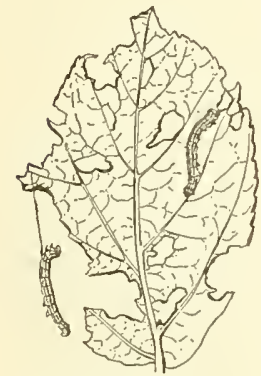

Figure 3.

Canker worms.

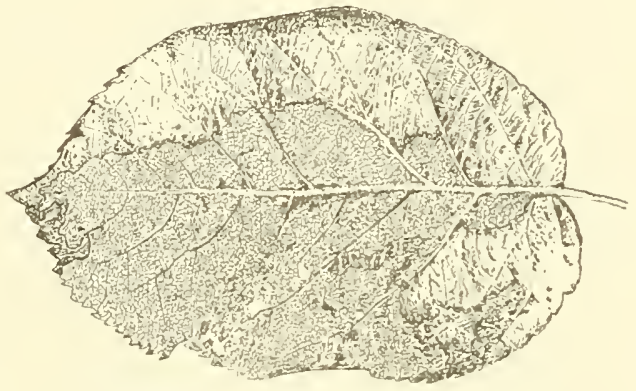

Figure 4. Work of apple and thorn skeletonizer.

\section{Apple}

Apple and thorn skeletonizer, Hemerophila pariana. This insect has three broods each season. The larvae are pale yellowish green with black spots and pale brown head. The eggs are deposited on the under side of the leaves, and the white cocoons are attached to the leaves. The moth has a wing spread of half an inch, is brown in color, usually with a purplish tinge, and with a paler cross-band of indefinite proportions on the forewings. The larvae form flat webs in which they feed on the upper leaf surface, partially skeletonizing the leaves.

Spraying with lead arsenate as is commonly practiced in orchards seems to be an effective control. (Fig. 4). See Bulletin 246, of this Station.

Apple leafhoppers. Several species of leafhoppers occur on the apple, the most abundant being the white apple leafhopper, Typhlocyba pomaria. Other species such as the rose leafhopper, Typhlocyba rosae, the potato leafhopper, Empoasca fabae, and the oblique striped leafhopper, Erythroneura obliqua are also known to infest apple. Apparently all have two generations annually in Connecticut, and $E$. fabae has three. The leafhoppers suck the sap from the leaves, causing a white-peppered appearance, or curl the terminal leaves of the new growth. When leafhoppers are extremely abundant, their excrement soils the fruit and is difficult to remove.

The most promising means of control consists in spraying with a limesulfur mixture containing nicotine sulfate at the rate of 1 part in 800 parts 
of the mixture, applied soon after the calyx spray to kill the first brood. Nicotine and soap may be applied against the second brood.

Apple maggot or railroad worm, Rhagoletis pomonella. The adult is a two-winged fly, somewhat smaller than the common house fly, and with conspicuous dark bands across the wings. The flies emerge from the ground in June and early July and the females lay eggs in punctures just beneath the skin of the ripening fruit. The maggots or larvae hatching from these eggs tunnel in the pulp of the fruit, resulting in brown spots and tunnels, and decay soon follows. Early maturing sweet and subacid varieties are particularly susceptible to injury. When fully grown the maggots go into the soil an inch or so deep and there transform to brown puparia that resemble grains of wheat. There is one generation each year, with a partial second generation in New York, the flies of the second brood appearing in September.

Late applications of lead arsenate will control this insect because the flies sip moisture from the leaves, and if the leaves are coated with poison the flies may be killed before laying eggs. For varieties ripening with McIntosh, an application about July 5 , followed by another about July 20 , is advised. In case of late maturing varieties it may be advisable to add another application about August 10, or time the two for about July 20 and August 10. Destroy drops and wild apple trees around orchard.

Brown-tail moth, Nygmia phaeorrhoea. The caterpillars of the browntail moth feed upon apple. See Pear.

Bud moth, Tmetocera ocellana. The small dark brown caterpillar with black head passes the winter in a tiny inconspicuous silken case on the bark, usually close to a bud, and feeds upon the buds and unfolding leaves. The caterpillars reach maturity in June and pupate in silk-lined cocoons formed of leaves. The moths emerge during a six weeks' period between early June and July 15, and are dark gray with a broad cream-colored band across each fore-wing, and a wing expanse of slightly over half an inch. This insect feeds upon nearly all kinds of fruit trees.

It is best controlled by a lead arsenate spray at the delayed dormant period when the leaves begin to unfold, and the treatment should be repeated if necessary.

Canker worms. The fall canker worm, Alsophila pometaria, and the spring canker worm, Paleacrita vernata, cause similar injury. The former is often very abundant locally and defoliates fruit, shade and woodland trees. The eggs of the fall canker worm are laid upon the trees in November and December, and those of the spring canker worm are laid in March and April. The caterpillars of both species are "loopers" or measuring worms that feed upon the unfolding leaves and when disturbed spin down on slender silk threads. The caterpillars of the fall canker worm have three pairs of abdominal pro-legs and those of the spring species have only two pairs. Eggs of the spring species are laid in loose masses; those of the fall species are placed on end in regular arrangement, both kinds being laid on the bark. Both kinds have wingless females that crawl up the trunks of the trees to lay their eggs and both species have slender, smooth, green or brown striped caterpillars which injure the leaves in the same way. Caterpillars become mature early in June and pupate in the soil. There is one brood annually.

Spraying the trees with lead arsenate as soon as the leaves unfold is the best means of control. Unsprayed trees may be protected by tanglefoot bands kept in a sticky condition during November, December, April and May. (Fig. 3.)

Case bearers. The cigar case bearer, Coleophora fletcherella, and the pistol case bearer, $C$. malivorella, both feed upon apple foliage. Each has one generation a year and the caterpillars live in hibernating cases from September until the following April, when they feed upon the buds and unfolding leaves, often causing considerable injury. The common names 
are descriptive of the shape of the winter cases of these two insects. The adult of each species is a small gray moth with narrow wings and a wing spread of about half an inch. Eggs are laid on the leaves during July.

The usual pre-blossom sprays of lead arsenate will control these insects.

Clover mite, Bryobia praetiosa. This mite infests apple. See Clover.

Codling moth, Carpocapsa pomonella. The codling moth, or apple worm, hatches from eggs laid upon the leaves or fruit soon after the fruit sets. The moth has a wing expanse of three-fourths of an inch, and is brown with a paler grayish area on the basal two-thirds of the fore-wings. The larva is pinkish white with dark brown head and nearly three-fourths of an inch in length when fully grown. It then makes a silk-lined cocoon in the crevices of the bark or under a loose piece of bark, where the insect passes the winter. There is a partial though not complete second generation in Connecticut. The larva tunnels in the young fruit, usually entering at the calyx and burrowing to the core. The entrance is very small, but the large worm hole is the exit tunnel. Second brood larvae often enter the fruit at the side, causing the so-called "side worm injury."

In general this insect may be controlled by thorough applications of lead arsenate, made soon after the petals fall and repeated 7 days and 14 days afterward, and about July 20, where there is injury by the second brood larvae. (Fig 9.)

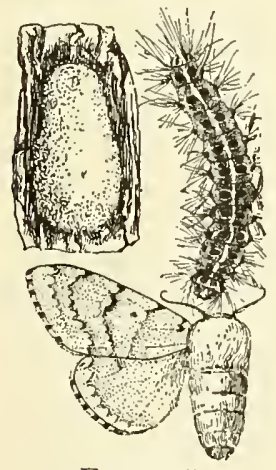

Figure 5.

Gipsy moth.

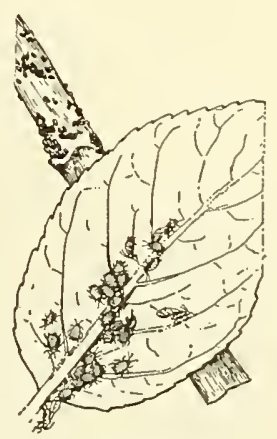

Figure 6.

Green apple aphid.

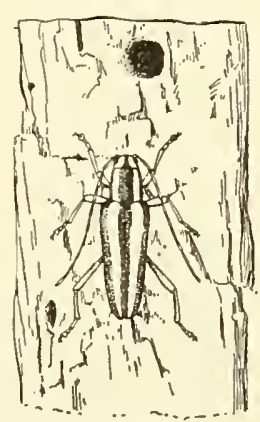

Figure 7 .

Round-headed borer.

Curculios. The grubs or larvae of both the plum curculio, Conotrachelus nenuphar (commonly), and the apple curculio, Tachypterellus quadrigibbus, (rarely) infest the fruit in Connecticut, making it gnarled and illshaped. The plum curculio is responsible for the crescent scars on apples, which mark the places where eggs are laid, and also for small deep circular pits called feeding punctures, usually near the calyx end. Both insects belong to the group called weevils or snout beetles, and each has a single generation annually. The plum curculio is the more abundant and injurious in Connecticut orchards.

Although both weevils are difficult to control, thorough and repeated applications of lead arsenate with fish oil sticker will reduce the injury to a minimum. Four applications may be necessary, as follows: pink, calyx, seven-day and two-week periods. The first is the least important. See Bulletin 301 of this Station.

Eastern tent caterpillar, Malacosoma americana. The caterpillars of this insect form nests or tents in the forks of the branches of apple and wild cherry in April and May, emerging from the nest at night and twice a day to feed upon the leaves. They become fully grown about June 1, and crawl 
about seeking a place to make their cocoons. They are then about two inches in length, black with a white stripe along the back, and many short irregular brownish stripes or markings along the side of each segment. The sides are of a bluish color, and each segment bears an oval blue spot nearly surrounded with black. The cocoon is oval, white, loosely woven of silk threads and attached by one side to a fence rail or some similar protected location. The adults of both sexes are fawn-colored with a pair of nearly parallel narrow whitish stripes extending obliquely across each front wing. The male has a wing spread of one inch, and that of the female is about one and one-half inches. There is only one brood each year and the adults emerge in late June or early July, and the females lay their eggs in a cylindrical girdle around a small twig, covering the egg-mass with a varnish-like coating to protect it. Thus the eggs remain upon the twigs until they hatch the following April.

Control measures consist of clipping off and burning the egg-clusters during the winter, destroying the nests with a caterpillar brush, and spraying the foliage with lead arsenate. (Fig. 8.) See Bulletin 177 of this Station.

European red mite, Paratetranychus pilosus. This mite infests the foliage of apple and other fruit trees, causing it to assume a rusty brown color in July and for the remainder of the season. The reddish eggs are laid on the bark of the smaller twigs and branches in September and October, and hatch the following April or May just before the buds open. The Baldwin is the variety most commonly injured.

One of the best means of control is a dormant spray of miscible oil applied preferably in March or April, but a summer application of limesulfur may be needed in severe infestations. See Bulletin 252 of this Station.

Fall webworm, Hyphantria cunea. This insect is a common pest on apple. See Pear.

Flat-headed apple tree borer, Chrysobothris femorata. This beetle often injures apple and other fruit trees, especially preferring the south side of a tree that is in an unthrifty condition. The larva tunnels in the sapwood just beneath the bark. It has a broad and thin thorax, and is called "flatheaded borer" to distinguish it from the "round-headed borer" which may be tunneling in the same tree. The adult is a coppery beetle about half an inch in length, which lays eggs in cracks or under bark scales, usually on the warmer side of the trunk or branches. The larva makes a broad, shallow, irregular tunnel just under the bark, and packs it with sawdust. Often the branch or trunk is girdled by a single borer and frequently there are several borers present.

The best control measures consist of digging out the borer; promoting the vigor of the tree; and applying a lead-arsenate-lime-sulfur wash to the unthrifty trees.

Gipsy moth, Porthetria dispar. The caterpillars feed upon the leaves of apple and other fruit trees as well as oak and other woodland trees. There is one generation each year, the moths emerging in July and the females laying oval egg-clusters of about 400 eggs each covered with buff hairs from the body of the nioth. The eggs hatch about May 1, and the cater. pillars feed during May and June. When fully grown, they are between two and three inches in length, dark gray or brown with prominent light brown hairs. Some have a light narrow stripe along the back, and all have $\mathrm{t} w 0$ rows of tubercles bearing hairs. From the head the first five pairs are blue, and the remaining six pairs are brick red. These caterpillars crawl into cavities, crevices, and other protected places and make a frail cocoon suspended by a few threads. In about two weeks the moths emerge. The females are much larger and lighter colored than the males. The female is pale buff with narrow zigzag lines across the forewings, and has a wing spread usually exceeding $t$ wo inches. The male is reddish brown with variable light gray and dark brown markings and with a wing spread of 
one to one and one-half inches. The female has a heavy body and cannot fly, but the male is a strong flier even in the day time.

The control measures consist in hunting for egg-masses in winter and soaking them with creosote, and in spraying the trees around the infestation with lead arsenate, using about 6 pounds in 100 gallons of water. The usual spray program for apple orchards will probably prevent damage. (Fig. 5.) See Bulletin 186 of this Station.

Green apple aphid, Aphis pomi. This is the most common of all green aphids on apple on Connecticut. It infests the leaves and tender shoots of terminal twigs and water sprouts. It passes the winter in the form of oval black shiny eggs on the small twigs, especially around the buds. These eggs hatch at the time the buds begin to break open. Later in the season they are seldom seen except on water sprouts. although they spend the entire season on apple and do not all migrate to other hosts like some of the other species of aphids.

The usual means of control is to give a delayed dormant spray containing nicotine sulfate and repeat the nicotine application in June. (Fig. 6.)

Green fruit worms, Xylina antennata, $X$. laticinerea and $X$. grotei. Young apples are often partially devoured by green caterpillars marked with narrow, whitish, longitudinal stripes. These caterpillars are able to climb into trees and most of the injury takes place in May and June. The moths emerge in late fall and early spring. Some of them winter as adults and the remainder as pupae in the soil.

The several lead arsenate applications before and after the blossom period should control these insects.

Japanese beetle, Popillia japonica. This beetle is very destructive to the apple crop. See Rose.

Leaf blister mite, Eriophyes pyri. This mite also infests apple. See Pear.

Leaf crumpler, Mineola indiginella. This insect has one generation each year and passes the winter in the caterpillar stage in black twisted hornlike tubes, or cases, fastened to the twigs. As soon as the buds begin to unfold, the brown caterpillars start to feed upon the leaves and sometimes the fruit is eaten. Usually several leaves are fastened together and partially eaten, this habit suggesting the common name of the insect. The caterpillars become full grown late in May and are slightly more than half an inch in length. They then pupate in their cases. In two weeks the moths emerge. They have a wing spread of between one-half and threefourths of an inch, and are brown with white markings. This insect is occasionally abundant on young trees.

The usual lead arsenate spray will control this insect.

Leaf miners. Several leaf miners injure the apple. The more important of these are the trumpet leaf miner, Tischeria malifoliella, the unspotted tentiform leaf miner, Ornix geminatella, and the ribbed cocoon maker of the apple, Bucculatrix pomifoliella. The first has two broods annually, the second has several broods, and the third has two in southern New York. The larvae of the ribbed cocoon maker are leaf miners only in their early stages and later feed openly upon the surface of the leaves. The adults of all three insects are small moths, and none are very troublesome in cultivated orchards.

Leaf rollers. The fruit tree leaf roller, Archips argyrospila, the redbanded leaf roller, Eulia velutinana, and the oblique-banded leaf roller, Cacoecia rosaceana (see Rose) all feed upon apple. The first and second have each only one generation each year and the third has two. The fruit tree leaf roller has caused serious damage in New York, and is a difficult pest to control, as the usual summer sprays are not effective. 
Dormant sprays of miscible oils or 6 to 8 per cent oil emulsions will kill the over-wintering eggs. The others may be controlled by the lead arsenate sprays commonly applied in orchard practice.

Leopard moth, Zeuzera pyrina. The larva is now quite a common borer in apple trees. See Elm.

Lesser apple worm, Enarmonia prunivora. At harvest time apples are often noticed that have been mined or tunneled just beneath the skin, often around the stem, at the calyx end or on the side where the fruit is covered by a leaf. This insect is a near relative of the codling moth, but the larva does not tunnel deeply into the fruit as does that species. The moth has a wing spread of about half an inch, and is brown with lighter and rather irregular markings.

There are two broods annually and the control measures are the same as for the codling moth, but particular emphasis should be given to the later applications.

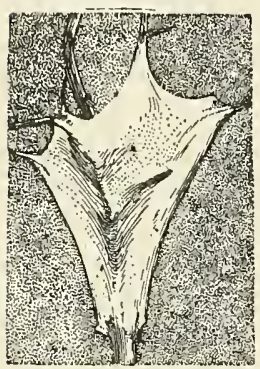

Figure 8. Nest of eastern tent caterpillar.

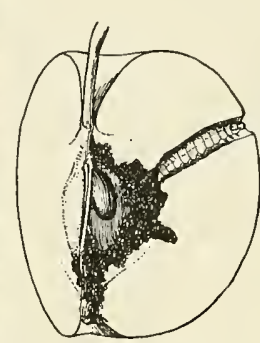

Figure 9. Codling moth

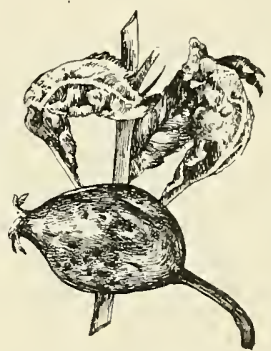

FigURE 10.

Apple red bug.

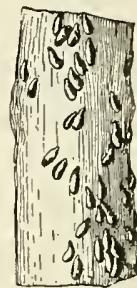

Figure 11.

Oyster-shell scale.

Oyster-shell scale, Lepidosaphes ulmi. This is a narrow, curved, pearshaped scale that is usually about the same color as the bark. It has a single generation each year, passing the winter in the egg stage. The white oval eggs are deposited beneath the female shells in late August and early September, and hatch the last week of the following May. This scale infests apple and many species of shade and woodland trees, especially ash, birch, poplar and willow, sometimes killing them.

It is seldom troublesome in sprayed orchards and is probably held in check by summer sprays of lime-sulfur. Although dormant applications of oil or lime-sulfur are said to loosen the shells so that the eggs fall out and are of some value as a control measure, probably the most effective treatment is to spray thoroughly with a good contact spray like nicotine solution just after the eggs hatch, when the young are easily killed. The first week of June is the proper time to make the application. (Fig. 11.) See Bulletins 143, p. 6 ; 151 , p. 15 ; and 292 , p. 123 , of this Station.

Palmer worm, Dichomeris ligulella. The palmer worm reaches a length of only about half an inch and is olive green in color, striped lengthwise with two lateral and two narrower dorsal, whitish stripes. It feeds upon the leaves, usually partially protected by a scanty web, but sometimes also eats into the young fruit. The moth appears in July, has a wing spread of scarcely more than half an inch, and hibernates, laying eggs on the leaves the following May. Thus there is only one annual generation.

The regular application of lead arsenate in early June will control this insect.

Red bug, Lygidea mendax. Apple foliage and fruit are often punctured by the apple red bug and become gnarled and distorted. The leaves show 
bright red dots as if sprinkled with cayenne pepper. The eggs hatch at about the time the leaves of the blossom clusters open. The bugs are rather hard to find, but their presence is first indicated by the leaf injury. Later, fruit injury may be conspicuous.

Nicotine sulfate in the spray mixture will control this insect. (Fig. 10.)

Red-humped caterpillar, Schizura concinna. In young orchards and nurseries in late summer, one often sees clusters of caterpillars devouring the foliage, each caterpillar with elevated tail and bearing a bright red head with red hump on the fourth segment. The caterpillars in each cluster have hatched from a single egg-mass. There is one annual generation, and the grayish brown moth has a wing spread of about one and onefourth inches. It emerges in June or July and lays a cluster of 50 or more eggs on the under side of a leaf near the end of a branch. When fully grown, the caterpillars are an inch or more in length. They form cocoons under trash on the ground and pupate the following spring.

The clusters of caterpillars are conspicuous and on small trees may be shaken off and crushed on the ground. They may also be killed by an application of lead arsenate.

Red spider, Tetranychus bimaculatus. This mite occasionally injures apple trees. See Phlox.

Rodent injury. Trees are sometimes girdled and severely injured by field mice and other rodents. This injury usually occurs during long periods of deep snow, or under heavy mulches of weeds and grass, when food materials are scarce. Under cover of the snow or mulch they gnaw away the bark for food.

When small or newly-set trees have been girdled they should be replaced. With larger trees it will pay to bridge-graft them to enable the sap to pass over the girdled area. For this purpose scions should be cut long enough to reach from below to above the injury. Each end of the scion should be cut in the shape of a wedge and inserted into the living bark and the cut surfaces covered with grafting wax or paraffin. The scions should be placed about two inches apart around the trunk. Sometimes sprouts around the tree may be used instead of scions. The tops of such trees should be cut back to reduce the leaf area and prevent unnecessary evaporation.

Spraying or painting the trunks with lime-sulfur and lead arsenate or wrapping them with tarred paper will tend to prevent this form of injury. See Circular 10 of this Station.

Rosy apple aphid, Anuraphis roseus. This is perhaps the most injurious of all the aphids found in apple orchards. Eggs are laid in autumn around the buds of the fruit spurs, and hatch in April when the buds unfold. The aphids are pink or purplish in color and infest the fruit clusters, causing the young apples to become stunted and irregular in shape. The future development of the apples is prevented and usually they never reach one-half their normal size. The leaves around the fruit clusters usually curl so that it is impossible or very difficult to hit the aphids with a spray. There are several generations each season.

Nicotine sulfate in the delayed dormant, prepink and pink sprays is one of the best methods of control. Late applications of miscible oils will give commercial control of this aphid.

Round-headed borer, Saperda candida. Young apple and quince trees are often seriously injured by being tunneled in the main trunk or stem near the ground. The adult is a long-horned beetle, measuring about an inch in length, gray with two conspicuous white stripes running length wise of the wing-covers and thorax. Emerging in May or June, the female lays eggs in slits that she cuts in the bark. On hatching, the young larva tunnels through the bark into the sapwood, often going below the surface of the ground to pass the winter. The second summer the borer excavates extensive galleries, sometimes girdling young trees. It is believed that 
three years are required to complete the life cycle. The round holes in the trunk are nearly the size of a pencil and are the exit holes of the adult beetles. This is a difficult insect to control, but is most troublesome in sod land near hedge rows and woodlands, and rarely causes serious damage in orchards where clean cultivation is practiced.

As to control, the borers may be cut out or killed by inserting a flexible wire, or by injecting a few drops of carbon disulfide or soluble pine oil impregnated with nicotine into the burrow and closing the opening. Various alkaline washes containing soap and crude carbolic acid as well as kerosene soap emulsions have been used as deterrents with good results, but two or three applications should be made during the period of May 1 to July 1. Wrapping the bases of the trunks for a distance of 12 to 15 inches above the ground with tarred paper, old newspaper or wire mosquito netting will protect the trees, especially if the wrapping is well away from the bark for most of its distance and tied tightly at the top. (Fig. 7.)

San Josê scale, Aspidiotus perniciosus. This scale commonly occurs on apple. See Pear.

Scurfy scale, Chionaspis furfura. This scale occasionally occurs on young apple trees. See Pear.

Tarnished plant bug, Lygus pratensis. This bug, like the red bug, punctures the developing fruit, and causes it to become dimpled and irregular, but does not make red dots like the red bug. The tarnished plant bug is an inconspicuous brown bug less than a quarter of an inch in length that injures many different kinds of cultivated plants by inserting its beak and sucking the sap. There are probably several generations each year.

Spraying with nicotine sulfate, together with clean cultivation and keeping down the weeds, is the best means of control that can now be recommended.

Tussock moths. Several tussock moth caterpillars feed upon apple. Perhaps the most important in Connecticut are the white-marked tussock moth, Hemerocampa leucostigma and the hickory tussock moth, Halisidota caryae. The former has a gray caterpillar, with black and yellow longitudinal stripes, red head, four white tufts on the back, two pencils of black hairs projecting forward from the head and one extending backward from the tail. (Fig. 47.) The female is wingless, and there are two broods each season. The frothy white egg-masses are laid on the trees near the old cocoons, and in this stage the insect passes the winter. The hickory tussock moth has only one brood each year. The caterpillar is covered with white hairs with a stripe of black hairs lengthwise along the back. (Fig. 44.)

The lead arsenate spray will prevent defoliation.

Woolly apple aphid, Eriosoma lanigera. This insect migrates from elm to apple, where it is noticeable around scars and wounds as a bluish white cottony growth. This is really the wax secretion from the bodies of all the aphids in the colony. The presence of these aphids prevents the wounds from healing, and causes swellings or galls to form on twigs, branches and roots. The small feeding roots are sometimes wholly destroyed by a heavy root infestation.

As a control measure, nicotine sulfate and soap may be used freely on the branches, and in the soil where the aphids are known to be present. An emulsion containing 6 per cent of pine tar creosote should be applied.

Yellow-necked caterpillar, Datana ministra. Like the red-humped caterpillar, the yellow-necked caterpillar feeds in clusters in August and September near the ends of the branches of young orchard and nursery trees. There is a single annual generation. The insect hibernates as a pupa in the soil. The moth emerges in June and July and lays eggs on the leaves. The caterpillars are striped lengthwise with narrow yellow and black stripes, and bear long whitish hairs. When disturbed they elevate both heads and tails. 
Like the red-humped caterpillars, the yellow-necked caterpillars may be shaken off and crushed or killed by spraying with lead arsenate

\section{Araucaria}

Mealybug, Pseudococcus citri. Whitish, dusty appearing bugs in the axils of leaves and branches suck the sap and often cause considerable injury.

Spray with an impregnated oil emulsion or pyrethrum-soap. In greenhouses that are fumigated occasionally with hydrocyanic acid gas the mealybug is held in check.

\section{Arborvitae}

Arborvitae leaf miner, Argyresthia thuiella. The small greenish larva of this moth is a miner in the narrow leaflets of arborvitae, and passes the winter in the mines. The injured leaves turn brown. The light gray moths emerge the last week of May and the first part of June, and lay eggs on the leaves. These eggs hatch about June 20 and the larvae begin mining the leaves. There is one generation each year. Shaded plants are more heavily infested.

Though control measures are of somewhat questionable value, it is believed that thorough applications of nicotine solution and soap, or of fish-oil emulsion, about June 1, may kill some of the eggs and larvae as well as some of the moths. See Rept. 1921, p. 157; and Bul. 292, p. 161, of this Station.

Arborvitae soft scale, Lecanium fletcheri. This is a small brown hemispherical scale occurring on arborvitae. It has been found in Connecticut in a few localities.

A spray of nicotine solution and soap is recommended as a means of control.

Red cedar bark beetle, Phloeosinus dentatus. This insect also injures arborvitae. See Red Cedar.

Spruce mite, Paratetranychus ununguis. This mite injures arborvitae. See Spruce.

\section{Ash}

Ash flower gall, Eriophyes fraxiniflora. This mite causes a distortion of the staminate flowers of white ash, forming bunches or masses from onefourth to three-fourths inch in diameter. These masses finally dry and remain on the tree over the following winter.

Dormant sprays of miscible oil are said to prevent this development.

Ash sawfly, Tomostethus bardus. Occasionally the leaves of white and green ash are devoured in May and June by greenish white sawfly larvae, which reach a length of nearly three-quarters of an inch. The color is pale greenish white, with a darker green median stripe, and with black head and legs.

Spraying with lead arsenate will prevent defoliation.

Carpenter worm, Prionoxystus robiniae. The larva of this insect is a destructive borer in ash. See Locust.

Oyster-shell scale, Lepidosaphes ulmi. This scale often kills young sprouts and seedlings. See Apple.

\section{Asparagus}

Asparagus miner, Agromyza simplex. This insect mines or tunnels near the base of the stem and just beneath the epidermis. Some of the mines 
start a foot or more above the soil and the miners work downward, often beneath the surface. The adult is a two-winged fly that emerges during the first week in June, and there are two generations each season. The insect passes the winter in the burrow, in the form of a pupa resembling a flax seed.

This is not a destructive insect and the only control advised is to burn the stalks in late fall to kill the over-wintering pupae.

Common asparagus beetle, Crioceris asparagi. This is a bluish black beetle with three whitish spots and an orange outer margin and tip on each wing-cover. The thorax is reddish and usually bears two black spots. This beetle is about one-fourth of an inch in length and hibernates under rubbish, bark of trees, or similar situations where it can find shelter. Emerging from winter quarters at the time the shoots appear, the beetles eat the tender shoots, often causing considerable injury. The females lay eggs that are fastened vertically upon the shoots, but later in the season place them upon the leaves and flower stems. The grubs that hatch from the eggs are gray with black legs and head, and feed voraciously upon the leaves, the epidermis of the stalks, and damage the shoots near the end of the cutting season.

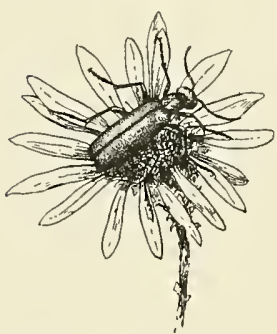

Figure 12. B l a c k blister beetle on aster.

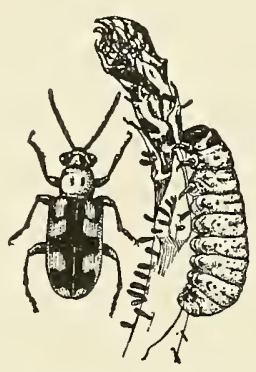

Figure 13. Asparagus beetle.

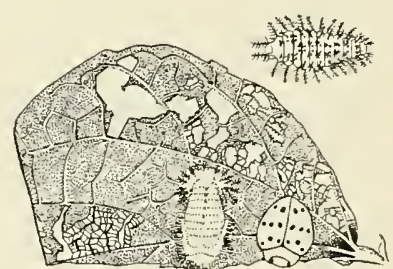

Figure 14.

Mexican bean beetle.

New plantations must be protected, as defoliation weakens the plants. Some growers practice clean cutting as long as the cutting season lasts, then spray the plants with lead arsenate and caseinate of lime. Other growers allow a few plants to grow as trap plants to be destroyed later. The grubs may be killed in a small bed by spraying with nicotine (1-400) with soap, and doubtless with pyrethrum-soap. (Fig. 13.)

Spotted asparagus beetle, Crioceris duodecimpunctata. The spotted asparagus beetle is slightly larger than the common asparagus beetle, is reddish brown or orange in color, and has six black spots on each wingcover. The beetles feed on the tender shoots with the common asparagus beetles, but the eggs are not laid until about the time the plants begin to blossom. The eggs are deposited singly on the leaves and fastened horizontally to them. The larvae or grubs of this insect feed almost entirely in the berries of the fruiting plants. There are two broods in the northern states and the adult beetles live through the winter in protected places.

The control methods practiced in case of the common asparagus beetle will also control the spotted species.

\section{Aster}

Blister beetles. Aster flowers are frequently devoured by the black blister beetle, Epicauta pennsylvanica (Fig. 12), occasionally by the margined blister beetle, Epicauta marginata, and rarely by two or three other 
species, the gray blister beetle, Epicauta cinerea, and the ash-gray blister beetle, Macrobasis unicolor.

In case these blister beetles feed upon the leaves, a spray of lead arsenate will prove effective, although it may be necessary to repeat the application because the beetles that are killed may soon be replaced by others. Such a poison is objectionable on flowers, and where grown for cutting it may be advisable to cover the plants with mosquito netting to keep off the beetles, Another remedy is to jar them from the plants into a pan of water with kerosene oil on the surface.

Leaf miners. The leaves of aster are sometimes infested by miners that make narrow serpentine mines, Phytomyza albiceps; or blotch mines, Agromyza platyptera var. coronata, and A gromyza posticata, all two-winged flies. What appears to be the first species was collected in Connecticut in 1931.

Little is known about these leaf miners or how to control them. Possibly a spray of nicotine solution and soap may prove effective.

Root aphids. The roots of asters and other plants are often infested with mealy, white, wingless aphids of the genera Geoica and Forda. The corn root aphid, Anuraphis maidi-radicis has also been taken from aster roots in Connecticut.

Little is known regarding the life history of these root aphids or how to control them, but undoubtedly some of them may be killed by making small holes in the soil close to the roots of the plant and filling them with carbon đisulfide or with nicotine solution and soap.

Stalk borer, Papaipema nitela. This insect is a borer in aster. See Dahlia.

\section{Azalea}

Azalea bark scale, Eriococcus azaleae. Azalea plants growing out-ofdoors are frequently infested with the white cottony or woolly masses of this insect fastened to the twigs, usually in the axils of the branches of close to the buds. Both sexes are enclosed in a felt-like sac.

Although records of control are lacking, it is probable that a thorough spraying with nicotine and soap, with pyrethrum-soap, or with a white oil emulsion will prove effective.

Azalea whitefly, Aleyrodes azaleae. This insect infests Azalea indica in greenhouses and was brought into Connecticut many times in 1913, 1914, and 1915 on azaleas imported from Belgium. It is not definitely known to have become established in this country.

It can doubtless be controlled by fumigating the greenhouse with hydrocyanic acid gas, and by underspraying the foliage with nicotine and soap or pyrethrum-soap.

Lacebugs. Both the azalea lacebug, Stephanitis pyrioides, and the rhododendron lacebug, $S$. rhododendri, may injure azalea by sucking the juice from the under side of the leaves.

To control these insects, a contact spray such as nicotine solution and soap should be directed against the under surface of the leaves.

Rhododendron borer, Sesia rhododendri. This insect is also a borer in azalea. See Rhododendron.

\section{Barberry}

Barberry aphid, Liosomaphis berberidis. This small yellowish green aphid is often very abundant on the leaves and tender shoots, and sucks the sap.

A thorough spraying with nicotine solution and soap is a good remedy. 
Barberry webworm, Omphalocera dentosa. Blackish white-spotted caterpillars occasionally make webs on the twigs and devour the leaves. The adult is a grayish brown moth with wing spread of about two inches, and belongs to the family Pyralidae.

Spraying with lead arsenate will prevent defoliation.

\section{Barley}

Aphids. Several species of aphids have been recorded from barley and some of them are known to occur in Connecticut. These are Rophalosiphum prunifoliae, Myzus persicae, Macrosiphum granarium and probably Toxoptera graminum.

Control measures other than cutting the crop or burning over certain badly infested areas are not recommended.

Armyworm, Cirphis unipuncta. This insect feeds upon barley. See Grass.

\section{Bean}

Bean aphid, Aphis rumicis. This black aphid is common on bean and a great many other plants. Like certain other species of aphids, there are many generations annually. Most of them are born alive, but in the autumn eggs are laid on various shrubs to carry the species through the winter.

It is not often that control measures are necessary but the aphids can be killed by a thorough spraying of the under surface of the leaves with nicotine sulfate and soap, or by dusting with nicotine dust.

Bean leaf beetle, Cerotoma trifurcata. In occasional seasons this beetle causes some injury by feeding upon the leaves. It is about one-fifth of an inch long and varies greatly in color and markings. The ground color varies from pale buff to dull red, with two black rectangular spots on each wing-cover near the inner margins; there is also a small triangular spot at the base and another at the apex of each wing-cover.

The remedy is to spray or dust with magnesium arsenate or barium fluosilicate as used for the control of the Mexican bean beetle.

Bean leafhopper, Empoasca fabae. Beans are occasionally injured by leafhoppers, perhaps the most common species being the one mentioned above. This leafhopper is pale green with wings and wing-covers transparent and colorless. It injures the leaves by sucking sap from the under side, giving the leaves a white peppered appearance or it curls the young leaves.

Probably a thorough spraying with nicotine sulfate at the rate of 1 part in 800 parts of water, or adding it to the magnesium arsenate mixture when used to control the Mexican bean beetle, will prove effective.

Bean weevil, Acanthoscelides obtectus. The adult beetles lay eggs in the pods in the field and the grubs feed inside the seeds or beans and emerge after the beans have been placed in storage. They will continue to breed in the dried seeds, rendering them unfit for food or for planting. There are six annual generations in the District of Columbia and a smaller number in the northern states. The beetle is about one-eighth of an inch long, brown, with wing-covers striped lengthwise with light brown and gray and mottled with darker spots.

Weevils in beans may be killed by storing the beans packed in air-slaked lime, by fumigating with carbon disulfide, or by heating in an oven for an hour at a temperature between $120^{\circ}$ and $150^{\circ} \mathrm{F}$. (Fig. 15.)

Cutworms. See Tomato.

European corn borer, Pyrausta nubilalis. The larvae are borers in bean stems and pods. See Corn. 
Green clover worm, Plathypena scabra. In certain seasons bean plants are seriously injured by green wriggling caterpillars an inch long that riddle the leaves. In color the worms are light green and they are striped longitudinally with darker green and fine white or cream-colored lines. The head is pale green, shining and hairy. The adult moth has a wing expanse of from one to one-and-one-half inches, dark purplish brown, with fore-wings more or less distinctly marked or mottled with bluish gray, brown and black. The rear wings are very broad, smoky brown, and without markings.

String beans may be protected by spraying with nicotine sulfate and soap, or by dusting them with air-slaked lime. Shell beans may be sprayed with magnesium arsenate or dusted with barium fluosilicate as for the control of the Mexican bean beetle.

Green soldier bug, Acrosternum hilaris. This bug is between one-half and three-fourths of an inch in length, oval in shape and bright green with yellow or reddish margin. This bug occasionally injures beans and various other plants by sucking sap from the shoots and leaves, but probably no control measures will be necessary. If so, a spray of nicotine solution and soap should be effective.

Light-loving grapevine beetle, Pachystethus lucicola. This beetle is about one-fourth of an inch in length and usually light brown in color without markings, but a certain proportion of the individuals are black. In 1931, this insect was unusually abundant and ate holes through bean leaves in many plantations. There is one annual generation.

The treatment required for the control of the Mexican bean beetle will also control this insect.

Mexican bean beetle, Epilachna corrupta. At present this is the most destructive of all insects feeding on beans in Connecticut. It is a ladybeetle about one-fourth of an inch in length, broadly oval, and pale brown with eight small black spots arranged in three transverse rows on each wing-cover. This insect first appeared in Connecticut in 1929 and in 1931 caused damage in nearly all bean plantations throughout the state, although more severe damage occurred in Fairfield and New Haven Counties than elsewhere. There are two generations each season and the winter is passed by the adults in protected situations. The first brood of larvae feed upon the leaves the latter half of June and first part of July and those of the second brood feed during August. Adults also do some feeding on the leaves.

Control measures consist in spraying or dusting shell beans with magnesium arsenate or barium fluosilicate. String beans may be sprayed with pyrethrum-soap. Lead arsenate and calcium arsenate may injure the foliage. (Fig. 14). See Bulletin 332 of this Station.

Potato flea beetle, Epitrix cucumeris. This flea beetle feeds upon bean. See Potato.

Seed corn maggot, Hylemyia cilicrura. The maggots often infest seed beans after planting. See Corn.

Spotted cucumber beetle, Diabrotica duodecimpunctata. This beetle often feeds upon beans. See Cucumber.

Striped cucumber beetle, Diabrotica vittata. This beetle feeds to some extent on beans. See Cucumber.

Wireworms. See Tobacco.

\section{Beebalm}

Aphids. Beebalm is rarely infested by an aphid, Aphis monardat. which may be controlled by spraying with nicotine sulfate and soap.

Stalk borer, Papaipema nitela. The stalk borer occasionally tunnels in beebalm. See Dahlia. 


\section{Beech}

Beech woolly aphid, Phyllaphis fagi. This aphid infests the under surface of the leaves of the European beech and its purple leaf variety, but is not found on the white or American beech. It secretes white wax and infested leaves appear as though small tufts of cotton were fastened to them.

Nicotine solution and soap sprayed against the under surface of the leaves is a good method of control.

Saddled prominent, Heterocampa guttivitta. Occasional outbreaks of this insect have been responsible for widespread defoliation of shade and forest trees in the mountain regions of New England and New York in 1907 and 1908, 1917 and 1918, and in 1930 and 1931, especially of beech, birch and maple trees. The eggs are laid on the leaves early in July, hatch in nine days, and the caterpillars become fully grown in about five weeks, when they pupate and hibernate in the ground. There appears to be only one brood each year. The mature larva is about one and one-half inches in length with great variation in color and markings. Some are light yellowish green and some are nearly purple. Many have a purple mark or saddle near the center of the body, but some have no saddle marks and there are all intergradations. The moth has a wing spread of one and one-half to two inches and is olive gray in color without prominent markings.

Choice shade trees may be protected by a spray of lead arsenate.

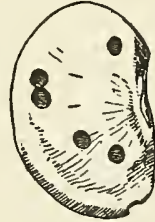

FIGURE 15.

Exit holes of bean weevil.

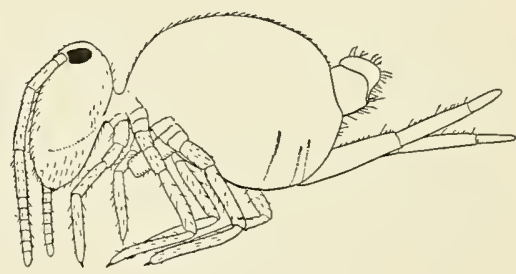

Figure 16.

Garden springtail.

\section{Beet}

Bean aphid, Aphis rumicis. This aphid also infests beet. See Bean.

Blister beetles. See Aster.

European corn borer, Pyrausta nubilalis. This insect often infests beet tops. See Corn.

Flea beetles. Several species of flea beetles that occur in Connecticut are known to feed upon beet, the more important being the potato flea beetle, Epitrix cucumeris; the pale-striped flea beetle, Systena taeniata blanda; the red-headed flea beetle, Systena frontalis; and the smart-weed flea beetle, Systena hudsonias. Most of the flea beetle injury occurs on the young plants. After the plants reach a certain size they are not injured. It is rarely that any control measures will be necessary.

Where severe injury is threatened, perhaps a spray of calcium arsenate is best. In the home garden a spray of nicotine sulfate and soap has been shown to be effective.

Garden springtail, Sminthurus hortensis. Small seedlings of many varieties of vegetables are injured and often killed by minute jumping insects that eat small holes in the leaves. These insects have no wings, but are equipped with forked tail-like appendages, by means of which they are 
able to throw themselves into the air. They are usually found only on small plants near the surface of the soil.

Spraying with nicotine solution and soap, or dusting with a nicotine dust will prevent further injury. (Fig. 16.)

Spinach leaf miner, Pegomyia hyoscyami. This leaf miner often infests beet. See Spinach.

\section{Begonia}

Aphids. The melon aphid and probably other species occasionally infest Begonia.

A forceful spray of water from the hose will dislodge them, or they may be killed by spraying with nicotine sulfate and soap.

Mealybug, Pseudococcus sp. See Araucaria.

\section{Bellflower}

Garden slugs. Garden slugs are very fond of young campanula plants. See Lettuce.

\section{Birch}

Aphids. Birch trees are subject to infestation by many species of aphids. Only two of them can be mentioned here. Euceraphis deducta with considerable wax secretion swarmed from birch-covered fields into Connecticut cities and towns in 1923, and Calaphis betulaecolens without much wax secretion swarmed in New Haven in 1919 and 1923. These aphids are often extremely abundant on birch.

Nicotine sulfate and soap applied as a spray is perhaps the best method of control.

Birch leaf skeletonizer, Bucculatrix canadensisella. This insect has periods of great abundance about every 11 years when it defoliates white birch trees in the northern states. There is one generation each year. The adults emerge from the cocoons in June and July and the females lay eggs on birch leaves. The eggs hatch in 15 days and the larvae mine in the leaves for the first three instars, or nearly a month; then for the last two instars, or about two weeks, they feed externally on the under surface of the leaves, skeletonizing them. The larvae complete feeding the latter part of September and spin cocoons under fallen leaves and other debris on the ground where they pass the winter. Birches injured are the gray birch, paper birch, yellow birch, and European white birch.

Spraying with lead arsenate about the middle of August will protect the trees against injury. Bulletin 288 of this Station is devoted to this insect.

Birch sawfly, Croesus latitarsus. The larvae of this insect are occasionally found feeding around the margin of a birch leaf. As a rule they are all headed the same way and the distal portion of each body is elevated. The adult is a four-winged fly with blue-black body and white markings on the legs.

Control measures will not be necessary except in rare instances when young ornamental birch trees are being injured. Spraying with lead arsenate will prove effective.

Bronze birch borer, A grilus anxius. This insect is the most destructive to the European white birch and its cut-leaf variety of any insect occurring in Connecticut. The upper portion of the tree is usually first infested, and shows spiral ridges on the bark of the branches. In some cases, however, trees have become infested clear down to the base of the trunk. The beetles emerge late in May or early in June through semicircular exit holes. The eggs are laid in crevices in the bark during June, and apparently 
there is only one generation each year. The nearly mature grubs form cells in the burrows in which they hibernate, and in the spring transform to pupae.

Control measures are difficult and of questionable value. It is said that the adult beetles feed somewhat upon the foliage soon after emergence and that spraying the trees late in May will kill some of them. Certain tree experts claim that at the beginning, by abundant applications of fertilizer and water to induce vigorous growth, the tree may be saved. Others recommend cutting off and burning the branches first infested. However, if a tree has been severely injured, it should be removed and burned before May 1, to prevent the emergence of the beetles. (Fig. 17.)

Gipsy moth, Porthetria dispar. The caterpillars of this insect feed upon birch. See Apple.

Imported birch leaf miner, Fenusa pumila. Leaves of gray birch, paper birch, and European white birch and its cut-leaf variety, especially the tender terminal leaves on young trees and sprouts are commonly injured by the larvae of this insect and turn brown. The tender leaves at the tops

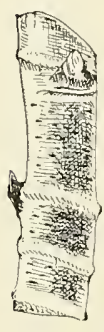

Work of bronze birch borer.

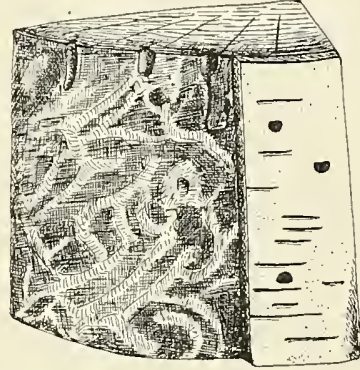

Figure 17.

of tall trees are less severely injured. The adult is a small black sawfly having three annual generations and in some seasons a partial fourth. The insect will not lay eggs in the older and hardened leaves.

On choice lawn trees this insect may be controlled by spraying with nicotine sulfate, 1 part in 800 parts water without soap. Both upper and under surfaces of the leaves should be covered. Two applications should be made for the first generation, the first between May 20 and May 25 and the second a week afterward. Three similar treatments at weekly intervals beginning about July 3 should be directed against the second brood. (Fig. 18.)

Leopard moth, Zeuzera pyrina. The larvae are occasional borers in birch. See Elm.

Oyster-shell scale, Lepidosaphes ulmi. This is a common scale on young birch sprouts. See Apple.

Tussock moths, several species. See Apple, Hickory and Horsechestnut.

\section{Bittersweet}

Aphids. The bean aphid, Aphis rumicis; the spiraea aphid, Aphis spiraecola; and the pea aphid, Illinoia pisi, all infest the bittersweet. 
Spraying with nicotine sulfate and soap will control them.

Euonymus scale, Chionaspis euonymi. Bittersweet often becomes infested by the euonymus scale. See Euonymus.

Two-marked treehopper, Enchenopa binotata. This grotesque little insect has a curious projection on the thorax that makes it resemble in profile a bird. When several individuals walk along the stem one behind another, one thinks of a flock of geese marching single file. The eggs are laid in white frothy masses on the twigs, and young and adults are present in July and August. The adults are dark brown with two narrow white spots on the ridge of the back.

Ordinarily control measures are not needed, but probably the young at least may be killed by a spray of nicotine sulfate and soap.

\section{Blackberry}

Blackberry leaf miner, Metallus rubi. The larva of this sawfly is a miner in the leaves of blackberry and dewberry, and the insect has two generations each year. Eggs are laid in blisters on the nnder side of the leaves in May and early June for the first brood, and in August for the second brood. The larvae mine the margins and distal extremity of the leaf blades, making blotch mines which are usually confluent when several miners are at work in the same leaf. The adult is a nearly black fourwinged fly about one-sixth of an inch in length.

Although a satisfactory control for this insect has not been worked out, there is a probability that the larvae may be killed by spraying the leaves with nicotine sulfate, 1 part in 800 parts water, with soap added as a spreader.

Blackberry psyllid, Trioza tripunctata. This jumping plant louse is a native of the wild blackberry, but occasionally it injures cultivated plants. The adult is about one-sixth of an inch long, yellowish brown, and each wing is marked by three yellowish brown bands. The adults live through the winter in protected places, appear on the plants soon after growth begins, and lay eggs in the pubescence of leaf-stems and tender shoots. Both nymphs and adults puncture the stems and leaves causing a stunted and distorted growth sometimes called galls. The nymphs become fully grown late in the season and the adults hibernate. There is one annual generation.

Control measures have not been worked out and probably will seldom be necessary. Probably spraying with nicotine solution and soap will prove effective.

Blackberry sawfly, Pamphilius dentatus. Occasionally in Connecticut blackberry leaves are devoured by the larvae of this insect. The adults appear the latter half of May, and the females lay white oval eggs placed end to end and fastened by the side to the larger veins on the under side of the leaves. The larvae roll the leaves, fasten them by a web, and feed inside the web. They become fully grown the first half of July and are then about three-fourths of an inch in length and of a bluish green color. They then enter the soil to remain until the emergence of the adults the following May.

Spraying with lead arsenate will prevent defoliation by this insect.

European fruit lecanium, Lecanium corni. This scale often infests blackberry. See Plum.

Raspberry root borer, Bembecia marginata. This insect is also a borer in blackberry roots. See Raspberry.

Red-necked cane borer, Agrilus ruficollis. Swellings from one to three inches long are often made by this insect on the new canes. The adult is one-third of an inch long, with blue-black wing-covers and reddish or copper-colored thorax. There is only one annual generation and the 
beetles, though present on the bushes from May to August, are most abundant in June. The female lays eggs in the bark near a leaf stalk. Each larva burrows upward in the sapwood and goes around the twig several times in a spiral course forming swellings or galls. The larva hibernates in the pith, where it completes its growth and pupates the following spring.

When the annual pruning takes place, all infested canes should be removed and burned.

Rose Scale, Aulacaspis rosae. This scale infests rose and blackberry. See Rose.

\section{Blueberry}

Apple maggot, Rhagoletis pomonella. The apple maggot commonly infests blueberry and huckleberry. See Apple.

Blueberry flea beetle, Haltica torquata. This flea beetle injures blueberry bushes in Maine by feeding upon the leaves. It occurs in Connecticut, but apparently is not very common here. It has a single generation each year, and hibernates in the egg stage near the ground. Eggs hatch the latter part of May and the young grubs feed upon the opening buds, destroying and weakening many of them. Later the grubs feed upon the leaves. By the last of June all have pupated in the ground, and the adult beetles begin to emerge July 1 and continue for some time. The adults are coppery bronze in color, nearly one-fourth of an inch in length, and feed upon the margins of the leaves.

This insect may be controlled by spraying with lead arsenate.

Blueberry gall, Hemadas nubilipennis. A tiny four-winged fly is responsible for the hard reniform twig galls on low blueberry. The galls are green at first, but later turn reddish and finally brown. The insects emerge in the spring.

Control measures are not known.

Blueberry spittlebug, Clastoptera proteus. This insect causes the frothmasses or "spittle" on the twigs of blueberry and huckleberry. The eggs are laid in the bark of the outer twigs. A nymph is present in the center of each spittle mass.

In case any method of control is needed, spraying with nicotine sulfate probably will prove effective.

Oyster-shell scale, Lepidosaphes ulmi. This scale occurs on blueberry and huckleberry. See Apple.

Variegated cutworm, Lycophotia margaritosa saucia. The caterpillars of this insect feed upon the foliage. See Carnation.

\section{Boxwood}

Box leaf miner, Monarthropalpus buxi. This is the most serious insect pest of box in Connecticut. The adult, which is a two-winged fly, lays eggs in the leaves in June. The larvae live in the leaves between the upper and lower epidermal layers, usually several in each leaf, but they do not devour the green tissue as do most leaf miners. Certain whitish spots with leaves somewhat blistered and distorted are the only external indication that the leaves are infested.

The remedy is to spray the plants with a cheap molasses, one part in four parts of water with nicotine sulfate added at the rate of 1 part in 500 parts of the spray material. The first application should be made when the adults first begin to emerge late in May, and the plants should be kept covered for about three weeks. One spray each week will answer in fair weather, but an application should be made after each rain.

Box psyllids, Psyllia buxi and Spanioneura fonscolombii. These jumping plant lice, in both adult and nymphal stages, infest box and suck the 
sap. Little is known of their life cycles in Connecticut, but if either or both should become injuriously abundant, perhaps the best method of control would be to spray the plants with nicotine sulfate and soap.

Oyster-shell scale, Lepidosaphes ulmi. This scale sometimes occurs on box. See Apple.

\section{Broccoli}

In general, the insects that injure cabbage also feed upon broccoli. See Cabbage.

\section{Brussels Sprouts}

The common insect pests of cabbage also feed upon brussels sprouts. See Cabbage.

\section{Butternut}

Oyster-shell scale, Lepidosaphes ulmi. This scale commonly infests butternut. See Apple.

Walnut caterpillar, Datana integerrima. This caterpillar feeds upon butternut. See Walnut.

Walnut weevil, Conotrachelus juglandis. This weevil infests butternut. See Walnut.

\section{Cabbage}

Cabbage aphid, Brevicoryne brassicae. This whitish powdery or mealy aphid occurs in colonies on the leaves causing them to curl more or less and prevents the plant from heading. This aphid sucks the sap, and 16 generations have been known to develop from April 1 to October 1. Most of the aphids are wingless, but in case of overcrowding or if something happens to the host plant, winged individuals develop and the aphids fly to some other plant. In the North, the insect passes the winter in the form of black, glossy eggs on the leaves and stems of the old plants remaining in the field, but in the South the aphids survive tlie winter. dust.

The best method of control is to dust the plants heavily with a nicotine

Cabbage looper, Autographa brassicae. This light-green caterpillar is striped lengthwise with light and darker green and loops when it crawls. It is narrowest at the head, increasing to nearly twice this thickness at the posterior extremity. It is nearly smooth with a few scattered hairs, and reaches a length of about one and one-fourth inches when fully grown. It is of ten found feeding with the more hairy and darker green cabbage worm, especially late in the season. The cabbage looper eats holes deep into the heads. There are two broods each season and the moth has a wing spread of about one and one-half inches. The fore-wings are grayish brown marked with white.

The methods used in controlling the cabbage worm will control this species, but on account of its habit of eating into the heads, arsenical poisons should not be used on headed plants injured by the cabbage looper. Pyrethrum-soap may be used in such cases. (Fig. 21.)

Cabbage maggot, Iylemyia brassicae. This insect infests the stems of early-set cabbage and cauliflower plants, as well as the fleshy roots of radish and turnip. As a rule, late planted cabbage is not injured, but late radish and turnip may be ruined by this insect. The maggots infest the stems just below the surface of the soil and infested cabbage and cauli- 
flower plants usually wilt and die without forming heads. The small flies appear about the middle of May, and the females lay eggs on the surface of the soil near the stem of the plant. There are three broods each year, and the insect hibernates in the pupa stage in the soil. The adults are slender gray flies, generally resembling the house fly, only smaller.

This insect may be controlled by placing tarred paper disks around the stems of the plants when set, or by applying half a cupful of calomel at the rate of 1 ounce in 10 gallons of water, or a 4 per cent calomel gypsum dust around the plants on the surface of the soil. (Fig. 19.)

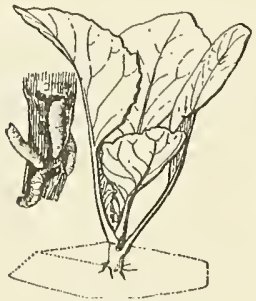

Figure 19.

Cabbage maggot.

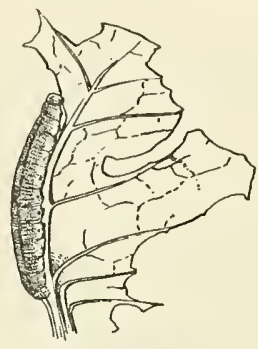

Figure 20.

Cabbage worm.

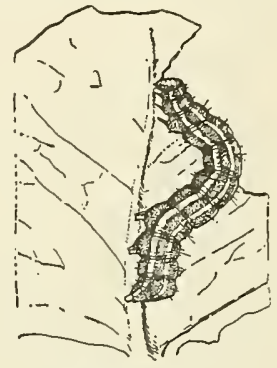

Figure 21.

Cabbage worm, Pieris rapae. The cabbage worm is bright green in color, covered with rather closely-set short hairs, and feeds upon the outer leaves all through the season. It is the larva of the white butterfly that is so common about the field. There are three annual generations in New England. The yellow eggs are laid singly on the under leaf surface and placed on end. The mature caterpillar is about an inch in length. The butterfly has a wing spread of about one and three-fourths inches. The wings are white with a tinge of sulfur yellow. The tips of the fore-wings are gray and the male has a black discal spot on each fore-wing; the female has two spots. Both sexes have a black spot on the front margin of each rear wing. The chrysalis is suspended under fence rails, the lower edge of clapboards, and the like.

The accepted method of control is to spray or dust with lead arsenate. (Fig. 20.)

Cutworms. See Tomato.

Diamond-back moth, Plutella maculipennis. Although usually a minor pest, at times this insect causes considerable injury to cabbage and allied plants by eating small holes through the outer leaves. The larvae are pale green and only about one-fourth of an inch in length when full grown. They are very active, and when disturbed wriggle and drop to the ground. The pupa is enclosed in an open-work net attached to the leaves and in this stage the insect hibernates. The adult is a small gray moth with light yellow rear margins on the fore wings. It has a wing spread of five-eighths of an inch.

The usual applications of lead arsenate will control this insect.

Wireworms. See Tobacco.

Zebra caterpillar, Mamestra picta. This black caterpillar with bright yellow markings is common in the garden and feeds upon nearly all kinds of vegetables as well as many flowering plants. It is about two inches long when full grown. The moth is reddish brown without prominent markings, and the rear wings are nearly white with brown margins. There are two annual generations.

Spraying with lead arsenate is the best remedy. 


\section{Cactus}

Cactus scale, Diaspis echinocacti cacti. This light gray circular scale infests certain species and varieties of cactus under cultivation.

Little is known about its life cycle, but wherever greenhouses are fumigated with hydrocyanic acid gas this insect, if present, will be killed. It can doubtless be held in subjection by spraying the plants with nicotine sulfate and soap.

\section{Calendula}

Blister beetles. See Aster.

\section{Calla Lily}

Aphids. Certain species of aphids are occasionally troublesome on the leaves of Calla lily.

A good remedy is to spray with nicotine soap solution.

Yellow woolly bear, Diacrisia virginica. The caterpillars feed upon calla leaves. See Verbena.

\section{Camellia}

Camellia scale, Fiorinia fioriniae. This yellowish brown scale with white margins, a distinct dorsal carina, and nearly parallel sides, infests a great many different plants in the greenhouse, including camellia.

It can be controlled by the usual nicotine sprays.

Fuller's rose beetle, Asynonychus godmani. See Rose.

Mealybug, Pseudococcus sp. See Lantana.

Soft scale, Coccus hesperidum. See Fern.

\section{Canna}

Greenhouse leaf tier, Phlyctaenia rubigalis. This insect occasionally injures canna. See Celery.

Japanese beetle, Popillia japonica. The adult beetles feed upon the blossoms. See Rose.

\section{Carnation}

Aphid or green fly. Several species of aphids infest the young leaves and buds, suck the sap, and are often troublesome in greenhouses.

In such cases, the usual remedy is to fumigate the greenhouse either with hydrocyanic acid gas or by burning tobacco stems or leaves. Spraying with nicotine sulfate and soap will also kill those aphids that are hit by the spray.

Red spider, Tetranychus bimaculatus. This is an important pest of carnations. See Phlox.

Variegated cutworm, Lycophotia margaritosa saucia. Larvae of the variegated cutworm frequently infest greenhouses in the fall and are responsible for considerable injury. They climb the stems and eat holes into carnation buds, and feed upon a great many other plants. The moth has a wing spread of between one and one-half and two inches, with brownish gray fore-wings. The caterpillar is light brown mottled with darker brown. Normally there are two annual generations out-of-doors, but there may be more in the greenhouse. 
Some of the control measures are: hand picking, trapping the caterpillars under pieces of board, and the use of poisoned bait.

\section{Carrot}

Aphids. The bean aphid, Aphis rumicis, the spinach aphid, Myzus persicae, and the corn root aphid, A nuraphis maidi-radicis, all occasionally infest carrot.

Probably nicotine and soap or pyrethrum-soap will prove an effective control.

Carrot rust fly, Psila rosae. This slender dark-green fly lays eggs in the soil close to the plant late in May and the young maggots work their way downward along the root and begin feeding at the tip of the tap root. Later the entire root may be tunneled through and through, and the burrows are rusty brown in color, which explains the name. The maggots pupate in the soil and there are two generations of the fly each season. The first brood maggots feed during June and the second brood during August. Carrot, parsnip and celery are injured.

Glasgow in New York, found that seed planted in June escaped the first brood infestation and could be harvested before the roots became injured by the second brood larvae; also that granular crude naphthalene applied six times at the rate of 400 pounds to the acre for each application gave nearly 100 per cent clean roots. Crop rotation should be practiced.

Celery worm, Papilio polyxenes. See Celery.

\section{Catalpa}

Catalpa leaf miner, Agromyza clara (?) This leaf miner starts a serpentine mine which later becomes a blotch mine, often involving the entire leaf. Little is known about life history or control.

Catalpa mealybug, Pseudococcus comstocki. This whitish pulverulent deposit in the crevices of the bark in the axils of the twigs and leaf stems and on the under side of the leaves may contain the adult females, nymphs and eggs, together with abundant wax secretion. There are two or three generations each year, and treatment is often necessary.

Good results were obtained in New Haven by spraying the trees the latter half of June with nicotine solution, 4 teaspoonfuls in a gallon of water with soap added.

White or West Indian peach scale, Aulacaspis pentagona. See Peach.

\section{Cauliflower}

Cabbage aphid, Brevicoryne brassicae. This aphid also infests cauliflower. See Cabbage.

Cabbage looper, Autographa brassicae. The cabbage looper also feeds upon cauliflower. See Cabbage.

Cabbage maggot, Hylemyia brassicae. This maggot also injures cauliflower. See Cabbage.

Cabbage worm, Pieris rapae. The cabbage worm also feeds upon cauliflower. See Cabbage.

Diamond-back moth, Plutella maculipennis. This insect also injures cauliflower. See Cabbage.

\section{Cedar}

Aphids. Red cedar trees are injured in May and June by Lachnus sabinae in Connecticut, and another species, Lachniella juniperivora may be found here. 
A spray of nicotine sulfate and soap is perhaps the best treatment.

Juniper scale, Diaspis carueli. This is a circular white scale that infests the leaves of red cedar and other species of juniper.

Spraying with a miscible oil, one part in 20 parts of water, in early spring has proved an effective remedy.

Juniper webworm, Dichomeris marginellus. This insect infests cedar and low juniper. See Juniper.

Red cedar bark beetle, Phloeosinus dentatus. This is a light brown or black beetle, one-sixteenth of an inch in length which excavates broad galleries under the bark, especially in sickly and dying trees. If trees are kept in vigorous condition, there will be little injury by this insect.

Severely injured trees should be removed and burned.

Spruce mite, Paratetranychus ununguis. This mite injures cedar. See Spruce.

\section{Celery}

Celery or greenhouse leaf tier, Phlyctaenia rubigalis. This insect injures many different kinds of plants and is often destructive in greenhouses. The caterpillar is about three-fourths of an inch in length when fully grown, translucent greenish white, with a narrow dark green median dorsal stripe. On each side of the median stripe is a broader pale stripe, then a broader dark stripe. When disturbed, the caterpillar wriggles violently and often drops to the ground. It usually feeds upon the under side of a leaf, but in some cases it webs together several leaves and remains inside the web. The adult is an inconspicuous rusty brown moth with a wing spread of seven-eighths of an inch. There are said to be four generations each year in the open, but seven or eight in greenhouses.

This insect is not a serious pest of celery in Connecticut and no particular control measures can be recommended.

Celery worm, Papilio polyxenes. There are two broods each year of this insect. The adult is the common, black swallow-tail butterfly, and the caterpillar, which is about two inches in length when mature, is green with a cross band of black on each segment. The chrysalis is suspended by a silk girdle to a stem or some convenient support. The butterfly has a wing spread of about three and one-half inches, but varies considerably in size. It is black with two nearly parallel rows of yellow spots or lunules across the outer margins of the wings. Between these rows on the rear wings are areas of light blue, with an orange spot on the rear margin.

This caterpillar is seldom very abundant and hand picking is the only means of control recommended. (Fig. 22.)

Tarnished plant bug, Lygus pratensis. This bug injures many different kinds of plants by sucking sap from the tender leaves and shoots. On celery the result shows as darkened sunken areas about one-fourth of an inch in diameter on the leaves and shoots near the top of the plants. It is a mottled brownish bug about one-fifth of an inch in length, that hibernates in rubbish and similar protected places. The eggs are inserted in the tender tissues of plant stems, leaves and buds, and the young bugs or nymphs are yellowish green and pass through five nymphal stages, the insect becoming mature at the fifth molt.

Good control was obtained at the Cornell Agricultural Experiment Station by dusting with sulfur, or spraying with sulfur and hydrated lime, $1 / 2$ pound of each to 1 gallon of water and applying 200 gallons to an acre. Five or six weekly applications should be given.

\section{Chard}

Bean aphid, Aphis rumicis. This aphid sometimes infests beet and chard. See Bean. 
Blister beetles. Several species. See Aster.

European corn borer, Pyrausta nubilalis. This insect is often a borer in the leaf stems of beet and chard. See Corn.

Flea beetles. Several species of flea beetles feed upon chard. See Beet.

Garden springtail, Sminthurus hortensis. This tiny insect of ten devours young seedlings of beet, chard and other garden vegetables. See Beet.

Spinach leaf miner, Pegomyia hyoscyami. This leaf miner often infests beet and chard. See Spinach.

\section{Cherry}

Black cherry aphid, Myzus cerasi. This is a brown aphid which occurs on the under side of the leaves, causing them to curl. It migrates to bluets and may be found on them late in summer, but passes the winter in the form of black glossy eggs on the twigs.

The remedy is to spray with nicotine sulfate solution and soap after the eggs hatch and before the leaves become curled.

Canker worms. See Apple.

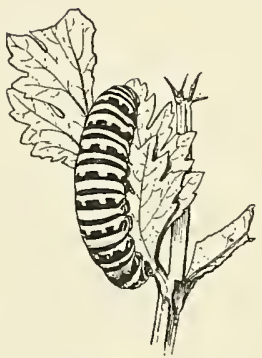

Figure 22.

Celery worm.

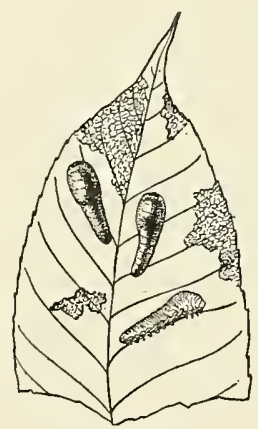

Figure 23.

Cherry and pear slug.

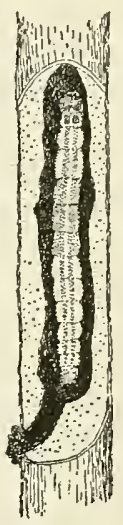

FIGURE 24. Stalk borer.

Cherry maggots or fruit flies, Rhagoletis cingulata and $R$. fausta. Two species of fruit flies occasionally cause wormy cherries in addition to the plum curculio. They are closely related to the apple maggot, which they resemble as the adults have banded wings. Both species each have one annual generation. Infested cherries do not fall but hang on the tree and sunken areas show on them. The flies of both species emerge in June.

In New York cherry orchards, these fruit flies are controlled by spraying the trees early in June with lead arsenate.

Cherry slug or pear slug, Eriocampoides limacina. The slug-like larvae feed upon the upper surface of the leaves especially on young trees, eating a way the green tissue and skeletonizing them. The adult is a small black, shiny, four-winged fly, called a sawfly, which appears in May and inserts eggs in blisters in the leaves. The larvae pass through five instars, but during the fifth go into the ground to pupate. Adults emerging in July and August lay eggs for a second generation, for there are two broods each season in the northern states.

The slugs may be killed by spraying the leaves with lead arsenate, also with fresh hellebore; with nicotine sulfate and soap; or with pyrethrumsoap. (Fig. 23.) 
Cherry tree tortrix, Archips cerasivorana. This insect often feeds upon both wild and cultivated cherry trees. The ends of the branches are enclosed in large pointed webs or nests with yellow larvae feeding upon the leaves. The adult moth has a wing spread of about an inch and the forewings are yellow with brown and blue markings. The females lay flattened egg-clusters on the bark of the branches and cover them with a glue-like material for protection. They remain until the following spring before they hatch.

The webs should be cut off and burned.

Eastern tent caterpillar, Malacosoma americana. See Apple.

Fall webworm, Hyphantria cunea. See Pear.

Plum curculio, Conotrachelus nenuphar. See Plum.

San José scale, Aspidiotus perniciosus. See Pear.

White peach scale, Aulacaspis pentagona. This scale occasionally infests flowering cherry. See Peach.

\section{Chestnut}

Aphids. The large gray aphid, Longistigma caryae, occurs on chestnut twigs. A smaller yellowish green aphid, Calaphis castaneae, is found on the leaves.

Spraying with nicotine sulfate and soap will control them.

Canker worms. Canker worms feed upon chestnut. See Apple.

Fall webworm, Hyphantria cunea. The fall webworm feeds upon chestnut. See Pear.

Gipsy moth, Porthetria dispar. Gipsy moth caterpillars feed upon chestnut. See Apple.

Leaf mites, Paratetranychus bicolor and Tetranychus bimaculatus. These mites infest chestnut and give the leaves a rusty brown color. See Oak and Phlox.

Two-lined chestnut borer, Agrilus bilineatus. The white flat-headed grubs of this beetle, make tortuous and interlacing galleries t1nder the bark of chestnut and oak. This grub is about half an inch in length, and the parent beetle is three-eighths of an inch long, black with two narrow converging longitudinal grayish stripes on the wing-covers. The beetles appear in May and June and deposit eggs. The grubs work in the inner bark and outer sapwood, pupating in cells in the wood. There is one annual generation each season, and mutilated, weakened, and dying trees are often infested and killed by this beetle. The adults feed somewhat upon the foliage, and some of them may be killed by spraying with lead arsenate late in May.

The removal and burning of all dead and dying wood will help in the control of this insect.

\section{Chinese Cabbage}

Aphids. The potato aphid, Macrosiphum solanifolii, has been recorded from Chinese cabbage. See Potato.

Purple-back cabbage worm, Evergestis straminalis This insect also infests cabbage, turnip and horse-radish, and is sometimes called the horse-radish webworm. The caterpillars feed upon the leaves, webbing them together, and sometimes they bore into the stem and roots. The mature caterpillar is about three-fourths of an inch in length, bristly, back purplish brown, with body tapering at both ends. A yellow stripe runs through the spiracles on each side and the underside is green. There are two and possibly three annual generations and the late brood of larvae 
causes the most injury. The moth has a wing spread of about an inch, the front wings are yellow, with veins and two narrow transverse lines of brown.

A spray of lead arsenate will prevent injury, but should not be used on plants which are soon to be used for food, especially if badly riddled. Perhaps pyrethrum-soap will prove effective.

\section{Chinese Lantern}

Tortoise beetles. Several species of tortoise beetles such as Chelymorpha cassidea, Deloyala clavata, Chiridia guttata and Metriona bicolor feed upon Chinese lantern. See Sweet potato.

\section{Chrysanthemum}

Aphids. Black fly, Macrosiphum sanborni, and green fly, Aphis rufomaculata, often infest chrysanthemum plants in the greenhouse. They may be controlled by cyanide fumigation, nicotine fumigation, or by spraying with nicotine sulfate or pyrethrum-soap.

Cyclamen mite, Tarsonemus pallidus. See Cyclamen.

European corn borer, Pyrausia nubilalis. See Corn.

Gall midge, Diarthronomyia hypogaea. A small slender two-winged fly lays eggs in the leaves and tender shoots in greenhouses and each larva forms a cone-shaped gall. Plants in the open are not usually injured. Probably there is more than one generation each year, but it is difficult to estimate the number on account of overlapping. The midge is more abundant in spring and fall than at other seasons.

Spraying with nicotine sulfate and soap or fumigating with tobacco or hydrocyanic acid gas every three or four days will keep this pest in check.

Marguerite fly, Phytomyza chrysanthemi. This insect is a leaf miner in the leaves of chrysanthemum. See Marguerite.

\section{Cineraria}

Aphid or green fly, Myzus persicae. Green aphids are often present on the under surface of the leaves and on the tender shoots of cineraria in greenhouses.

This pest may be checked by cyanide fumigation, nicotine fumigation, or by spraying with nicotine sulfate or pyrethrum-soap.

Greenhouse leaf tier, Phlyctaenia rubigalis. See Celery.

Greenhouse whitefly. Trialeurodes vaporariorum. See Tomato.

\section{Clematis}

Clematis borer, Alcathoe caudata. The larva of this moth is a borer in the fleshy roots of clematis, especially Clematis virginiana and $C$. jackmanii. The moth is a clear-wing of the family Sesiidae, with a wing spread of from one to one and one-fourth inches, the female being larger than the male. The former has head, thorax and abdomen blackish, with antennae fore-legs and rear tarsi, orange. Fore-wings are blackish or violaceous without transparent area. Rear wings transparent with dark margin. The latter has narrow transparent areas at base of fore-wings. The moths emerge between June 15 and August 15, and the winter is passed by the larvae in various stages of growth in the roots. There is one generation each year.

Tarnished plant bug, Lygus pratensis. This bug sucks the sap from the leaves, slightly deforming them. See Celery. 


\section{Clover}

Clover bud weevil, Phytonomus nigrirostris. The adults cut slits in the stem just above lateral buds. This is one of the most destructive pests of red clover in the middle-western states. The beetles are about an eighth of an inch long, green or blue-green in color with black head, and hibernate in woodlands. Small greenish larvae feed inside the stems or buds.

There is no satisfactory method of control.

Clover-head caterpillar, Laspeyresia interstinctana. Greenish white larvae feed in flower heads of red clover preventing development. The adult is a small moth about a quarter of an inch long, dark brown with oblique silver dashes on the front margins of the wings.

The only practical control is to harvest the crop early.

Clover leafhopper, Agallia sanguinolenta. This insect sucks the sap from the leaves, and the injury shows above as small whitish spots.

The control methods recommended for other insects injuring clover and alfalfa are the only remedies that can be practiced in the field.

Clover leaf weevil, Hypera punctata. The adults eat notches in the margins, sometimes devouring the entire leaves and eating into the stems. The grubs or larvae eat small areas from the under side of the leaves, which afterward become small round holes. As the larvae become larger they eat irregular notches in the leaves. The greatest injury occurs in May and there is probably only one generation each year in Connecticut. The adult weevil is about a quarter of an inch in length, light brown with three darker brown stripes running lengthwise on each wing-cover. The cocoon is oval with open mesh covering, yellow at first but later turning brown.

Early cutting of the crop in May or using the field for spring pasturage is the most practicable method of control.

Clover mite, Bryobia praetiosa. This is a large mite with fore-legs greatly elongated. It feeds upon clover, grasses and other herbaceous plants. This mite lays red eggs in autumn on trees, fences and buildings near clover fields in such enormous numbers as to fairly cover these objects with a red coating.

Cutting for hay as advised for other insects injuring clover is about the only practicable remedy. An oil spray may be used to kill the eggs on buildings and fences.

Green clover worm, Plathypena scabra. The caterpillars of this insect feed upon clover. See Bean.

Pea aphid, Illinoia pisi. Large green aphids occur on the leaves and stems from which they suck the sap, occasionally ruining the crop.

Prompt cutting for hay is one method of killing the aphids.

Red spider, Tetranychus bimaculatus. The red spider often infests clover. See Phlox.

\section{Coleus}

Greenhouse orthezia, Orthezia insignis. This insect is a common pest of coleus plants in greenhouses. See Lantana.

Greenhouse whitefly, Trialeurodesvaporariorum. This insect common$1 \mathrm{y}$ infests coleus plants in greenhouses. See Tomato.

Mealybugs, Pseudococcus sp. Coleus plants in greenhouses are very susceptible to infestation by mealybugs. See Lantana.

\section{Columbine}

Columbine borer, Papaipema purpurifascia. The larva of this moth is a borer in the stem of columbine, often going downward into the fleshy roots. The borer reaches a length of about one and one-half inches and is 
salmon-colored with a pale stripe along the back. The moth has a wing spread of one and one-fourth inches, and the fore-wings are light reddish brown in color with darker cross bands and purplish distal margins.

Remove and destroy infested plants. Possibly the borers in the roots may be destroyed by injecting a fluid ounce of carbon disulfide into the soil near the plant.

Columbine leaf miners, Phytomyza minuscula and $P$. aquilegiana. The larva of the former makes a serpentine mine in the leaf, beginning in June. There are often several miners in a leaf and the mines coalesce, appearing later in the season as a blotch mine. The adult is a small two-winged fly that lays eggs in the under sides of the leaves, and there are several generations each year. When the miners reach maturity, they emerge through

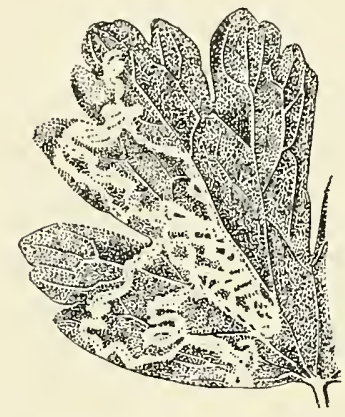

Figure 25. Serpentine leaf mine of columbine.

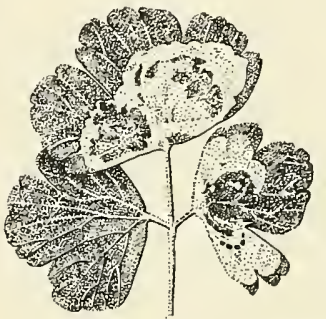

Figure 26. Blotch leaf mine of columbine.

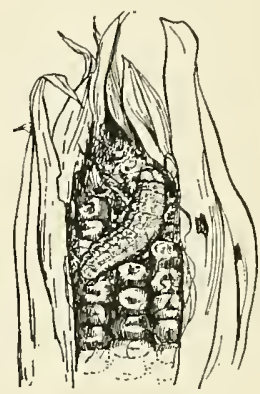

Figure 27.

Corn ear worm.

crescent-shaped cuts, pupate, and attach their oval brown puparia endwise to the under side of the leaf. In two weeks the adults emerge. In late fall the larvae pupate in the ground where the insect spends the winter. The latter, $P$. aquilegiana, makes a blotch mine from the first, beginning near the base of the leaflets. Little is known about the life history of this species.

If the first infested leaves are picked and burned and the ground around the plants cultivated in late fall or early spring, the infestation will be reduced. Possibly a spray of nicotine or pyrethrum-soap will kill some of the larvae, but this has not been demonstrated. (Figs. 25 and 26.)

Stalk borer, Papaipema nitela. The stalk borer occasionally tunnels in the stalks of columbine. See Dahlia.

\section{Coreopsis}

Leaf beetle, Chrysomela elegans. This beetle occasionally feeds upon the leaves and flower stems of Coreopsis lanceolata, causing injury. It is one-fourth of an inch or less in length, dark bronze green, with two narrow cream-colored stripes lengthwise of each wing-cover.

Spraying with lead arsenate is effective.

\section{Corn}

Aphids. The corn leaf aphid, Aphis maidis, often infests the leaves, though it seldom causes much injury to corn in Connecticut. The corn root aphid, Anuraphis maidi-radicis, infests the roots of corn and has been collected on corn in Connecticut. 
Spraying with nicotine sulfate is a remedy for the former, but the latter is more difficult to control.

Armyworm, Cirphis unipuncta. See Grass.

Corn ear worm, Heliothis obsoleta. The caterpillars of this insect feed upon the silk and the kernels at the tip of the ear sometimes tunneling underneath the husk. They reach a length of nearly two inches when fully grown and vary in color from a light green or tan to a dark purplish brown, with more or less distinct longitudinal stripes. The moth has a wing spread of one and one-half inches, and is light tan in color with darker wing-margins. There are probably two or three annual generations in the northern states and four or five in the cotton states, where the insect is known as "cotton boll worm" or "tomato boll worm." Caterpillars arrive in Connecticut each season on sweet corn from the southern states. Whenever we have tried to rear the adults from late maturing caterpillars, they have died during the winter unless in a protected location. In the southern region it winters as a pupa in the ground.

The moth lays eggs singly on the corn silk, and dusting the silk soon after it appears, using lead arsenate and powdered sulfur equal parts, will give partial control, but. its value is questioned by some experimenters.

(Fig. 27.)

Corn root webworm, Crambus caliginosellus. The larvae of this insect and that of a closely related species, Crambus praefectellus, occasionally injure corn, especially on sod land, by eating into the side of the stalk just above the surface of the ground. The larva is about half an inch long and dirty white or gray with dark tubercles. The moths of both species have a wing spread of about three-fourths of an inch; those of caliginosellus are medium gray or brown without prominent markings; praefeclell.us has light brown fore-wings with a white stripe in the middle, and white rear wings.

There is no good remedy, except to avoid sod land for corn.

Cutworms, several species. See Tomato.

European corn borer, Pyrausta nubilalis. This pest was first discovered in this country in eastern Massachusetts in 191\%, and has now spread nearly over Connecticut. Larvae tunnel in the stalks and ears in all directions, weakening the stalks so that they break over. Breaking over of the tassels is one of the signs first noticed. The larva is dirty white or gray with black tubercles and is not more than an inch in length when full grown. Adults have a wing spread of an inch or slightly more, female pale buff with irregular narrow brown cross-lines, male brown with lighter cross lines. There are two generations usually, but the corn borer infestation of New York and westward has one annual generation and has spread into the northwest corner of Connecticut. Eggs are laid on the leaves, and the larvae tunnel in the stalks and pupate in the burrows. Second generation larvae and those of the single brooded corn borer live over winter in the stalks and pupate in the spring.

Control measures consist of close cutting of the stalks and making ensilage of them; or feeding them to livestock; burning or plowing the stalks and larger weeds under cleanly. Clean-up work is now compulsory in Connecticut. (Fig. 28.)

Grass thrips, Anaphothrips striatus. The leaves of corn are sometimes injured by thrips, which make narrow chain-like markings where they have eaten on the surface. Several specimens of this type of injury have been received in Connecticut.

Usually no control measures are necessary, but in the house garden a spray of nicotine sulfate and soap would probably prove effective.

Japanese beetle, Popillia japonica. This insect has the habit of clustering at the tips of ears of sweet corn. See Rose.

Leaf miners. The corn leaf miner or spike-horned leaf miner, Cerodonta femoralis (Odontocera dorsalis) makes a linear mine usually near the margin 
or mid-vein, and the corn blotch leaf miner, Agromyza parvicornis, makes a broad linear or blotch mine near the base of the leaf.

Control measures are seldom needed and have not been worked out.

Seed corn maggot, Hylemyia cilicrura. The maggots of this small fly infest the seeds of vegetables and injure or destroy them in the ground so that they do not produce good plants. The damage is much greater in cold wet weather, and by a shallow covering of soil the injury is less than in the case of deep planting.

Stalk borer, Papaipema nitela. See Dahlia.

White grubs, Phyllophaga, several species. The larvae of several species feed upon the roots of corn and other plants, of ten causing much injury. Three years are required to complete the life cycle. The adults lay eggs in the soil in June, and the grubs feed upon the roots and do most of the damage late in summer of the third season when they are large and voracious. The following spring they pupate in the ground and the adults soon emerge. The greatest injury occurs on sod land, and such land should be avoided for corn and other hoed crops.

Fall plowing, thorough disking, and cultivating are good cultural practices for the control of these insects.

Wireworms, several species. See Tobacco.

\section{Cornflower}

Stalk borer, Papaipema nitela. See Dahlia.

\section{Cosmos}

Stalk borer, Papaipema nitela. See Dahlia.

\section{Cotoneaster}

San José scale, Aspidiotus perniciosus. See Pear.

\section{Cow Pea}

Aphid, Aphis rumicis. See Bean.

Mexican bean beetle, Epilachna corrupta. See Bean.

\section{Cranberry}

Black-headed cranberry worm or fireworm, Rhopobota naevana. This is one of the most destructive insects of cranberry, and there are two broods each year. The insect passes the winter in the egg stage on the leaves and the eggs hatch at the time growth begins in the spring. The young larva is pale green with glossy black head. It webs together the expanding leaves at the tip and feeds inside the webbed leaves. It becomes mature in about three weeks, and is then dark green with black head and is about half an inch in length. It then pupates on the ground or within the webbed leaves and the moth emerges in about a week. It is ash-gray with irregular brownish bands across the fore-wings, and has a wing spread of about three-eighths of an inch. The first brood of moths emerge in June and the second brood in late July and August.

Control measures consist in flooding the bog when the insect is in the pupa stage and spraying with lead arsenate at the rate of 6 or 7 pounds in 50 gallons of water to kill the larvae. The poison should be applied just after the eggs hatch. 
Cranberry fruit worm, Mineola vaccinii. The pale green larvae of this insect infest the berries and are present in nearly every bog, often causing considerable injury. There is only one annual generation and the moths emerge in July and lay eggs on the berries. These eggs hatch in five days, and the young larvae eat into the berries usually near the stem, closing the hole with a silk web. The larva eats out the pulp and then goes into a second and sometimes into a third or fourth berry, becoming mature in late August or September. It is then about seven-eighths of an inch in length. The parent moths are ash-gray mottled with black, and have a wing spread of about three-fourths of an inch.

Flooding the bogs for 10 days or two weeks after harvesting, and early in May, together with the destruction of the infested berries removed by screening, are the best methods of control.

Gipsy moth, Porthetria dispar. The caterpillars feed upon cranberry. See Apple.

Yellow-headed cranberry worm, Peronea minuta. This insect is often injurious on the drier bogs and there are two and possibly three broods each year. The insect hibernates in the adult stage, a slate-gray moth with wing spread of about three-fourths of an inch. The moths lay eggs on the leaves in May, and the eggs hatch in 10 days. The caterpillars web the leaves together and feed within these nests. They pupate in the nests in June, the second brood of caterpillars feed in July and the third in New Jersey in August and September.

Control measures consist in keeping the bog flooded until about May 20 , and in spraying the drier bogs with lead arsenate just as the eggs hatch, using 10 pounds of the poison in 100 gallons of water.

\section{Cucumber}

Cucumber or potato flea beetle, Epitrix cucumeris. See Potato.

Melon aphid, Aphis gossypii. See Melon.

Melon worm, Diaphania hyalinata. See Melon.

Pickle worm, Diaphania nitidalis. This insect injured cucumbers and squashes in Connecticut in 1931. The adult is a moth with wing expanse of slightly more than an inch. Both front and rear wings have the central portion hyaline and the margins are gray and opaque. At the end of the abdomen of both sexes there is a brush of long scales; this is larger in the male. The eggs are laid at night, singly or in small groups on the flower buds or tender terminal leaves. They hatch in three or four days and the young larvae burrow into the bud or blossom. Some complete their development in the vines, but others migrate to the fruit into which they tunnel. The fully grown larva is about three-fifths of an inch in length, white, yellowish or greenish with yellowish brown head and thoracic shield. The number of generations of this insect in Connecticut is not known, but there are four in North Carolina.

There are no satisfactory control measures other than destroying all vines and waste fruits, early fall plowing, and rotation of crops. By planting the crop early much of the damage will be avoided.

Spotted cucumber beetle, Diabrotica duodecimpunctata. This is a minor pest which occasionally causes injury. It is somewhat larger than the striped cucumber beetle, and the wing-covers are greenish yellow marked with 12 black spots varying in size and arranged in three transverse rows. The life history and control is similar to that of the striped beetle.

Striped cucumber beetle, Diabrotica vittata. This is the most destructive insect pest of cucumbers. The beetles hibernate under trash or in the ground, and appear upon the plants as soon as the seed germinates. The greatest injury occurs to the young plants, and the beetles feed usually on the under side of the leaves, and often on both sides. The beetles are one- 
fourth of an inch or less in length, with thorax and wing-covers yellow, with three black longitudinal stripes on the wing-covers, and with black head. The eggs are laid the last of June on the surface of the ground or in crevices in the soil, and oviposition continues for about a month. The eggs hatch in about a week and the young larvae work their way downward along the main stem where they burrow into it, causing much injury, especially by inoculating the plants with bacterial wilt. A full-grown larva is one-third of an inch long, slender and white with brown head, thoracic and anal plates. There is only one annual generation.

In the small garden perhaps the simplest measure of control is to cover the hills with screen protectors. In the field the plants should be kept dusted with calcium arsenate, 1 part, and gypsum 15 parts, or kept covered with a spray of calcium arsenate and Bordeaux mixture. (See Fig. 29.)

\section{Currant}

Currant aphid, Myzus ribis. This aphid is usually found on the under side of the tender terminal leaves which become more or less curled or blistered by it. Glossy black eggs on the twigs of the new growth carry the insect through the winter. These eggs hatch soon after the first leaves unfold. There are many generations during the summer that are born alive, most of them females without wings. When the aphids become overcrowded, winged females develop and migrate to other currant plants. The distorted and curled leaves often turn red and drop. After midsummer the aphids become less abundant on account of natural enemies, but enough females survive to lay eggs on the $t$ wigs in October.

For the best control the plants should be sprayed thoroughly soon after the eggs hatch, with nicotine solution and soap.

Currant borer, Synanthedon tipuliformis. Certain stems that appear to be unthrifty and finally die usually have the center or pith tunneled by the larva of this insect. The eggs are deposited singly on the bark. The full-grown larva is about half an inch in length and is white with brown head and legs. The adult is one of the clear-winged moths with wing spread of about three-fourths of an inch. The wings are transparent with opaque purplish margins. There is one brood each year, and the moths emerge in June.

Sickly canes should be cut off and burned before June 1 .

Currant fruit fly, Epochra canadensis. This insect of ten causes serious injury to currant and gooseberry. The larva or maggot infests the berries, which may hang on the bushes or drop to the ground. There is only one brood each year, and the winter is passed in the pupa stage in the ground. The adult fly is about the size of the house fly, but is pale yellowish in color with banded wings.

There is no satisfactory method of control.

Currant stem girdler, Janus integer. This insect is a sawfly that lays an egg in May in the new shoot and girdles it or cuts it partly off an inch or less above the egg. These tips break off altogether or hang from the canes. On the hatching of the egg, the young larva burrows downward in the pith to a distance of not more than six inches. About September 1, the larva reaches maturity and cleans out the lower end of the burrow, and eats a passageway to the outer bark. It passes the winter as a larva in the burrow and pupates in the spring. There is one brood each year.

The only known remedy is to clip off and burn the tips of the canes.

Four-lined plant bug, Poecilocapsus lineatus. This bug lays eggs in the soft stems, and they hatch about the middle of May and the young bugs suck the sap from the tender leaves. They molt five times and when mature about the middle of June they have wings and are nearly one-third of an inch in length. In color they are yellow and are marked lengthwise 
on the back with four black stripes alternating with three green stripes. The injury to the leaves consists of sunken areas around the punctures. These areas later appear as circular transparent spots and finally as circular holes. This insect injures the new leaves of many different kinds of annual and perennial plants and shrubs. There is only one generation each year.

The nymphs can be destroyed by spraying with nicotine sulfate and soap or with pyrethrum-soap. (Fig. 88).

Gooseberry span worm, Cymatophora ribearia. See Gooseberry.

Imported currant worm, Pteronidea ribesii. The adult sawflies emerge when the currant leaves first unfold, and lay white elongate eggs end to end in rows along the veins on the under side of the leaves of currant and gooseberry. The eggs hatch in a week or 10 days, and the larvae feed upon the leaves, becoming full-grown in from two to three weeks, when they are about three-fourths of an inch in length. During most of the

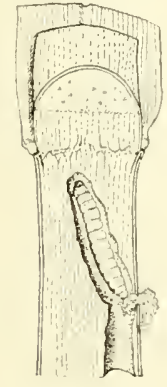

Figure 2S.

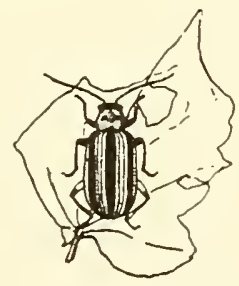

FIGLRE 29.

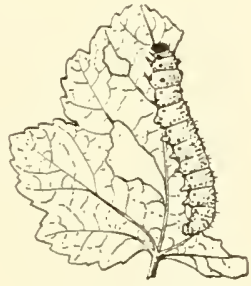

FigLRE 30.

European corn borer. Striped cucumber beetle. Currant worm.

feeding period the larvae are grayish green covered with black spots but at the last molt, they lose the black spots and are uniform green. They pupate beneath leaves or trash on the ground and a second brood of adults appear in late June or early July and lay eggs for a second brood of larvae. It is the first brood that causes most of the injury and the second brood is of little account.

The best remedy is to spray with lead arsenate when the first brood larvae begin to feed. If treatment seems necessary when the fruit is near maturity, fresh hellebore may be used at the rate of 4 ounces in 2 gallons of water, or as a dust, 1 pound mixed with 5 pounds of flour or air-slaked lime. (Fig. 30.)

San José scale, Aspidiotus perniciosus. See Peach.

Scurfy scale, Chionaspis furfura. See Pear.

\section{Currant (Yellow Flowering)}

Aphids. The Missouri currant sometimes becomes infested by A phis sanborni, but a satisfactory control is obtained by thoroughly spraying with nicotine sulfate and soap, or with pyrethrum-soap.

\section{Cyclamen}

Black vine weevil, Brachyrhinus sulcatus. The grubs devour the roots of cyclamen. See Yew. 
Cyclamen mite, Tarsonemus pallidus. This translucent microscopic mite often infests the new leaf and blossom buds causing them to become swollen and distorted. Infested plants give no satisfactory blossoms.

The best control consists of fumigating with naphthalene or spraying the plants twice a week or dipping them into the mixture, using nicotine stilfate and soap.

\section{Dahlia}

European corn borer, Pyrausta nubilalis. See Corn.

Giant hornet, Vespa crabro. This is the largest hornet occurring in Connecticut, and many individuals are more than an inch in length. The general color is dark brown with a broad band of orange yellow on the rear margin of each abdominal segment. This hornet nests in hollow trees and gathers wood fibers to be used in constructing the nest. Sometimes it removes the bark from twigs of lilac, arborvitae, and other shrubs and trees, thus girdling them. In 1920, several dahlia plants were injured and two killed in New Haven by gnawing off the bark.

No treatment can be recommended, though possibly a spray of limesulfur might act as a repellent.

Stalk borer, Papaipema nitela. This borer infests an occasional stalk of many kinds of herbaceous plants and it frequently causes rather severe injury to dahlia. As a rule its presence escapes notice until the plant begins to wilt. Then it is too late for the plant to recover. The larva tunnels up and down inside the stem, and the top portion usually wilts and later dies. There is one annual generation, and the moths emerge in September and October and lay eggs on the stalks of their food plants, in which stage the insect passes the winter. The eggs hatch in May or early June, and the young larva begins to feed upon the leaves of the nearest food plant, and later tunnels in the stem. The mature larva is nearly one and one-half inches in length, grayish brown with one white dorsal stripe, and two white lateral stripes on each side. On the front half of the body the lateral stripes are interrupted, and the lower brown stripe extends forward onto the side of the head.

Burning all the old stalks and the weeds around the field helps control this insect. By examining the plants frequently the presence of borers may be detected by the sawdust thrown out. By cutting lengthwise carefully the borer may be killed without serious injury to the plant. Certain growers claim success by injecting a few drops of various materials into the burrow and closing the opening. Some use gasoline, others carbon disulfide, lead arsenate and nicotine sulfate. (Fig. 24.)

Tarnished plant bug, Lygus pratensis. This bug punctures the buds and new shoots, causing deformity. See Apple.

\section{Dandelion}

Aphids. The dandelion aphid, Macrosiphum taraxaci, the melon aphid, Aphis gossypii, and the spinach aphid Myzus persicae and probably other species infest the dandelion crop. Spraying with nicotine sulfate and soap will kill them.

Chrysanthemum leaf miner, Phytomyza chrysanthemi. This leaf miner sometimes infests dandelion. See Marguerite.

\section{Dewberry}

Blackberry knot gall, Diastrophus nebulosus. This gall occurs on the stems of dewberry and blackberry. It contains many larval cells and varies from one to three inches in length, and from one to one and one-half 
inches in diameter. It is often deeply furrowed lengthwise and when first found is dark green, but later it turns to red and brown.

No method of control is known other than removing and burning the galls.

\section{Dogwood}

Cottony maple-leaf scale, Pulvinaria acericola. This insect occasionally infests the leaves of flowering dogwood. See Maple.

Dogwood clear-wing, Sesia scitula. The larva of this moth is a borer under the edges of bark of the flowering dogwood, particularly around wounds and mutilations. The larva is white with pale brown head. The adult moth has a wing spread of about an inch, wings transparent with blue-black margins, thorax and abdomen blue-black, with narrow yellow rings on the second and fourth abdominal segments.

Control measures are seldom necessary and none can be recommended.

Dogwood club gall, Lasioptera clavula. This is a tubular swelling containing a larva, occurring on the small twigs, often killing them back for several inches. The adult is a small fly or gall midge emerging in May or June.

There is no remedy.

Dogwood twig girdler, Oberea tripunctata. The larva of one of the small long-horned beetles is a borer in the terminal twigs of several species of dogwood. The eggs are laid in June and July, hatch in about 10 days and the young larva tunnels downward in the twig making several openings through the bark so that the frass may be thrown out. The twig is girdled above and below where the egg was deposited. The winter is passed in the burrow by the full-grown larva and pupation takes place in the spring. There is apparently one generation each year.

Cutting and burning the infested twigs will help control this insect.

Mulberry whitefly, Tetraleurodes mori, often infests the leaves of dogwood. See Mulberry.

San Jose scale, Aspidiotus perniciosus. This scale frequently infests the stems of dogwood, especially the smaller green and red twig varieties used in ornamental plantings.

Spray with nicotine sulfate and soap or when dormant with miscible oil or lime sulfur. See Pear.

\section{Dutchman's Pipe Vine}

Pipe vine caterpillar, Laertias philenor. Wherever the Dutchman's pipe vine is grown, the leaves may be devoured by brown non-hairy caterpillars, with two rows of coral red dots along the back. When mature, the caterpillar may reach a length of two and one-half inches, and fleshy filaments are borne on each end of the body. The adult is the blue swallowtail butterfly which has a wing spread varying from two and one-half to three and one-half inches. The fore-wings are brownish black, and the rear wings are dark greenish blue, with white marginal spots or lunules.

Spraying the leaves with lead arsenate is the remedy.

\section{Egg-Plant}

Colorado potato beetle, Leptinotarsa decemlineata. This beetle in both the larval and adult stages feeds upon egg-plant. See Potato.

Cutworms. See Tomato.

Potato aphid, Macrosiphum solanifolii. This aphid sometimes feeds on egg-plant. See Potato. 
Potato flea beetle, Epitrix cucumeris. The potato flea beetle also feeds upon the leaves of egg-plant. See Potato.

Tobacco worm, Phlegethontius quinquemaculata. The tobacco worm and the tomato worm, $P$. sexta, both occur in Connecticut and occasionally feed upon egg-plant. See Tobacco and Tomato.

\section{Eim}

Canker worms. Both fall and spring canker worms often partially defoliate elm trees. See Apple.

Elm leaf beetle, Galerucella luteola. This insect is capable of causing serious injury to elm trees by devouring the leaves. The beetles hibernate in attics, belfries, and other protected places, and they emerge and fly into the trees as soon as the new leaves unfold. They feed somewhat, eating round holes through the leaves. They mate, and late in May the females lay yellow eggs in clusters on the under side of the leaves. These eggs hatch early in June and the grubs or larvae eat a way the under surface, leaving the network and upper epidermis, becoming mature about the middle of July, when they descend to the ground and transform to bright yellow pupae on the surface of the ground around the base of the tree. Ten days later the beetles emerge and fly into the trees. Some may lay eggs, but there is only a partial second brood in Connecticut, and the beetles go early into their winter quarters. This beetle is about one-fourth of an inch in length, and buff with an olive-green stripe along the outer margin of each wing-cover.

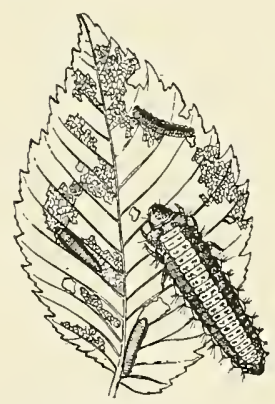

FIGURE 31.

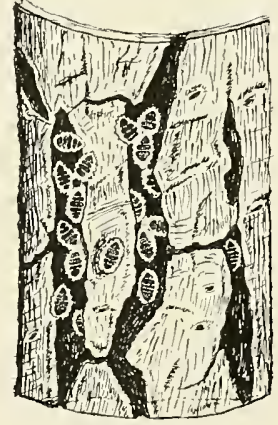

Figure 32.

European elm scale. Leopard moth caterpillar.

It is important that the over-wintering beetles be gathered and burned. The best protective measure is to spray thoroughly the under surface of the leaves early in June with lead arsenate, using about five pounds in 100 gallons of water. Pupae at base of trees may be killed by spraying with nicotine sulfate or pyrethrum-soap. Bulletin 155 of this Station gives a full account of this insect. (See Fig. 31.)

Elm scurfy scale, Chionaspis americana. This is a whitish pear-shaped scale that sometimes occurs on the twigs and branches of elm trees. It passes the winter in the egg stage and there are two generations each year. The control measures recommended are dormant spring applications of lime-sulfur or of miscible oil.

European elm scale, Gossyparia spuria. This is a soft-bodied unarmored scale, chocolate brown with marginal fringe of white wax, that occurs 
in the crevices of the bark of trunk and lower branches. It is oval in shape and about one-tenth of an inch in length. The young appear in June and there is only one generation each year.

Spraying with nicotine sulfate and soap, or a dormant spray with miscible oil will control this scale. (See Fig. 32.)

Gipsy moth, Porthetria dispar. The caterpillars feed upon elm leaves. See Apple.

Leopard moth, Zeuzera pyrina. The leopard moth has caused serious injury to elm in Connecticut and it also injures maple, birch, apple and many other kinds of trees. The moths are dirty white, marked with metallic blue dots and have a wing spread of one and three-fourths inches in the male to two and one-half inches in the female. Emerging in July, the female lays oval orange-yellow eggs singly or in groups in the crevices of the bark or near the buds. The young larvae tunnel in the small twigs and reach a length of about an inch at the end of the season. They then enter larger branches, excavating large galleries, and often girdling them. The frass is expelled through round holes which they soon close with silk webs. During the second October of their larval stage they tunnel deeper into the wood and remain through the winter in cavities two inches or more beneath the bark. The larva reaches a length of two and one-fourth inches, is dirty white, yellowish or pinkish, spotted with brown or black tubercles. The head, cervical and anal shields are dark brown. The larva pupates in the burrow and from four to six weeks later the moth emerges.

Removing and burning infested branches, injecting carbon disulfide or other materials into the burrow and closing the opening, are the usual methods of control. Bulletin 169 of this Station deals with this insect. (See Fig. 33.)

Spiny elm caterpillar, Euvanessa antiopa. This is the larva of the mourning cloak butterfly that lays eggs in cylindrical clusters on the small twigs of elm, poplar and willow. The larvae hatching from the eggs feed together in a cluster and soon strip the branch. The full-grown caterpillar is about two inches in length, black sprinkled with small white dots giving it a hoary or grayish appearance. Along the back is a row of red spots somewhat diamond-shaped. Each segment bears several black branched spines arranged approximately in transverse rows. The butterfly has a wing spread of two and one-half to three inches and is purplish brown with yellow wing margins. The cocoon is suspended by the tail, is about an inch in length and has a row of spine-like projections along the ventral surface. There are two annual generations.

Clipping off the twig as soon as caterpillars are noticed, and burning or crushing the caterpillars, and spraying with lead arsenate are the measures of control. (See Fig. 34.)

Twig injury by squirrels. The small twigs of elm trees are often cut off in large numbers the latter half of May by squirrels. Nost of these are the flowering twigs and the brown seeds are then nearly ripe. Presumably the squirrels feed upon these seeds, but the twigs are too slender to bear the weight of the squirrel; so he cuts them off and they fall to the ground where he goes to eat the seeds. There is no remedy other than to provide nuts or other food for squirrels at this time.

White-marked tussock moth, Hemerocampa leucostigma. The larvae feed upon elm foliage. See Horsechestnut.

Woolly elm aphids. Several species of woolly aphids of the genus Eriosoma occur on the elm. Eriosoma americanum causes a leaf roll on American elm and $E$. ulmi a similar leaf roll on English elm. The apple woolly aphid, E. lanigera (See Apple) has the elm for a native alternate host, from which it migrates to the apple. On elm the females hatching from the over-wintering eggs cause a leaf deformation known as rosette or leaf cluster. E. lanuginosa forms a bag-like gall one and one-half inches in 
length on the leaf. E. rileyi congregates in flocculent white masses on the bark causing a knotty growth.

Except where they are inside galls or rolled leaves, these aphids may be killed by a spray of nicotine sulfate and soap.

\section{Endive}

Aphids. The bean aphid, Aphis rumicis, the pea aphid, Illinoia pisi, and the lettuce aphid, Macrosiphum sonchi, are all known to feed upon endive and all occur in Connecticut.

They may be killed by a spray of nicotine sulfate and soap.

\section{Euonymus}

Aphids. The bean aphid, Aphis rumicis, occurs on Euonymus and probably other species also. See Bean.

Cottony maple scale, Pulvinaria vitis. This scale infests Euonymus. See Maple.

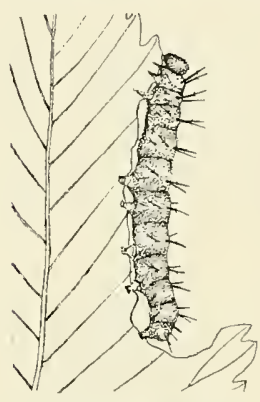

FiguRe 34.

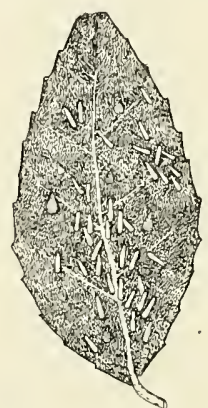

Figure 3 5.

Spiny elm caterpiliar.

Euonymus scale.

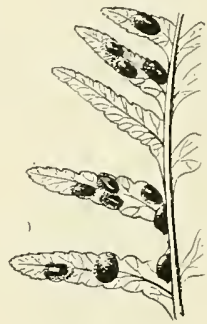

FIGURE 36.

Euonymus scale, Chionaspis enonymi. This is perhaps the most serious pest of Euonymus, and it often kills entire branches. It also infests bittersweet and Pachysandra. The female shells are gray and pear-shaped, and the male shells are smaller, narrower and whiter. There are probably two broods each season, and the winter is passed in a nearly mature condition; eggs are formed during May and hatch later in the month. All badly infested and injured branches should be cut and burned.

Spraying with miscible oil when the plant is dormant, or spraying in early June with nicotine sulfate and soap to kill the young, are the chief control measures. (See Fig. 35.)

\section{Exochorda}

Gall mite, Eriophyes sp. A species of mite is responsible for small galls on the leaves, usually on the upper surface.

Probably this mite can be controlled by a dormant spray of lime-sulfur in early spring just before the leaves appear.

\section{Fern}

Fern aphid, Idiopterus nephrelepidis. This black aphid often infests the under surface of the fronds of the Boston fern, though seldom causing severe injury. The remedy is to spray with nicotine sulfate and soap, or if the plants are in small pots to dip them in the mixture. 
Fern scale, Hemichionaspis aspidistrae. This armored scale infests the Boston fern in greenhouses and dwellings. The female scale is about onetwelfth of an inch in length, pear-shaped, light brown in color, and the male is smaller, pure white, narrow with parallel sides and with a distinct longitudinal ridge. Both occur on the under side of the fronds.

This insect may be kept in check by frequent spraying with nicotine sulfate and by fumigating the greenhouses with hydrocyanic acid gas.

Hemispherical scale, Saissetia hemisphaerica. This very convex brown hemispherical unarmored scale often infests the stems and fronds of Boston and other ferns.

It may be readily controlled by a spray of nicotine sulfate. (Fig. 36.)

Soft scale, Coccus hesperidum. This unarmored scale is very thin and flat, oval, and semi-transparent. It infests many different greenhouse plants including ferns.

The control is the same as for other scales, a spray of nicotine sulfate and soap.

Yellow woolly bear, Diacrisia virginica. Ferns out-of-doors are often eaten by these yellow hairy caterpillars. See Verbena.

\section{Fir}

Spruce budworm, IIarmologa fumiferana. This insect also infests balsam fir which is sometimes more severely injured than spruce. See Spruce.

Spruce mite, Paratetranychus ununguis. This mite infests nearly all kinds of conifers including fir. See Spruce.

\section{Fuchsia}

Greenhouse whitefly, Trialeurodes vaporariorum. This whitefly often infests Fuchsia in the greenhouse. See Tomato.

Mealybug, Pseudococcus citri. The common mealybug and probably other species infest Fuchsia. See Lantana.

\section{Gardenia}

Fuller's rose weevil, Asynonychus godmani. This weevil sometimes injures Gardenia. See Rose.

Greenhouse orthezia, Orthezia insignis. This insect also infests Gardenia. See Lantana.

Soft scale, Coccus hesperidum. This scale is often found on Gardenia. See Fern.

\section{Geranium}

Aphids. Certain species of aphids like the spinach aphid, Myzus persicae, probably the bean aphid, Aphis rumicis and perhaps other species sometimes infest geranium plants. A spray of nicotine sulfate and soap will destroy the aphids.

Corn ear worm, Heliothis obsoleta. This insect injured geranium plants in the late fall of 1931 in Bridgeport, Portland, Hartford and Groton.

Probably a spray of lead arsenate would be effective in such a case. See Corn.

Cyclamen mite, Tarsonemus pallidus. This mite occasionally curls the leaves of geranium. See Cyclamen.

Garden slugs. See Lettuce. 
Greenhouse leaf tier, Phlyctaenia rubigalis. This insect often injures geranium and other plants in greenhouses. See Celery.

Greenhouse whitefly, Trialeurodes vaporariorum. This insect often infests geranium and other plants under glass. See Tomato.

Mealybug, Pseudococcus citri. Mealybugs often injure geranium and other plants in greenhouses. See Araucaria.

White ant, Reticulitermes flavipes. This insect lives in colonies and the wingless immature insects are white and burrow in wood. The adults are brown and have wings. The colony usually nests in old stumps, fence posts or the structural timbers of buildings. In several cases both in the field and greenhouse, these ants have tunneled out the stems of geranium plants.

Probably the best remedy is to eradicate the colony by fumigating with carbon disulfide.

\section{Gladiolus}

Cutworms. Various species of cutworms occasionally injure gladiolus. See Tomato.

Gladiolus thrips, Taeniothrips gladioli. This and other species of thrips caused great injury to gladiolus in 1931. The flower buds were injured so that no good blossoms resulted. The minute insects hide in the sheaths of the flower stem where it is difficult to reach them with a spray.

Burning the old stalks and trash on the field may help in the control of this insect. Corms from an infested field should be treated after drying and cleaning as the thrips cause injury in storage. Place in tight paper bags and scatter an ounce of flake naphthalene among each 100 corms. Fold the tops of the bags to make them tight and keep them closed for two or three weeks. Frequent spraying of the plants when small with nicotine sulfate or pyrethrum, 1-200, with soap added as a spreader is recommended.

Tulip aphid, Anuraphis tulipae. This aphid sometimes hibernates on the stored corms, and causes great injury, especially on the new growth. See Tulip.

Zebra caterpillar, Mamestra picta. This caterpillar feeds upon many different plants in the garden, including gladiolus. See Cabbage.

\section{Golden Glow}

Sawfly, Macrophya simillima. The larva of this insect sometimes defoliates the plants. It is about three-fourths of an inch in length when full-grown, light gray with darker gray median stripe and a row of large black spots on each side about half way between the median stripe and the spiracles. It coils when resting on the leaves. The adults emerge early in June and there is one brood annually.

A spray of lead arsenate is the remedy.

Stalk borer, Papaipema nitela. This borer is often found in an occasional stalk of golden glow. See Dahlia.

Stem aphid, Macrosiphum rudbeckiae. This red aphid often infests the tender shoots and may literally cover the topmost portion, sucking the sap.

A good remedy is to spray with nicotine sulfate and soap.

\section{Gooseberry}

Currant fruit fly, Epochra canadensis. This insect also infests gooseberry. See Currant. 
Gooseberry fruit worm, Zophodia grossulariae. Gooseberry fruit is sometimes infested by greenish larvae, three-fourths of an inch long, with brown head. Infested berries usually color prematurely and may either dry up on the bushes or fall to the ground and decay. The moth has a wing expanse of about an inch, and is grayish in color with darker lines across the fore-wings and a row of small black spots near the outer margin. The life history of this insect has not been thoroughly worked out, but apparently there is only one annual generation. It passes the winter in the pupa stage under dead leaves and trash on the ground. There is no treatment to be recommended other than destroying the infested berries.

Gooseberry span-worm, Cymatophora ribearia. This insect occasionally feeds upon gooseberry and currant, and the larva is about an inch in length when full-grown. It has the habit of a measuring worm and loops when it crawls. It is whitish with yellow stripes and black spots. It pupates in the ground and the moth emerges late in June. It has a wing spread of about one and one-fourth inches, is light buff in color with a row of parallel gray dashes across each wing. The eggs are laid on the bark in July and hatch the following spring.

Treatment is seldom needed, but a spray of lead arsenate is effective when the larvae are small.

Imported currant worm, Pteronidea ribesii. The larvae feed upon gooseberry. See Currant.

\section{Gourds}

Melon aphid, Aphis gossypii. This aphid also infests gourds. See Melon.

Squash bug, Anasa tristis. This bug sometimes injures gourds. See Squash.

Squash vine borer, Melittia satyriniformis. The squash vine borer is also a pest of gourds. See Squash.

Striped cucumber beetle, Diabrotica vittata. This insect may injure all plants of the family Cucurbitaceae. See Cucumber.

\section{Grape}

Cottony maple scale, Pulvinaria vitis. This scale is often found on grape although it does not cause serious injury. See Maple.

Eight-spotted forester, Alypia octomaculata. The larvae of this insect often feed on grape leaves. See Virginia Creeper.

European fruit scale, Lecanium corni. This scale that infests many different kinds of trees and shrubs often occurs on grape vines. See Plum.

Grape berry moth, Polychrosis viteana. The grape berry moth is the cause of most of the wormy grapes throughout the United States and Canada, and often is responsible for a loss of from 25 to 50 per cent of the crop in the large vineyards. There are three broods each year, and the insect always passes the winter in the cocoon stage on damp and decaying leaves on the ground. The moths emerge the first of June and lay eggs on the stems of the blossom clusters, and the young caterpillars web together and partially devour the buds and blossoms. They continue feeding on the blossoms and newly-set berries, becoming full grown about July 1, when they are about three-eighths of an inch in length, and vary in color from dark green to purple, with light brown head. They then cut peculiar flaps in the leaf and fold them to form a cocoon or case in which to pupate. In two weeks the moths emerge, and have a wing spread of about half an inch. In color they are purplish brown with darker markings on the fore-wings. These moths lay eggs on the green berries, in which the young larvae bur- 
row and feed during July and August. Infested berries often show purplish spots and sometimes crack open. A larva may leave one berry and enter a second or third berry, fastening them together with a few silk threads. This second brood of caterpillars does the greatest damage, and the third brood larvae feed during September, sometimes in the ripening fruit.

Control measures are spraying with lead arsenate three times, the first application soon after the fruit sets, the second 10 days later and the third about the middle of July. Bagging the clusters in the small garden will protect them from injury. (See Fig. 39.)

Grape flea beetle, Haltica chalybea. This is a glossy greenish blue leaf beetle less than one-fifth of an inch in length, which eats the buds of the grapevine just as growth begins. It has caused severe injury in limited areas in the eastern half of the United States. The female beetles lay eggs under the edges of loose bark, and the young grubs feed upon the upper surface of the leaves in June and July, partially skeletonizing them. The old beetles hibernate under loose bark, trash, and wherever they can find protection.

There is a single annual generation. Perhaps the best treatment for the control of this beetle is to keep the vines sprayed with lead arsenate between June 15 and July 15 , or after the fruit has set. This will help control the grape berry moth, Japanese beetle and other leaf-feeding insects.

Grape leafhopper, Erythroneura comes. Both nymphs and adult leafhoppers suck sap from the under sides of the leaves, which soon turn brown. There are two broods each year and in late fall the adults seek protection in woodlands, brush, weed or grass areas, where they pass the winter. The adult is only an eighth of an inch long, and is white peculiarly marked with yellow and red. In large vineyards, boom sprayers are used to apply nicotine sulfate and soap to the under sides of the leaves to kill the nymphs.

Grape phylloxera, Phylloxera vitifoliae. This insect is an aphid having two forms; one is a yellow wingless form causing nodules on the roots, and the other forms galls on the leaves. There may be six annual generations of the root form and from five to seven generations of the gall-making form

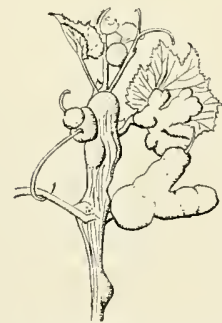

Figure 37. Grapevine tomato gall.

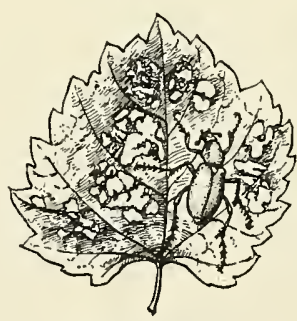

Figure 38. Rose chafer.

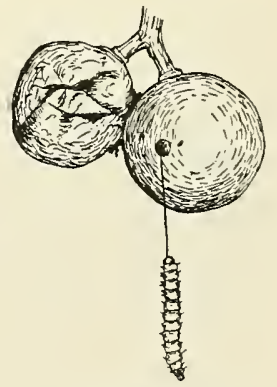

Figure 39. Grape berry moth.

on the leaves. This insect is extremely destructive to the European varieties derived from Vitis vinifera, and such varieties can be grown here only when grafted on the roots of American species of grape.

Grape plume moth, Oxyptilus periscelidactylus. The larva of this moth webs together the tender terminal leaves and feeds inside the nest. It does not injure the shoot but feeds on the leaves. It is light green with white hairs and reaches a length of about half an inch. It matures late in June 
and the pupa is fastened to a leaf. In a week there emerges a yellowish brown moth with deeply cleft wings or "featherwings." This insect causes little real injury, though some growers are alarmed over it. Pinching and crushing the larvae in the webbed leaves is perhaps the best measure of control.

Grape root worm, Fidia viticida. In some portions of the eastern United States the grape root worm is considered the most destructive insect pest of the grape. The adult is a small grayish brown leaf beetle which eats peculiar chain-like holes in the leaves in July, and the larvae or grubs devour the small root fibers and eat off the bark of the larger roots and main stem beneath the surface of the ground. Badly injured vines have yellow leaves that fall prematurely, the fruit withers and drops, and in severe cases the vines die. The beetle is about one-fourth of an inch in length. The eggs are laid in batches under the loose bark on the old canes. The young grubs drop to the ground, enter through cracks or crevices and make their way to the roots where they feed for the remainder of the season. They live in the soil as larvae through the winter, continue feeding in the spring and late in May or early in June ascend to the upper two or three inches of soil and make earthen cells in which they pupate. There is one generation each year.

The measures of control are as follows: Spraying the foliage with lead arsenate to kill the beetles, and cultivating the surface of the soil frequently in June to break open the pupal cells and expose the pupae to be devoured by ants, birds, and other natural enemies.

Grape scale, Aspidiotus uvae. This scale occurs on the old canes, especially under the edges of the loose bark. It is not very injurious. The shells are circular or somewhat elliptical, gray or yellowish brown, with a pale yellow exuvial spot with a whitish nipple at one side of the center. There is a single generation each year; the winter is passed by the nearly matured females, which complete their development in the spring, and in May and June give birth to living young.

In case a remedy is needed, a dormant spray of lime-sulfur is recommended.

Grapevine tomato gall, Lasioptera vitis. This is a swollen or tumid deformation of the new growth which takes many forms and may involve the leaves, tendrils, blossom buds, and the terminal shoot itself. The eggs are laid in the tissues by a midge or small fly and the galls contain cells in which pinkish maggots or larvae develop. There is one generation each year.

There is no known measure of control other than cutting off and burning the galls. (Fig. 37.)

Light-loving grapevine beetle, Pachystethus lucicola. This is a fairly common beetle about one-fourth of an inch in length, usually with lightbrown wing-covers without markings. Another form is purplish black and both forms may be found feeding upon grape, Virginia Creeper, and sometimes beans. There is one generation each year and the winter is passed by the partially-grown larvae in the soil, where they feed upon grass roots.

It is only when abundant that any control measures are necessary, and then the foliage should be sprayed with lead arsenate.

Japanese beetle, Popillia japonica. When abundant this beetle may cause severe injury by feeding upon the tender terminal leaves of grape. See Rose.

Rose chafer, Macrodactylus subspinosus. The rose chafer is often a serious pest of grape and sometimes devours the blossom buds, blossoms and newly-set fruit in addition to riddling the leaves.

Spraying with self-boiled lime-sulfur and lead arsenate, or with sweetened lead arsenate will probably lessen the injury. See Rose. 
Sphinx caterpillars. There are several kinds of horn worms or sphinx caterpillars that of ten feed upon grape leaves. Some of these are the abbot sphinx, Sphecodina abbotii, the hog caterpillar, Ampelophaga myron, and two less common species, the achemon sphinx, Pholus achemon, and the Pandorus sphinx, Pholus pandorus.

Hand picking is the only remedy in common practice, but where the vines are sprayed with lead arsenate, these caterpillars cannot live upon them.

Spotted grapevine beetle, Pelidnota punctata. This is a light-brown glossy beetle marked with black spots. The beetles feed upon grape and if numerous may do some damage.

\section{Grass}

Aphids. Several species of aphids infest grass in fields and meadows. Some of these are Anoecia querci, Hysteroneura setariae, Macrosiphum granarium, Rhophalosiphum prunifoliae and Toxoptera granimum.

Little can be done in the way of control except to cut the grass and make hay of it.

Armyworm, Cirphis unipuncta. In certain seasons grasses and grains are stripped of leaves and heads during July, by brown striped caterpillars, which when abundant strip entire fields and move like armies seeking other fields to devastate and inflict great damage. The caterpillars reach a length of about one and one-half inches, and feed chiefly at night and in cloudy weather. The moth has a wing spread of one and three-fourths inches, with brown fore-wings, and gray hind wings paler at the base. There are two generations in New York State, and the late brood of larvae hibernates and feeds in April and May. The most injurious brood appears in July.

The advance of the worms may be impeded by plowing a deep furrow around the infested field or across the line of march turning the soil towards the invaders. The worms may be killed by sprinkling them with kerosene, or feeding them poisoned bran mash. Grass or grain which has not become infested may be protected by spraying strips with lead arsenate. (See Fig. 40.)

Fall armyworm, Laphygma frugiperda. This insect injures grass, millet, and lawns in somewhat the same manner as the armyworm, except that it is more apt to be confined to millet and lawns and the injury occurs in September instead of July. See Lawns.

Grasshoppers. Several species of grasshoppers are often sufficiently abundant to cause great injury by feeding upon the grasses and grains. The principal offenders are the red-legged grasshopper, Melanoplus femurrubrum; the lesser locust, $M$. atlanis; and the two-striped grasshopper, M. bivittatus.

In the western states where severe injury occurs, grasshoppers are controlled by distributing poisoned bran mash in the infested fields.

Leafhoppers. There are many species of leafhoppers that feed upon grass, the most abundant being Deltocephalus inimicus and Phlepsius irroratus.

There is no remedy other than cutting the grass and making hay of it.

White grubs. The grubs of several species of May or June beetles, Phyllophaga sp. feed upon the roots of grass in fields and meadows. In occasional seasons areas of two acres or more in extent have the grass killed because the roots are eaten off by the grubs. The turf may be rolled up like a carpet, and many holes are made by skunks and other animals that feed upon the grubs. Such a condition is more apt to exist on dry fields than in wet meadows. The beetles are solid brown and about threefourths of an inch long. Most of these beetles require three full years for their development from egg to adult, and most of the injury to grasslands 
occurs during the second season of the grubs. Some of the more common species in Connecticut are Phyllophaga crenulata, $P$. hirticula, P. forsteri, $P$. fraterna and $P$. fusca.

Rotation of crops, fall plowing and thorough disk-harrowing the land will do much to prevent injury from white grubs. (See Figs. 41 and 42.)

\section{Hawthorn}

Aphids. Several species of aphids may occur on hawthorn, particularly Anuraphis crataegifoliae and Macrosiphum crataegi.

The remedy is to spray with nicotine solution and soap.

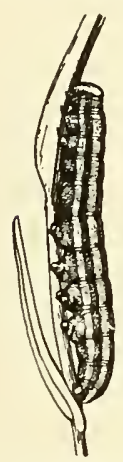

Figure 40. Armyworm.

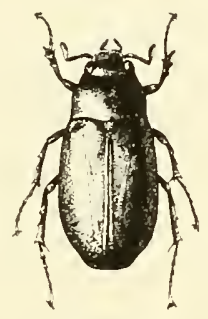

Figure 41. June beetle.

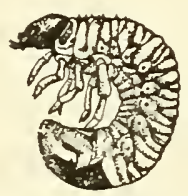

Figcre 42. TWhite grub. Larva of June beetle.

Apple and thorn skeletonizer, Hemerophila pariana. This insect feeds upon the leaves of hawthorn. See Apple.

Canker worms. Both the spring canker worm and the fall canker worm feed upon hawthorn. See Apple.

Gipsy moth, Porthetria dispar. The caterpillars feed upon the leaves of hawthorn. See Apple.

Hawthorn lacebug, Corythucha cydoniae. This is a small lacebug that lives on the under side of the leaves.

Spraying with nicotine sulfate and soap is a good remedy.

Round-headed apple borer, Saperda candida. This insect is also a borer in hawthorn. See Apple.

Thorn limb borer, Saperda fayi. The larva of this beetle is a borer in the smaller branches and twigs of hawthorn, and causes swellings about an inch long with four or five longitudinal scars. Infested twigs break off in the wind. The beetle is half an inch long, brown, with two white crescent-shaped spots near the middle of the wing-covers and two smaller circular spots near the apex. The thorax has a white stripe on each side extending upon the base of the wing-covers. There is one annual generation and the beetles appear in June.

The only control measure to be recommended is to remove and burn the infested twigs.

\section{Hazel}

Aphid, Macrosiphum coryli. This aphid infests the leaves of hazel. 
Hazel bud gall, Eriophyes avellanae. This gall, caused by a mite, is rather common on Corylus americana. Usually it involves a terminal bud, but sometimes affects a lateral bud.

Hazel nut weevil, Balaninus obtusus. This is one of the smaller nut weevils having a length of between one-fourth and one-third of an inch. It varies in color from ash-gray to brown, and has darker dorsal markings. The beetles appear in June, and the females deposit eggs in the developing nuts. The infested nuts fall early. There is one annual generation.

Control measures have not been perfected.

Hazel whitefly, Trialeurodes coryli. This whitefly infests the leaves of both Corylus americana and $C$. rostratus.

It is rarely abundant and control measures are probably not necessary.

\section{Hemlock}

Hemlock scale, Aspidiotus abietis. This is a gray circular scale that occasionally infests the leaves, and causes them to turn yellow, giving the tree a sickly appearance.

Hemlock webworm, Gelechia abietisella. The larva of this insect webs together a few leaves and feeds upon the leaves inside the web. The larva is less than one-fourth of an inch in length and some individuals are bright green and others are brown though structurally alike. The moth is whitish with pale brown tips and with darker brown cross bands on the costal margin. It has a wing spread of less than half an inch. Evidently there is one brood each season and the eggs are laid in June. The larvae apparently live over winter in the webs in a nearly full-grown state.

Probably a spray of lead arsenate will help control this insect.

Pine leaf scale, Chionaspis pinifoliae. This scale occasionally infests hemlock. See Pine.

Spotted hemlock borer, Melanophila fulvoguttata. The larva of this destructive beetle is a borer under the bark of living, injured, and dying hemlock and spruce trees. The adult beetle is about three-eighths of an inch long, flattened, and is dark bronze in color with three small whitish spots on each wing-cover. The larva is one of the so-called flat-headed borers which make sinuous interlacing flattened galleries in the inner bark and sapwood, thus girdling the tree. The beetles are abroad in June and July. Presumably there is one brood each year.

The only known measure of control is to cut the infested trees and to burn the bark in late winter or early spring.

Spruce mite, Paratetranychus ununguis. This mite infests nearly all kinds of conifers and may be expected to occur on hemlock. See Spruce.

\section{Hibiscus}

Corn ear worm, Heliothis obsoleta. Although usually a pest of corn, the caterpillars sometimes injure flowering plants, including hibiscus. See Corn.

\section{Hickory}

Aphids. Several species of aphids are found on hickory. Some the more common are Monellia caryae, M. caryella and $M$. costalis on the leaves. On the twigs there occurs a larger ash-gray aphid with triangular black spots on the thorax of the wingless forms; the winged form has the thorax all black. This is Longistigma caryae.

If control measures are needed, a spray of nicotine sulfate and soap will kill the aphids.

Fall webworm, Hyphantria cunea. The fall webworm commonly infests hickory trees. See Pear. 
Hickory bark beetle, Scolytus quadrispinosus. This beetle is the most destructive enemy of hickory trees in Connecticut and breeds under the bark. The female in July makes a vertical tunnel about an inch long in the inner bark and sapwood, with a row of pockets along each side. In each pocket she deposits an egg. The grubs hatching from these eggs commence to tunnel in a direction at right angles to the parent gallery, but the larval galleries, though narrow at first, increase in width as they extend, and those at the ends of the parent gallery are deflected so as not to run into the other galleries. Even a few such brood galleries may girdle the branch. They usually begin in the upper part of the tree. The adult is a small brown or black beetle, one-fifth of an inch long with abdomen truncated at the apex and bearing four short spines. The beetles emerge in June and July through round holes resembling shot holes and eat at the bases of the leaf stems, causing many leaves to turn brown in July. Some drop and others hang upon the trees. There is one generation annually.

All severely injured trees should be cut and burned before the beetles emerge. A spray of lead arsenate the latter half of May will prevent some of the foliage injury. Choice shade trees should be kept in a thrifty condition and given plenty of water in periods of drought.

Hickory gall aphid, Phylloxera caryaecaulis. This aphid forms galls in June on the leaf stems and new shoots. The hollow galls contain the young aphids. In July the aphids reach maturity and leave the galls,

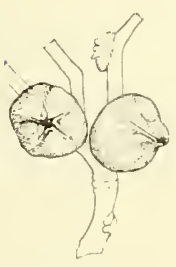

Figure 43. Gall of hickory gall aphid.

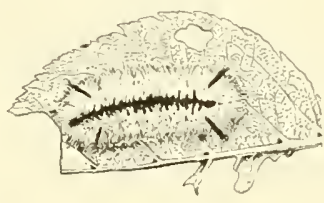

Figure 44.

Hickory tussock moth.

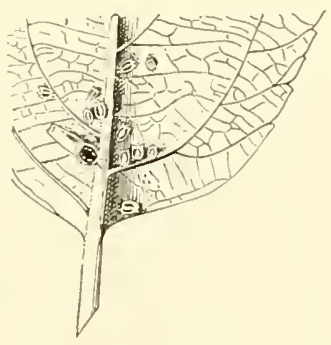

FIGURE 45.

Greenhouse orthezia.

which turn black. The galls are globular and cause much distortion to the shoots. Eggs remain over winter in the old galls and in crevices of the bark.

A spray of nicotine sulfate, two teaspoonfuls in a gallon of water, with soap and molasses added, made just before the buds swell is a satisfactory control. (See Fig. 43).

Hickory horned devil, Citheronia regalis. The appearance of the larva suggests the common name of this insect. It may reach a length of more than five inches and varies in color from green to reddish brown. There are two large black spots on the second thoracic segment and short black spines on each segment with longer black-tipped ones near the head which are called horns. It is never sufficiently abundant to be considered a pest, but occasionally it feeds on the leaves of hickory and other trees. The adult is called the regal moth and is one of our largest and most beatuful moths with a wing spread of five to five and one-half inches. The forewings are taupe gray with light red along the veins, with a number of oval buff spots. The rear wings are light red with buff spots.

Hickory leaf galls. There are several insect galls on hickory leaves, most of them being caused by midges or two-winged flies. Some of the 
more common are the hickory tube gall, Caryomyia tubicola; the hickory seed gall, C. caryaecola; the hickory onion gall, C. holotricha; the hickory peach gall, C. persicoides; and the hickory leaf gall, C. caryae. No remedy is known.

Hickory leaf roller, Eulia juglandana. The larva is yellowish green, about an inch in length and rolls hickory leaves in a characteristic manner and feeds upon them inside the rolls. The moth is dark brown with darker oblique bands on the fore-wings. Little is known of its life history or of its status as a pest.

Hickory tussock moth, Malisidota caryae. This insect feeds upon hickory and other tree foliage. The full-grown larva is about one and one-half inches in length, covered with white hairs, with a stripe of black hairs along the back, and two narrow pencils of black hairs at each end. The adult moth has a wing spread of about two inches, with fore-wings light brown marked with oval white spots and darker brown veins. The rear wings are light buff. The eggs are laid in patches on the under side of a leaf in July. There is one annual generation and the insect hibernates in gray cocoons fastened to trees, fences and other objects. Two similar species, II. tessellaris and II. maculata also feed upon hickory but are less common.

For control, spray with lead arsenate. (See Fig. 44.)

Painted hickory borer, Cyllene caryae. The larva of this beetle tunnels under the bark and in the sapwood of hickory. The beetles emerge in May and June and there is one annual generation. The beetle is about threefourths of an inch in length, blackish with yellow markings. There are three narrow cross-bands on the thorax, a W-shaped mark across the wingcovers near their base, and several other wavy cross-marks. The eggs are laid in crevices or under the edges of the bark and the young larvae tunnel partly in the bark and partly in the wood. The larvae become mature in from 10 to 12 weeks, and pupate in the wood in September and there hibernate until spring. Thrifty trees are seldom injured by this insect.

Cutting and burning infested trees and all slash is the usual measure of control. In choice shade trees one could inject carbon disulfide into the burrows and plug the openings.

Walnut caterpillar, Datana integerrima. The walnut caterpillar feeds upon hickory. See Walnut.

\section{Hollyhock}

Stalk borer, Papaipema nitela. The larva of this insect occasionally tunnels in hollyhock. See Dahlia.

Thistle butterfly or painted lady, Vanessa cardui. The caterpillar feeds upon the leaves of hollyhock, at first under a web, then on the upper surface of a leaf. Sometimes it webs together two or more leaves and lives inside. It reaches a length of about one and one-fourth inches. In color it varies from light green to light brown mottled with black, with a light dorsal stripe and with a yellow stripe along each side. It is covered with grayish spines. The butterfly has a wing spread of about two and one-half inches and is orange red with black and white markings. This butterfly is double-brooded in the northern states.

Hand picking and spraying with lead arsenate are the usual control measures.

\section{Horsechestnut}

White-marked tussock moth, Hemerocampa leucostigma. This insect has two generations each year, and spends the winter in frothy white eggmasses on the trees. The eggs hatch in late May and the caterpillars mature about July 1 and make their gray cocoons on the trees. Two weeks 
later the moths emerge and the females lay their egg-masses, usually on the old cocoons. The second brood larvae hatch in July and mature in August. The caterpillars reach a length of about one and one-half inches. They are striped lengthwise with brown and yellow, and are hairy, with four upright white tufts on the front half, two long pencils of black hairs near the head, and a similar one on the tail. There is a bright red spot just back of the head. The female is ash-gray without wings. The male has prominent feathered antennae with wings ash-gray with darker gray markings. It has a wing spread of about one and one-fourth inches. (See Fig. 47.)

Control measures consist of spraying the foliage with lead arsenate and in some cases removing and destroying the egg-clusters.

\section{Horse-Radish}

Horse-radish flea beetle, Phyllotreta armoraciae. This flea beetle is about one-eighth of an inch in length, black with yellowish wing-covers, except for a narrow black outer margin and a broader inner margin, the latter appearing as a central longitudinal stripe, broadest in the middle. This flea beetle feeds upon horse-radish and water cress. The females lay eggs on the petioles of the young leaves in May and the larvae burrow in the petioles, often killing some of the leaves. The insects hibernate as pupae in the ground and there is only one generation each year.

Spraying the foliage with lead arsenate is the remedy.

\section{Honeysuckle}

Aphids, Siphocoryne xylostei and Prociphilus xylostei. The former infests Tartarian honeysuckle, snowberry and parsnip, and the latter is a woolly species occurring in colonies on the twigs and curled leaves. They may be kept in check by spraying with nicotine sulfate and soap.

Honeysuckle leaf roller, Harpipteryx $x y$ lostella. The larva of this insect is a leaf roller of the Tartarian honeysuckle, and sometimes causes a very ragged appearance of the leaves. It is leaf-green with two chocolate median stripes and a lighter blue-green stripe on each side of the median stripes. It reaches a length of nearly three-fourths of an inch, thickest at the fifth abdominal segment, from which it tapers to a narrow head and tail. The cocoon is white, fastened to a leaf and is sharp-pointed at both ends. The moth is chestnut-brown, with cream-colored rear'margin on fore-wings. Tips of fore-wings are extended backward and form recurved hooks. Wing spread is about four-fifths of an inch.

Spraying with lead arsenate will prevent defoliation.

Honeysuckle sawflies, Abia americana and A. inflata. Climbing and bush honeysuckle are sometimes stripped of leaves by the larvae of these large sawflies. The larvae reach a length of about an inch, are dull gray with yellowish dorsal and latero-ventral stripes. There is a row of black spots along the back in the middle of a yellowish stripe. There is one annual generation. The insects winter as pupae in the ground and the adults emerge in April. They are medium-sized sawflies that resemble small bees. Both have brown-clouded fore-wings; americana has a metallic green abdomen, and inflata a black abdomen with yellow ring at base and silver pubescence on the rear margin of each segment.

An application of lead arsenate will protect the foliage.

Snowberry clear-wing, Hemaris diffnis. The larvae of this moth feed upon Tartarian honeysuckle. See Snowberry.

\section{Hyacinth}

Bulb fly, Merodon equestris. This fly also injures hyacinth. See Narcissus. 
Bulb mite, Rhizoglyphus hyacinthi. The bulb mite injures hyacinth. See Narcissus.

\section{Hydrangea}

Rose chafer, Macrodactylus subspinosus. The rose chafer sometimes feeds upon hydrangea. See Rose.

Tarnished plant bug, Lygus pratensis. This insect is often found on hydrangea. See Apple.

\section{Iris}

Aphids, Macrosiphum solanifolii and Myzus persicae. These aphids occasionally infest iris but cause little injury. In case they are present in abundance, a spray of pyrethrum-soap or nicotine sulfate will kill them.

Iris borer, Macronoctua onusta. This insect has a pinkish larva with brown head that tunnels in the rootstock of German iris, injuring or destroying many plants. It reaches a length of about one and one-half inches in late fall and pupates in the ground. The adult moth emerges in October. The moth has a wing spread of about two inches, and is brown with black markings on the fore-wings. The females lay eggs on the iris leaves. These eggs hatch in the spring and the young larvae tunnel in the stems and soon find their way into the rootstocks. There is one brood each year.

In early spring the leaves should be gathered and burned to destroy the eggs. Some authorities advise spraying the plants with lead arsenate in early spring. (Fig. 46.)

\section{Ivy, Boston}

Eight-spotted forester, Alypia octomaculata. The caterpillars feed upon the leaves of ivy. See Virginia Creeper.

Leafhoppers, Erythroneura comes, E. trifasciata, E. vitis, and other species and varieties that usually infest the grape are also found upon Boston ivy.

The best method of control is to spray the under surface of the leaves with nicotine sulfate and soap.

Sphinx caterpillars. Some of the sphinx caterpillars or hornworms that are found upon the grape occasionally occur on Boston ivy. See Grape.

\section{Ivy, English}

Bean aphid, Aphis rumicis. This aphid has been found several times on English ivy in Connecticut.

It may be controlled by spraying with nicotine sulfate and soap.

Mealybugs, Pseudococcus citri and P. adonidum. Mealybugs often infest English ivy in houses and greenhouses. See Lantana.

Soft brown scale, Coccus hesperidum. This scale infests English ivy and many other kinds of plants. See Fern.

White or oleander scale, Aspidiotus hederae. This circular scale infests the leaves and stems of various greenhouse plants including English ${ }^{*}$ ivy. See Oleander.

\section{Juniper}

Juniper scale, Diaspis carueli. See Cedar. 
Juniper webworm, Dichomeris marginellus. Low juniper plants in particular are infested by the juniper webworm which webs together the leaves and twigs. The larva is a light brown caterpillar, half an inch or less in length, which feeds upon the leaves in the webs. The moths appear early in June and have a wing spread of five-eighths of an inch, with forewings dark brown, and front and rear margins white.

Spraying with lead arsenate has given good results in Connecticut.

Spruce mite, Paratetranychus ununguis. The spruce mite injures juniper. See Spruce.

\section{Kale}

Turnip aphid, Aphis psendobrassicae. This aphid infests kale. See Turnip.

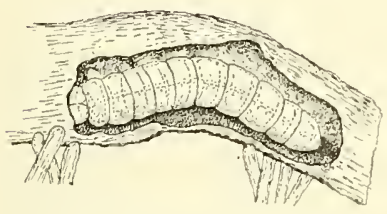

FIgURe 46. Iris borer.

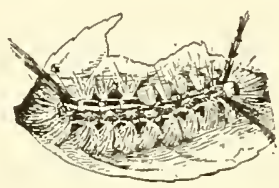

Figure 47. Caterpillar of white-marked tussock moth.

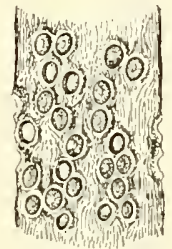

Figure 48 Pit-making oak scale.

Some of the insects that injure cabbage also feed upon kale. See Cabbage.

\section{Kohlrabi}

Cabbage aphid, Brevicoryne brassicae. This aphid also infests kohlrabi. See Cabbage.

In general the insects that injure cabbage also feed upon kohlrabi. See Cabbage.

\section{Lantana}

Greenhouse orthezia, Orthezia insignis. This curious insect sucks the sap and is common in greenhouses, especially on lantana and coleus. It is sometimes called the lantana bug. It is not fixed upon the plant but crawls about like a mealybug and there is usually considerable wax secretion.

This insect can be controlled by spraying with a strong nicotine sulfate and soap mixture, or with pyrethrum-soap. (Fig. 45.)

Mealybug, Pseudococcus citri. This and the long-tailed mealybug, $P$. adonidum, commonly infest a large number of greenhouse plants, especially begonia, coleus, croton, chrysanthemum, fern, geranium, heliotrope, lantana, oleander, and palms. Like the greenhouse orthezia, mealybugs are scales without armor, which crawl around upon the plants and do not become fixed like most scales. The long-tailed species resembles the other except that the long wax filaments suggest its name. Mealybugs have the habit of congregating in the leaf axils, along the veins and in the leaf-sheaths.

A strong spray of nicotine sulfate with soap or of pyrethrum-soap will hold mealybugs in check. (Fig. 55.) 


\section{Larch}

Larch case bearer, Coleophora laricella. The larva of this minute insect is a miner in the leaves. It reaches a length of about one-fifth of an inch and is dark reddish brown with a black head. The adult is a small ashgray moth having a wing expanse of three-eighths of an inch and bearing long fringe on the margins of the wings. The moths emerge late in May or early in June and lay eggs on the leaves. The young larva bores its way into the leaf and usually first tunnels out the distal half packing its excrement into the burrow in the mined leaf. By September the entire leaf has been mined and it cuts off the distal half, cleans out the basal portion and uses it as a winter case. Later it fastens the case to a twig where it remains through the winter. In spring the larvae dislodge their cases and go to the buds and feed upon the new leaves, until they are fully grown in May when they pupate on the branches. From two to three weeks later the moths emerge. There is only one annual generation.

A dormant spray of lime-sulfur in spring kills the larvae in their winter cases.

Larch sawfly, Lygaeonematus erichsoni. Larch leaves are often eaten by the larvae of this insect, which are dull gray or olive green above, pale green beneath, and nearly three-fourths of an inch in length when fully grown. There is probably one annual brood, and the larvae winter in their cocoons on the surface of the ground under the trees, and pupate the following spring. The adults emerge in May and the females cut into the new shoots to lay their eggs. The young larvae feed upon the leaves, at first cutting notches in the sides and the leaves soon wither and turn brown. Later they devour the entire leaf, and when abundant strip the trees. The adults are black sawflies, the female being nearly half an inch in length and the male smaller.

A spray of lead arsenate will prevent defoliation.

I Larch woolly aphid, Adelges strobilobius. This woolly aphid is present on larch foliage in June. Its life history is complicated, certain generations occurring on larch and others forming galls on spruce. An immature form hibernates on spruce and a different immature form winters on larch.

Choice larch shade trees when infested should be sprayed with nicotine sulfate and soap or with pyrethrum-soap.

\section{Larkspur}

Cyclamen mite, Tarsonemus pallidus. This mite causes severe injury to larkspur plants. It curls the leaves and prevents the development of the blossoms. See Cyclamen.

Stalk borer, Papaipema nitela. This insect injures an occasional flower stalk of larkspur. See Dahlia.

\section{Lawns}

Ants. There are several species of ants that commonly injure lawns. In general they may be destroyed by the use of carbon disulfide applied in holes made in the soil in the vicinity of the nests, or by placing poison bait of tartar emetic where ants will have access to it. Circ. 67.

Asiatic beetle, Anomala orientalis. This beetle is now present in the western part of New Haven and has injured many lawns. The larvae, or grubs, feed on grass roots just beneath the surface of the ground. The adults emerge in late June and July, and the females lay eggs in the soil, at a depth of about six inches. These eggs hatch in from three to four weeks and the young grubs ascend and feed upon the grass roots near the surface. In late October and November they descend to a depth of a foot to hiber- 
nate. In April they ascend to the surface and resume feeding until the first of June when they go down to a depth of about six inches to pupate. They pass through a prepupal period of about six days, then pupate, and two weeks later the adults emerge. There is one generation each year, although a few individuals do not transform with the others, but require two years for their development. The beetle is about three-eighths of an inch in length and varies greatly in color and markings. Some have light brown wing-covers without markings and a small proportion are uniformly purplish black. Many of them have black patterns on the wing-covers and fall between these two extremes. Most of them have yellowish margins on the thorax with solid black in center, but some have wider margins with the central black area divided lengthwise to form two smaller black areas. Apparently the beetles do not fly very much or very far nor feed very extensively, but are often found in roses and hollyhock blossoms and in the turf.

To protect the lawns from injury lead arsenate at the rate of 3 pounds to 100 square feet of lawn surface should be applied. In remaking the lawn the poison may be distributed over the surface and raked into the upper 2 inches of soil. In case the lawn is infested, but the grass not badly injured, the poison should be mixed with water and sprinkled evenly over the lawn and water from the hose applied through a medium nozzle in order to wash the poison off the grass blades into the soil. The lawn should not be flooded and there should be no run-off. Bulletin 30. and Circular 62 of this Station deal with this insect.

Asiatic garden beetle, Aserica castanea. The grubs of this imported insect also feed upon the roots of grass and are responsible for considerable injury to lawns on Long Island, Westchester County in New York, and in New Jersey. This insect is present at several points in Connecticut, but thus far has not become sufficiently abundant to be noticeable or to devastate lawns. The life history is similar to that of the Asiatic beetle, but the adults are much more active in flight and are attracted to lights. They are more injurious as adults and feed at night on many kinds of plants, especially aster, barberry, bean, cherry, chrysanthemum, currant, dahlia, geranium, catalpa and seedling conifers. During the day the beetles hide in the soil around the plants and are seldom seen unless one knows where to find them. The beetle is about three-eighths of an inch in length, dull cinnamon brown, with wing-covers longitudinally and finely striated.

Spraying the food plants with lead arsenate, and treating the lawns with the same poison as described under Asiatic beetle will afford an effective measure of control.

Chinch bug, Blissus leucopterus. Dead and brown patches on lawns, although more commonly caused by fungi, are occasionally caused by great numbers of this insect. It is only about one-seventh of an inch long, but though small is conspicuous because it is black and white. It is said to be single-brooded in New England, and is seldom noticed except in connection with dead patches on lawns where the bugs have injured the grass by sucking the juices.

Such patches should be sprayed with soap and water or with nicotine sulfate.

Corn root webworm, Crambus caliginosellus. Lawn grass is sometimes injured by this webworm, which feeds in tube-like cases.

The grass may be protected by spraying with lead arsenate and nicotine sulfate. See Corn.

Fall armyworm, Laphygma frugiperda. Occasionally lawns are infested by hundreds or thousands of brown striped caterpillars that soon devour every green blade of grass. Such an outbreak occured in New Haven, Stonington, and on the front lawn of Branford House, Groton, in September, 1912. There are three broods each year in Nebraska and there are at 
least two broods here. The insect hibernates as a pupa in the soil. The eggs are laid upon the grass leaves; they soon hatch and the larvae feed upon the grass, reaching maturity in about a month, They are then about one and one-half inches long and striped lengthwise with narrow yellow and brown stripes. They pupate in the soil. The first brood of moths emerge in May and June, the second in July and early August, and the third in September. They have a wing spread of about one and onefourth inches, with fore-wings grayish brown, and rear wings pearly white with narrow brownish margins. This insect also feeds upon several different kinds of vegetables.

Infested areas on lawns may be sprayed with lead arsenate and nico. tine sulfate.

Japanese beetle, Popillia japonica. The grubs of this insect feed upon grass roots in lawns and golf greens and may be controlled with lead arsenate the same as the Asiatic beetle. See Rose.

White grubs, Phyllophaga sp. White grubs feed upon grass roots and may injure lawns. See Grass.

\section{Lettuce}

Aphids. Several species of aphids may occur on lettuce. Two of these are Macrosiphum sonchi, and Amphorophora lactucae, which are found on the leaves. Another species, Rhizobius lactucae, is a yellowish form occurring upon the roots.

Perhaps the best treatment is nicotine sulfate and soap or pyrethrumsoap sprayed upon the under side of the leaves. For the root forms the spray material can be poured into holes in the soil close to the infested plant.

Cutworms. Cutworms sometimes eat off young plants. See Tomato.

Garden slugs. The leaves of lettuce and other garden plants are often eaten by slugs, which are mollusks closely related to snails, but do not have any shells. At least two species are troublesome. The common one is the gray field slug, Agriolimax agrestis, and the other a more striking species is the giant or spotted garden slug, Limax maximus. Slugs feed at night on the tender leaves, eating notches in the margins or holes through the leaves. During the day they hide under rubbish, and they leave a slimy trail wherever they crawl.

Where the leaves are not to be used for food they may be sprayed with lead arsenate. As a rule the slugs do not like to crawl through dry caustic material, and beds may be protected by surrounding them with hydrated or air-slaked lime, fine coal ashes or soot.

\section{Lilac}

Lilac borer, Podosesia syringae. The larva is a borer in the stems of lilac and privet. It is white or yellowish with dark brown head. The moths emerge late in May and the females lay eggs in patches on roughened places in the bark. The larvae tunnel in the solid wood and sometimes in the pith for a distance of eight or ten inches. They also cut across the grain so that the branch breaks over. The larva pupates in the burrow after cutting a passageway to the bark. On emergence, the adult leaves the pupa case protruding from the burrow. There is one brood each year. The moth is a wasp-like clear-wing, with wing spread of from one to one and one-half inches.

The infested stem should be cut and burned. 
Lilac leaf miner, Gracilaria syringella. The larvae of this little moth begin their existence as miners in the leaves of lilac and privet, and when partly grown leave the mines, roll the leaf, and feed within the roll. The adult is a tiny ash-gray moth with narrow wings. There seem to be no records of control measures.

Oyster-shell scale, Lepidosaphes ulmi. This scale often infests lilac. Sèe Apple.

San José scale, Aspidiotus perniciosus. This scale frequently infests lilac. See Pear.

White peach scale, or West Indian peach scale, Aulacaspis pentagona. This scale infests lilac. See Peach.

\section{Lily}

Bulb mite, Rhizoglyphus hyacinthi. This mite injures lily. See Narcissus.

Lily aphids, Macrosiphum lilii and Myzus circumflexum. The former has black cornicles and the latter has a black horseshoe-shaped area on the dorsum of the abdomen. Both occur on the under sides of the leaves of various species of lily. Should they become abundant, the plants should be sprayed with nicotine sulfate or with pyrethrum-soap.

Mealy flata, Ormenis septentrionalis. This is one of the largest of the so-called lantern flies, which are sucking bugs. The eggs are laid in slits in the bark of twigs and covered with masses of a white wax secretion. This insect is found on a great variety of herbaceous plants and shrubs. There is one annual generation and the adults are present in August and September.

Although control measures are usually not necessary, the insect may be checked by spraying with nicotine sulfate and soap.

Stalk borer, Papaipema nitela. This borer is occasionally found in lily. See Dahlia.

\section{Lily-of-the-Valley}

Lily-of-the-valley weevil, Hormorus undulatus. The leaves of lily-ofthe-valley are often curiously notched by this weevil which eats into the leaf margins. No control measures can be recommended. (Fig. 49.)

\section{Linden}

Aphids. Therioaphis tiliae. This aphid, and doubtless other species, is found on the leaves of linden, sometimes in abundance.

A good remedy is to spray with nicotine sulfate and soap or with pyrethrum-soap.

Linden borer, Saperda vestita. Small-sized linden trees are often injured near the base by the larva of this insect. It eats out quite a large cavity, decay follows, and the tree soon breaks over. The larva is white and reaches a length of about an inch. It usually burrows near the ground sometimes going into the roots below the surface. There is usually a vertical gallery next to the bark and a cavity toward the center of the tree. The adult is a long-horned beetle about three-fourths of an inch in length, black, and covered with a dense appressed pubescence that is light olivegreen in color. Usually four small black spots are present just below the center of the wing-covers. The beetles emerge late in summer and feed somewhat on the leaves and tender shoots before laying eggs in the bark.

The usual control measures are removing and destroying the infested trees. Perhaps it is possible in certain cases to inject carbon disulfide or nicotine sulfate and soap into the burrow and plug the opening. 
Mulberry whitefly, Trialeurodes mori. The larvae or nymphs of this insect are often abundant on the under sides of the leaves of linden. See Mulberry.

White-marked tussock moth, Hemerocampa leucostigma. This insect occasionally defoliates large numbers of linden trees in cities. See Horsechestnut.

\section{Locust}

Aphids. The dwarf flowering locust or rose acacia is sometimes infested by the laburnum aphid, Aphis laburni, and the bean aphid, Aphis rumicis.

A spray of nicotine sulfate and soap will kill them.

Carpenter worm, Prionoxystus robiniae. Large galleries are often made in the trunks and larger branches of locust, ash, oak and maple by the carpenter worm, and large unsightly scars are evident wherever this insect occurs. Fortunately, this insect is seldom sufficiently abundant to cause severe injury. The moths emerge in June and July, and the females seem to prefer the vicinity of wounds for depositing eggs. The young larvae at first feed upon the inner bark, then burrow in the wood, chiefly excavating longitudinal galleries. The mature larva is about two and one-half inches in length, pink or flesh-colored, with brown head, thoracic and anal shields. The adult moth has a wing spread of about three inches and is gray with brown and black markings. It is believed that the life cycle of this insect extends over three years.

The larvae may be killed by injecting carbon disulfide into the burrows wherever sawdust is thrown out, and the openings should be stopped with putty, grafting wax, or some other plastic material. All wounds should be dressed and painted.

Locust borer, Cyllene robiniae. This is a beetle that closely resembles the painted hickory borer (See Hickory), but the adults appear in late summer instead of spring. It is very destructive to the black locust and has ruined many plantings. The eggs laid in the crevices of the bark in September soon hatch and the young larvae tunnel and hibernate in the outer bark, going into the wood the following spring and excavating the characteristic galleries. Evidence of infestation is sawdust falling down on the bark of the trunk and wet spots around the holes where the sawdust was ejected. Later ugly scars show where the wounds have partially healed. There is one annual generation, and the beetles are very abundant on goldenrod blossoms in September. In general, trees are not greatly injured after reaching a trunk diameter of about six inches.

Choice young trees may be protected by spraying the trunks and larger branches with a soluble arsenical poison combined with an oil as worked out by Dr. F. C. Craighead, who recommends the following formula: "Dissolve 4 ounces of sodium arsenite or arsenate in 5 gallons of water. Add one quart of miscible oil and agitate thoroughly." When sprayed upon the trunk, the material penetrates sufficiently to kill the borers when they feed upon the inner bark.

Locust leaf miner, Chalepus dorsalis. This small beetle less than onefourth of an inch long, feeds upon the leaves, and the larva is a miner in the leaves of locust. It is orange-red with a median black line along the back. It lays eggs in late May or early June on the under side of the leaves, in clusters of three to five. The larvae hatching from these eggs work their way into the leaf through the same entrance and live in a common blotch mine which may involve half the leaf, then they go to other leaves and make separate mines. The larval life lasts about three weeks, pupation takes place in the mine, and the beetles emerge a week or ten days later and hibernate. There is one brood each year.

Dr. Felt recommends spraying the foliage thoroughly as soon as developed, with lead arsenate. 
Locust treehopper, Vanduzea arquata. This treehopper is often very abundant on locust and it is possible to collect several hundred specimens from one tree. All are sucking the sap, and there are probably three or four broods a year in Connecticut. The adult is a small brown beechnutshaped insect less than one-fourth of an inch in length and chocolate brown in color.

Control measures are not known but there is a possibility that a concentrated spray of nicotine and soap or of pyrethrum-soap may kill the nymphs.

Locust twig borer, Ecdytolopha insiticiana. The larva of this insect tunnels in the small twigs of black locust, causing irregular swellings from one to three inches long. The borer emerges from the twig through a small exit hole usually between two thorns. The adult is a brown moth with wing spread of three-fourths of an inch. The fore-twings are chocolate brown crossed near the apex by two light gray bands forming a triangle.

The only treatment to be advised is to cut and burn the infested twigs.

Silver-spotted skipper, Epargyreus tityrus. This is one of the largest of the skipper butterflies, and the larvae feed upon the leaves of locust, especially the rose acacia. Each caterpillar fastens together with silk threads several leaflets making a case in which it lives and feeds. The caterpillar is leaf-green with brown head. The butterfly is brown with yellow and white quadrangular spots on the fore-wings. Both front and rear wings are sharp-pointed.

An application of lead arsenate will prevent defoliation.

\section{Magnolia}

Magnolia scale, Neolecanium cornuparoum. This is a brown soft scale that infests the lower branches of certain species of magnolia. Some entomologists consider it identical with the tulip tree scale, but as a rule the female scales are more elongated and smaller. There is one annual generation and the young appear in August, settle on the branches and hibernate as oval dark brown nymphs covered with a bluish waxy bloom.

It can be controlled by a dormant spray of lime-sulfur or miscible oil in the spring.

\section{Mangel}

Spinach leaf miner, Pegomyia hyoscyami. See Spinach.

\section{Maple}

Aphids. Several species of aphids infest maple trees. Periphyllus americanus occurs on sugar maple; P. lyropicta on Norway maple; and Drepanosiphum platanoides on sycamore maple. Drepanaphis acerifoliae is found on both sugar maple and silver maple.

The remedy is to spray with nicotine sulfate and soap.

Canker worms. Canker worms sometimes feed upon maple trees. See Apple.

Cottony maple scale, Pulvinaria vitis. This is a brown, oval, soft scale on the bark of the branches of silver and red maple in winter, but in June the large egg-sacs are formed, and their wax covering resembles a tuft of cotton. The young crawl in July and some of them live for a time on the leaves, but return to the twigs to pass the winter.

The best means of control seems to be a spray of miscible oil, one part in 15 parts of water, applied in early spring. However, sugar maple trees should not be sprayed with oil mixtures on account of danger of injury. (Fig. 52.) 
Gall mites. On maple leaves there are several forms of galls caused by mites. Some of the more common of them are the maple leaf spot gall, Cecidomyia ocellaris, on red maple; the maple bladder gall, Phyllocoptes quadripes, and the maple spindle gall, Phyllocoptes aceris-crumena on silver maple; and the gouty vein gall, Dasyneura communis, on sugar maple.

Experiments show that the maple bladder gall can be controlled by a dormant spray of lime-sulfur in early spring.

Green-striped maple worm, Anisota rubicunda. The caterpillars of this insect feed upon maple foliage, occasionally defoliating trees. When full grown it is about one and one-half inches in length, pale yellowish green, striped lengthwise with narrow light green and darker green stripes. There are two black spines on the second segment back of the head. The moth emerges in June, has a wing spread of about two inches, is pale pink and a broad pale yellow band crosses each fore-wing diagonally.

Spraying with lead arsenate will prevent defoliation.

Leopard moth, Zeuzera pyrina. The leopard moth is sometimes a borer in maple. See Elm.

Maple borer, Glycobius speciosus. This is the most destructive pest of the sugar maple. It is a beautiful black beetle with brilliant yellow decorations, including a W-shaped mark across the base of the wing-covers. It is about an inch in length and emerges in July. The female lays eggs in slits in the bark, and the young larvae tunnel in the inner bark and sapwood, hibernate in a chamber excavated in the sapwood, and the following spring cut large galleries in various directions, though usually in a spiral course upward and partly around the trunk. Sometimes two or more borers in a tree may completely girdle the trunk and the tree break over. They hibernate the second winter in chambers four inches from the bark. Two years are required to complete the life cycle. Generally the tree in its new growth attempts to heal or grow over the wound and results in a series of scars and ridges that show prominently on the trunk.

Choice shade trees should be examined carefully at least twice a year, in September and May, for sawdust on the bark. When a burrow has been discovered the grubs may be cut out, killed by running a wire into the burrow, or by injecting carbon disulfide or strong nicotine sulfate. The opening to the burrow should then be closed. (Fig. 50.)

Maple leaf scale, Pulvinaria acericola. This scale closely resembles the cottony maple scale to which it is closely related, but differs from it in that the egg-sacs are formed on the leaves instead of on the bark. This insect is not very abundant, but occurs on the sugar maple. The eggs hatch in late May or early June and the scales live upon the leaves until October when they migrate to the trunk where they hibernate on the bark.

If control is necessary a dormant spray of nicotine sulfate and soap or of lime-sulfur will probably prove effective.

Maple leaf-stem borer, Priophorus acericaulis. In certain years unde1 sugar maple trees one may see on the ground the last of May many fallen green leaves with their stems severed a half inch or less from the blade. The blades drop first and a few days later the stems fall. The insect responsible for this injury is a small sawfly that lays an egg in the leaf stem and the larva tunnels in the stem and just before maturing cuts it off. The larva drops and enters the ground to pupate and remains there until the following spring.

No control measures have been discovered.

Maple sesian, Sesia acerni. The larva of this clear-wing moth is a borer in maple trees, especially around wounds. There is one generation each year. The moth has a wing spread of about an inch; both fore and rear wings are transparent with narrow purplish margins, tips of forewings pale yellow, discal mark large and black. 
All trees should be kept thrifty and protected from mechanical injuries. Wounds should be dressed and cut surfaces coated with tree paint or carbolic acid emulsion during May.

Norway maple seed pod borer, Nepticula sericopeza. This insect injures and cuts off the leaves of Norway maple in a manner quite similar to that of the sawfly borer in the leaf stems of sugar maple. In this case the adult is a tiny moth and it commonly infests the seed pods and sometimes the leaf stems, causing many leaves to drop.

There is some evidence to show that the insect may be partially controlled by a spray of nicotine sulfate, soap and molasses applied in May.

Oyster-shell scale, Lepidosaphes ulmi. The oyster-shell scale occasionally infests maple and many other trees. See Apple.

Saddled prominent, Heterocampa guttivitta. The caterpillars of this insect occasionally become so abundant as to defoliate large areas of wood. land, especially beech, birch and maple. See Beach.

Terrapin scale, Lecanium nigrofasciatum. This small, reddish, oval, convex scale occurs on the small twigs of hard and soft maple often killing them. It varies from one-sixteenth to one-eighth of an inch in length and is usually reddish-brown mottled with black. Eggs are deposited in June under the old shells and there is one generation each year.

We must depend on a dormant spray to control this insect. Miscible oil 1 part in 15 parts water, may be applied in early spring to silver and red maples, but on hard maples it is safer to use nicotine sulfate and soap. (Fig. 53.)

White-marked tussock moth, Hemerocampa lencostigma. The caterpillars of this insect feed upon maple foliage. See Horsechestnut.

Woolly maple leaf scale, Phenacoccus acericola. This scale infests sugar maple, and there are said to be three generations each year. On the under sides of the leaves in summer may be seen masses of white wax one-fourth inch or more in diameter, resembling tufts of cotton or wool containing the living or dead female and about 500 eggs. When mature the males crawl

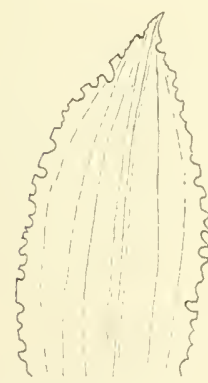

Figure 49. Lilyof - the - valley injured by Hormorus undulatus.

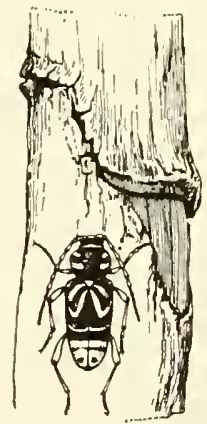

Figure 50. Maple borer.

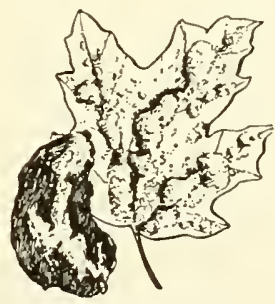

Figure 51.

Woolly maple leaf scale.

into the crevices of the bark and transform in white cottony wax cocoons. The adults emerge two weeks later. At the approach of winter the immature females crawl into the crevices of the rough bark of trunk and branches, and there secrete wax to form protecting cases in which they pass the winter. They often emerge on warm days and crawl about the bark. The white woolly cases are always noticeable in the crevices of the bark at the 
base of the larger branches and on the upper portion of the trunk on infested trees.

This insect can best be controlled by a dormant spray in late winter or early spring. Good results have been obtained with liquid lime-sulfur, 1 part in 9 parts of water with a pint of nicotine sulfate added to each 100 gallons of the mixture. (Fig. 51.)

\section{Marguerite}

Marguerite fly or chrysanthemum leaf miner, Phytomyza chrysanthemi. This leaf miner evidently prefers the leaves of marguerite and commonly infests them, but also sometimes injures chrysanthemum. The eggs are laid singly within the leaf by a gray fly about one-twelfth of an inch in length. The eggs hatch in about five days and the larvae mine in the leaves, become mature in about 18 days and pupate in the mines. About two weeks later the flies emerge.

As a control measure, a spray of nicotine sulfate, 1 part in 500 parts of water or of nicotine oleate applied at intervals of about 10 days has been recommended.

\section{Melon}

Melon aphid, Aphis gossypii. This aphid infests many different kinds of plants both in the field and in greenhouses, but it is particularly troublesome on cucurbits. It generally makes its appearance in scattered places in the field late in the summer and soon becomes abundant on the under sides of the leaves. These soon curl and the vine becomes too stunted to produce a crop, or perhaps wilts and dies.

Treatment is difficult, but the aphids may be killed by dusting heavily with nicotine dust applied on a warm day. Sometimes the heavily infested hills or areas can be covered lightly with a cloth and the dust blown underneath the cloth, which will hold the nicotine fumes long enough to kill the aphids and make the treatment more effective than it would be on open plants.

Melon worm, Diaphania hyalinata. Immature melons are sometimes infested by mottled greenish yellow caterpillars an inch or so in length, that burrow in the green fruit causing early decay. The moth has a wing spread of from one to one and one-fourth inches, and has triangular transparent wings with brown front and lateral margins. There are three annual generations in North Carolina. The first brood caterpillars feed largely upon the foliage and cause only slight injury to the crop.

Many of them can be killed by spraying the leaves with lead arsenate. Summer squashes should be planted near as a trap crop. All vines and waste fruits should be gathered and destroyed as soon as the crop is harvested.

Pickle worm, Diaphania nitidalis. The pickle worm also infests melons and other cucurbits. See Cucumber.

Potato flea beetle, Epitrix cucumeris. This flea beetle frequently injures young melon plants. See Potato.

Striped cucumber beetle, Diabrotica vittata. This beetle often injures young melon plants. See Cucumbers.

\section{Mignonette}

Cabbage looper, Autographa brassicae. The caterpillars sometimes feed upon mignonette. See Cabbage.

Corn ear worm, Heliothis obsoleta. The caterpillars when very abundant occasionally feed upon mignonette. See Corn. 


\section{Millet}

Armyworm, Cirphis unipuncta. This insect occasionally appears in great numbers and feeds upon grains and grasses of all kinds. See Grasses.

European corn borer, Pyrausta nubilalis. The European corn borer infests the larger stems of the grains and millet. See Corn.

\section{Mock Orange}

Aphids. The bean aphid, Aphis rumicis, and the spinach aphid, Myzus persicae, sometimes infest the tender shoots.

A spray of nicotine sulfate will kill them.

Leaf miner, Agromyza melampyga. The larva of this fly at first makes a curved linear mine in the leaf, but later the distal end of the mine expands into a blotch an inch or less in length and half as wide.

.Control of this miner is not understood.

\section{Morning Glory}

Leaf miner, Bedellia somulentella. The larva of this small moth makes a serpentine mine in the leaves, sometimes involving a large proportion of the leaf tissue. When mature it emerges from the mine, transforms, and suspends its slender angular cocoon from the leaf by a few silk threads. In a few days the small gray moth emerges.

Control measures are unknown.

Tortoise beetles. The leaves of Convolvulus and Ipomoea are sometimes eaten by tortoise beetles, especially Chelymorpha cassidea, Chirida guttata, Deloyala clavata and Metriona bicolor.

Usually control measures are unnecessary, but in case severe injury is feared, a spray of lead arsenate may be applied to protect the foliage.

\section{Mountain Ash}

Round-headed borer, Saperda candida. Mountain ash trees are sometimes severely injured by this insect. See Apple.

San José scale, Aspidiotus perniciosus. This scale infests mountain ash. See Pear.

Scurfy scale, Chionaspis furfura. This scale also occurs on mountain ash. See Pear.

Woolly aphid, Eriosoma lanigera. The bluish white woolly colonies of this aphid are often seen on the leaves and branches of mountain ash. See Apple.

\section{Mountain Laurel}

Mulberry whitefly, Tetraleurodes mori. In certain localities the under sides of the leaves of mountain laurel become literally covered with the nymphs of this insect. See Mulberry.

Rhododendron lacebug, Stephanitis rhododendri. This lacebug commonly infests mountain laurel in nurseries and ornamental plantings. See Rhododendron.

\section{Mulberry}

Hickory borer, Cyllene caryae. This insect is also a borer in the trunk of mulberry. See Hickory.

Mulberry whitefly, Tetraleurodes mori. This whitefly was named from the mulberry presumably because mulberry leaves are commonly infested 
and a favorite host, although the insect occurs on many other kinds of trees and shrubs. The oval nymphs or larvae occur on the under sides of the leaves, and are dark brown or black, fringed with marginal white wax rods. The adults resemble tiny moths and are white or yellow with forewings spotted with red and brownish black.

Usually control measures are not employed, but a spray of nicotine sulfate will probably destroy the insects.

\section{Narcissus}

Bulb fly, Merodon equestris. The maggot of this fly infests the bulbs and ruins them. There is only one maggot in a bulb, and the insect has one generation each year. The larva hibernates in the bulb, and pupation occurs in the spring in the old burrow or nearby in the soil. The adults appear in early summer and lay oval white eggs near the base of the leaves or on exposed portions of the bulbs. The maggot is a yellow or dirty white larva without legs and is about three-fourths of an inch in length. The fly is about half an inch long, black, and banded with yellow or gray, is hairy and resembles a bumblebee.

There is no remedy other than to remove and burn the infested plants.

Bulb mite, Rhizoglyphus hyacinthi. This mite injures nearly all kinds of bulbs, and Easter lily plants in greenhouses have been severely injured. The mites breed continuously in greenhouses or wherever the temperature and moisture are sufficiently high, and it is possible for 10 or more generations to mature in a year. When the conditions become unfavorable to the mite, such as lack of food or moisture a resistant stage called hypopus is formed, adapted for migration to fresh food supplies.

The control measures are: Burn all soft and decayed bulbs; store bulbs at about $35^{\circ} \mathrm{F}$.; immerse all infested bulbs for 10 minutes in nicotine sulfate, 1 part in 400 parts water, at a temperature of $110^{\circ} \mathrm{F}$., or 2 per cent formalin solution for the same time and temperature. Bulletin 225 of this Station describes the life history and control of this pest.

Lesser bulb fly, Eumerus strigatus. This fly is also a pest of onion, but narcissus is the plant most severely injured by it. It is believed that there are two generations each year. The flies appear in May and June and lay eggs at the base of the leaves. The larvae find their way to the tip of the bulb and then go downward into the interior. As many as 77 larvae have been found in a single bulb. When fully grown these maggots are between one-third and one-half inch in length, wrinkled and dirty grayish yellow in color. They pupate in August in the bulb or in the soil near it. Certain larvae hibernate in the bulbs, but these are thought to be the second generation, from which flies emerge the following spring. The fly is about onethird of an inch long, and has gray wings, and a black abdomen marked with three white crescent-shaped bands.

The only known measure of control is to gather and burn the infested plants.

\section{Nasturtium}

Bean aphid, Aphis rumicis. This aphid frequently infests nasturtium plants. See Bean.

Serpentine leaf miner, Agromyza pusilla. The larva of this fly makes a serpentine mine in the leaf of nasturtium. Also the turnip leaf miner, Scaptomyza flaveola, and the columbine leaf miner, Phytomyza aquilegiana (See Columbine) have been recorded as occasionally infesting nasturtium.

There is no remedy other than destroying the infested leaves.

\section{Oak}

Aphids. Several species of aphids occur on the various species of oak in Connecticut. Longistigma caryae occurs on the twigs, and Anoecia querci, Myzocallis discolor and M. punctatellus are found upon the leaves. 
Control measures are necessary only in case of severe infestation when a spray of nicotine sulfate and soap should be applied.

Broad-necked prionus, Prionus laticollis. The grub of this beetle is a borer in the roots and stumps of oak and several other kinds of trees. It is a white fleshy grub without legs and when full grown reaches a length of nearly three inches. The adult is a dark brown, long-horned beetle about one and one-half inches in length, and emerges in July.

No control measures can be recommended.

Brown-tail moth, Nygmia phaeorrhoea. The caterpillars feed upon oak and several other native trees. See Pear.

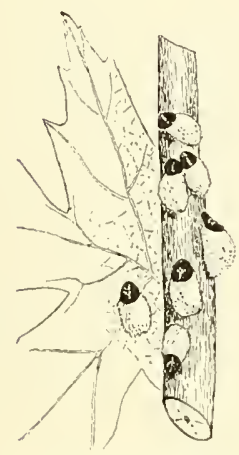

Figure 52.

Cottony maple scale.

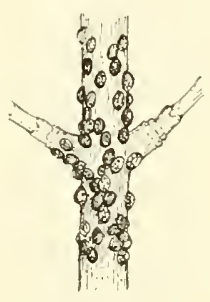

Figure 53. Terrapin scale.

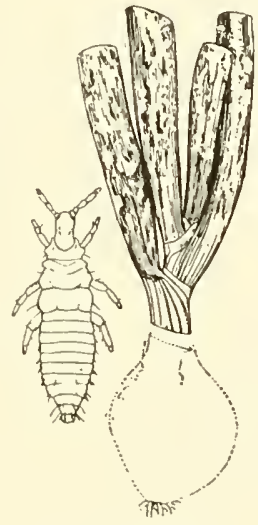

Figure 54 .

Onion thrips.

Canker worms. Canker worms often feed upon oak as well as many other kinds of fruit, shade and woodland trees. See Apple.

Gipsy moth, Porthetria dispar. Oak is one of the preferred food plants for the caterpillars. See Apple.

Leaf miners. There are several leaf miners on oak, one of the most conspicuous being the white blotch leaf miner, Lithocolletis hamadryadella. Other species are L. fitchella and L. tubiferella.

Little is known about control measures.

Leaf mites. Mites often infest oak leaves, causing a rusty brown appearance. Paratetranychus bicolor is perhaps the worst offender but $T$. bimaculatus is often present in abundance.

Mites have been successfully controlled by spraying with glue solution, one pound of glue in 10 gallons of water, or linseed oil emulsion.

Leaf rollers. Several species of leaf rollers occur on oak trees, and in 1930, there were several localities in Connecticut where black, white, red and pin oaks were partially or nearly defoliated. From material collected there were reared two species of small moths, Tortrix albicomana and $T$. quercifoliana, the latter the more common and probably chiefly responsible for the injury.

Spraying with lead arsenate will protect the foliage.

Oak galls. Oak trees are subject to galis and many different species are found upon them. Only a few of the more conspicuous galls can be mentioned here. The large oak apple, Amphibolips confluens, is a globular 
gall from one to two inches in diameter, occurs on black, red and scarlet oaks; the gouty oak gall, Andricus punctatus, appears as rough cylindrical galls surrounding the twigs on black, red and scarlet oak; the oak bullet gall, Disholcaspis globulus, is a smooth spherical gall half an inch in diameter, occurring on white oak; the oak seed gall, Andricus seminator, is a mass varying from a half an inch to nearly two inches in diameter on white oak; and the white oak club gall, Andricus clavula, a woody swelling at the ends of twigs on white oak.

No remedies can be recommended.

Oak gall scale, Kermes sp. Several species of gray or yellow globular scales occur on the twigs of various species of oak, usually in the axils of leaves or buds.

Control has been obtained by a dormant spray with miscible oil, one part in 15 parts of water, applied in early spring.

Orange-striped oak worm, Anisota senatoria. This is a caterpillar striped lengthwise with black and orange, with short black spines on some of the segments, and two longer fleshy protuberances or horns back of the head. It reaches a length of about one and three-fourths inches and feeds on scrub oak and some other species, becoming mature in August. It hibernates as pupae in the soil and the moths emerge during June. There is one annual generation. The adults are a tawny orange color with a pur. plish diagonal line on each wing, and have a wing spread of about one and three-fourths inches.

Spraying with lead arsenate will prevent defoliation.

Pit-making oak scale, Asterolecanium variolosum. This is a green glossy circular scale partly sunken in the bark, that occurs on the English oak and chestnut oak. During the past few years it has become quite abundant on chestnut oak around New Haven. This scale is about onesixteenth of an inch in diameter. It winters in a nearly mature condition and the young appear in May.

A spray of miscible oil, one part in 15 parts of water, in early spring, has been effective in controlling this scale. (Fig. 48.)

Twig pruner, Hypermallus villosus. Small twigs are constantly dropping upon the ground under the oak trees in July and August. Some of them hang with dried leaves and they have been cut off by the larva of this beetle. The eggs are laid in July on the smaller twigs, and the young grubs work for a time, under the bark, then tunnel along the pith in the center of the twig. When nearly full grown the borer cuts off nearly all of the wood and the twig, with the borer inside, breaks off in the wind and falls to the ground. The insect hibernates in the twig and the beetle emerges the following summer. It is grayish brown with body about fiveeighths of an inch in length with long slender antennae.

The fallen twigs should be gathered and burned.

Two-lined chestnut borer, Agrilus bilineatus. This borer commonly infests oak. See Chestnut.

Walkingstick, Diapheromera femorata. Oak trees are occasionally partially stripped in September by green and brown stick-like insects called walkingsticks. Such an outbreak occurred in Voluntown, Conn., in 1930, where more than 30 acres of woodland were affected, the defoliation varying from 15 to 80 per cent. Walkingsticks belong to the Orthoptera and are related to the grasshoppers. They feed chiefly on oak and there is one generation each season.

Trees may be protected by a spray of lead arsenate.

Oats

Aphids. Several species of grain and grass aphids are known to infest oats, such as Macrosiphum granarium, Rhopalosiphum prunifoliae and Toxoptera graminum on the stems and leaves and Anuraphis maidi-radicis, 
Geoica squamosa and Forda olivacea on the roots. All except the last are known to occur in Connecticut.

In case of a severe infestation of the leaf forms, the crop should be cut for hay.

Armyworm, Cirphis unipuncta. The armyworm occasionally becomes very abundant and devours grass, corn, oats and other kinds of grain. See Grass.

European corn borer, Pyrausta nubilalis. Although this insect prefers corn, it sometimes infests the larger stems of oats and other grains. See Corn.

\section{Okra}

Aphids. The spinach aphid, Myzus persicae, sometimes infests okra. Infested plants should be sprayed with nicotine sulfate and soap.

Corn ear worm, Heliothis obsoleta. The corn ear worm occasionally feeds upon okra. See Corn.

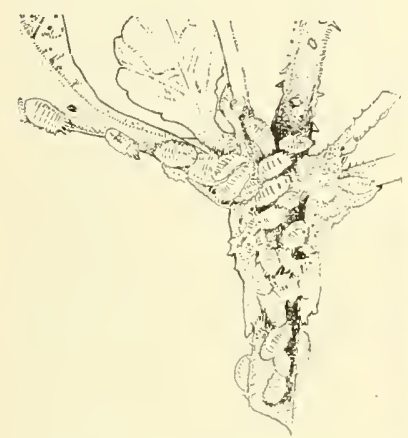

Figure 55. Mealybug.

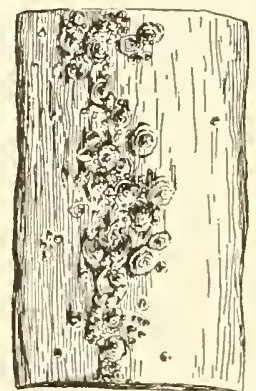

Figure 56.

San José scale.

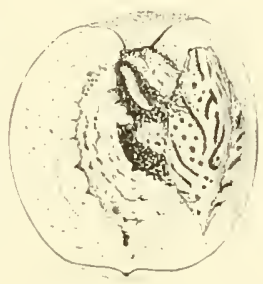

Figure 57.

Oriental fruit moth.

\section{Oleander}

Mealybugs, Pseudococcus citri and $P$. adonidum. These mealybugs commonly infest oleander. See Lantana.

Soft scale, Coccus hesperidum. This scale infests oleander and many other greenhouse plants. See Fern.

White or oleander scale, Aspidiotus hederae. This is a flat, nearly circular, dirty white or light gray scale that is common on the leaves of oleander and many other greenhouse plants.

It can be controlled by fumigating the greenhouse with cyanide gas or by repeated sprayings with nicotine and soap or with pyrethrum-soap.

\section{Onion}

Garden springtail, Sminthurus hortensis. This little springtail often devours the young seedling onions. See Beet.

Lesser bulb fly, Eumerus strigatus. This insect also injures onion. See Narcissus.

Onion maggot, Hylemyia antiqua. Onion plants are often severely injured by small white maggots that feed in the lower part of the stem or 
bulb. The flies appear in the fields in spring and lay eggs in the base of the leaf sheath near the ground. The young maggots work their way downward into the stem where they feed. Infested young plants may die outright, but in older plants the maggots burrow into the bulb and decay follows. Several maggots may infest a single bulb. There are two or three broods annually and the insect hibernates both as adult, and in the pupa stage in the soil.

One of the most satisfactory control measures is to spray the tops with a Bordeaux-oil emulsion made by mixing $1 \frac{1}{2}$ gallons of lubricating oil stock emulsion with a 4-6-50 Bordeaux, or a sweetened poison when the flies first appear in order to kill them before they lay their eggs. The following materials may be used: Sodium arsenate, $1 / 5$ ounce; water, 1 gallon; molasses, 1 pint. The application should be repeated at weekly intervals or oftener in rainy periods.

Onion thrips, Thrips tabaci. Thrips injury is called "white blast" because the seriously injured plants turn white due to the devouring of the outer tissue containing chlorophyll. Thrips are very small insects with narrow fringed wings that are lacking in the nymphs. In feeding a thrips leaves a whitish chain-like mark on the surface.

The insects hide in the sheaths of the leaves and are difficult to reach by a spray, though some of them can be killed by a spray of nicotine sulfate. All tops and trash and the grass surrounding the field should be burned to kill the over-wintering insects. (Fig. 54.)

\section{Pachysandra}

Euonymus scale, Chionaspis euonymi. Pachysandra is often severely infested by this scale. See Euonymus.

San José scale, Aspidiotus perniciosus. Occasionally this scale infests Pachysandra. See Pear.

\section{Palms}

Scale insects. Many kinds of scale insects infest the different species and varieties of palms in greenhouses and dwellings. Some of the more important of them are as follows: Mealybugs, Pseudococcus sp.; hemispherical scale, Saissetia hemisphaerica; soft scale, Coccus hesperidum; circular scale, Chrysomphalus aonidum; Morgan's scale, Chrysomphalus dictvospermi; thread scale, Ischnaspis longirostris; and Fiorinia fioriniae.

They can all be controlled by cyanide fumigation, and by repeated spraying with nicotine sulfate and soap or with pyrethrum-soap.

\section{Pansy}

Cutworms. Certain kinds of cutworms occasionally feed upon the leaves and flowers of pansy plants in greenhouses and coldframes. In one case in New Haven in the spring of 1922 , considerable injury was caused by small cutworms that fed at night and during the day were coiled up in the soil around the plants. From the larvae there were reared in September, some adult moths having a wing spread of one and one-half inches, which were identified as Feltia venerabilis.

The plants were finally sprayed with lead arsenate and the injury ceased. Garden slugs. Pansy plants are often injured by garden slugs. See Lettuce.

Greenhouse or celery leaf tier, Phlyctaenia rubigalis. This insect is on record as having caused severe injury to pansy under glass. See Celery. 


\section{Parsley}

Celery worm, Papilio polyxenes. This caterpillar feeds upon parsley. See Celery.

Parsley stalk weevil, Listronotus latiusculus. Parsley is sometimes injured by the larvae of this weevil, which hollows out the main stem.

Remedies are unknown.

\section{Parsnip}

Aphids. The bean aphid, Aphis rumicis, the spinach aphid, Myzus persicae, and the potato aphid, Macrosiphum solanifolii, Aphis saliceti and Siphocoryne xylostei, all occasionally infest parsnip.

Usually treatment is unnecessary but if severe injury seems probable, dusting heavily on a warm day with nicotine dust is advisable.

Carrot rust fly, Psila rosae. This insect injures the roots of parsnip. See Carrot.

Celery worm, Papilio polyxenes. The celery caterpillar often feeds upon parsnip. See Celery.

Parsnip leaf miner, Acidia fratria. Parsnip leaves are sometimes mined by the larvae of this insect in May, June and July. The larvae are greenish, about one-fourth of an inch in length when full grown, and they form blotch mines that are most abundant on the lower leaves. They pupate within the mines and in two weeks there emerges a pale yellow fly with green abdomen and brown curved bands on the wings.

Little is known of the life history of this insect or of any measures of control.

Parsnip webworm, Depressaria heracliana. When parsnip and celery are grown for seed, much injury is caused by this caterpillar which webs together and feeds upon the unfolding blossom heads. The caterpillar is slightly more than half an inch long when full grown, greenish yellow with black head and legs, and covered with small black warts. There is one annual generation and the moths live through the winter. When nearly mature, the caterpillars leave the web and burrow inside the flower stems where they pupate.

Infested seed fields may be dusted or sprayed with lead arsenate.

\section{Pea}

Green clover worm, Plathypena scabra. This caterpillar feeds upon pea foliage. See Bean.

Pea aphid, Illinoia pisi. This aphid is the most important pest of the pea crop. It infests the leaves and stems in June, and sucks the sap often causing great injury. Once severely infested, even if the aphids are killed, the vines have been stunted so that the crop is a failure and severe losses result. Early peas may mature a crop before the aphids can injure them. This aphid passes the winter on clover and breeds there in spring. During May winged individuals migrate to peas and give birth to living young. The aphid population increases rapidly, as on clover and peas there are as many as 13 generations in a season.

Perhaps the best treatment is to apply a nicotine dust on a warm day before the plants have been severely injured.

Pea weevil, Bruchus pisorum. The adult of this insect is a brownish beetle, spotted with gray, dark brown and white, and measuring about one-fifth of an inch in length. These beetles appear in the field about the time the peas are in blossom, and after light feeding on the foliage, the females lay their eggs on the surface of the newly-formed pods. In about 12 days the eggs hatch and the young larvae or grubs drill into the pods 
and work their way into the peas where they feed until fully grown. They pupate, and often remain in the seeds until the following spring. There is only one generation each year, and this weevil does not breed in the dried seeds as does the bean weevil.

The weevils in the seeds may be killed by fumigating in a tight box for 36 hours at a temperature of $70^{\circ} \mathrm{F}$., or higher, using one pound of carbon disulfide for each 100 cubic feet. In small quantities, peas may be heated to a temperature between 120 and $130^{\circ} \mathrm{F}$. for five or six hours, and the weevils will be killed.

Potato aphid, Macrosiphum solanifolii. This aphid often infests peas with the pea aphid and should be treated in the same manner. See Potato.

\section{Peach}

Aphids. Several species of aphids occur on peach trees. Some of the more important ones are as follows: the black peach aphid, Aphis persicaeniger, lives through the winter on the roots, and migrates to the leaves and tender shoots in spring; the black cherry aphid, Myzus cerasi; the spinach aphid, also called the green peach aphid, Myzus persicae; and the rusty plum aphid, Hysteroneura setariae.

The common treatment is to spray with nicotine and soap or dust with nicotine dust.

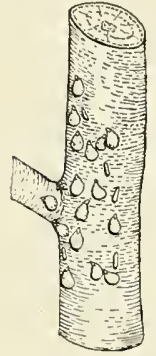

Figure 58.

Scurfy scale.

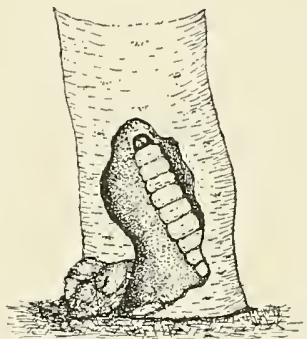

Figure 59.

Peach borer.

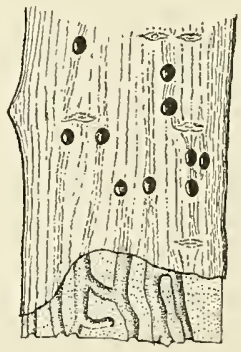

Figure 60.

Work of fruit bark beetle.

Fruit bark beetle or shot-hole borer, Scolytus rugulosus. This little dark brown beetle breeds under the bark of fruit trees including peach, and emerges through small circular holes resembling shot holes. The larval galleries nearly or quite girdle the stem or branch, and on stone fruits gum exudes from the exit holes. The adult beetle is about one-tenth of an inch in length, is dark brown and emerges in early spring. There are probably two generations each year in the northern states, and this pest generally breeds in injured or weakened trees. Consequently, it is advisable to keep the trees as vigorous as possible. In general, good protection against this insect is afforded by a dormant spray of lime-sulfur. (Fig. 60.)

Oriental fruit moth, Grapholitha molesta. This is the most destructive insect pest of peach and quince in Connecticut. The larvae tunnel in the tender shoots of peach early in the season, and later leave the twigs and enter the fruit. Those hatching late in the season go directly into the fruit. This insect is the cause of most of the wormy peaches, and there are three broods and sometimes a partial fourth brood in Connecticut. The mature larva is pink and about half an inch in length. As a twig borer, it kills the tip and causes the shoot to branch. The insect hibernates as a mature 
larva in an impervious silk case on the bark of the trunk or upon rubbish. It pupates in the case and the moth that emerges has a wing spread of half an inch or less, and is gray in color with chocolate brown markings. The females lay eggs upon the under sides of the leaves and, in some cases, on the twigs.

Injury is worse on trees that have made a rank growth and this condition should be avoided as much as possible. Orchard and packing house sanitation should be practiced.

Sprays are not effective in the control of this insect. Trichogramma egg-parasites and Ichneumon larval parasites are now being reared artificially for the control of the Oriental fruit moth. (Fig. 57.) For further information, consult Bulletin 313 of this Station.

Peach borer, Aegeria exitiosa. This is one of the major insect pests of peach and is exceeded in importance only by the Oriental fruit moth. The larvae tunnel in the wood just beneath the bark on the trunks of the trees. Masses of semi-transparent peach gum exude from the wound and the borer, especially when mature and nearly ready for pupation, often occurs in the mass of gum. The empty pupa case often protrudes from the mass of gum after the emergence of the adult moth. The moths emerge in July and August and are wasp-like clear-wings with a wing spread of about one inch. The mature larva is about an inch long and light yellow in color with dark brown head. There is one generation annually.

Various control measures have been devised, which include digging out the borers, applying repellent washes to the trunks, and wrapping the trunks with paper, wire netting and other materials. Peach trees should be examined twice each year and the borers removed; once early in June and again late in September. Some orchardists use paradichlorobenzene, one ounce to the tree, distributed on the ground in the form of a circle surrounding the trunk and a few inches away from it, and cover the material with soil mounded up around the trunk. This mound should remain for about six weeks and usually all borers are killed below the top of the mound. This treatment gives its greatest degree of effectiveness if practiced in autumn. It is liable to injure young trees, but trees four years old or older are not injured. (Fig. 59.)

Peach sawfly, Pamphilius persicus. Occasionally peach leaves are devoured in June and July by pale bluish green larvae, five-eighths of an inch in length. When mature they go into the ground and at a depth of three to six inches make oval earthen cells in which they pass the winter. The following spring they pupate, and the adults emerge in late May and early June. They are black with yellow markings.

Spraying or dusting with lead arsenate is the remedy.

Peach twig borer, Anarsia lineatella. The larva of this insect is a borer in the twigs and also occasionally enters the fruit, but it can be distinguished from that of the Oriental fruit moth by its reddish brown color. The larva is less than half an inch long when mature and constructs a loose cocoon under the curled edge of the bark. Ten to 12 days later the steel gray moth emerges. It has a wing spread of about half an inch. There are four broods each season. The presence of the larva in the twig is indicated by the reddish brown masses of chewed bark webbed together in the crotch.

The usual dormant spray of lime-sulfur or miscible oil seems to give a satisfactory control of this insect.

Plum curculio, Conotrachelus nenuphar. The plum curculio is an important peach pest. See Plum.

San José scale, Aspidiotus perniciosus. This scale often infests peach trees and has caused severe injury. See Pear.

Tarnished plant bug. Lygus pratensis. This bug mentioned under apple and in many other places in this bulletin, causes a different type of 
injury on young peach trees than on most other plants from the fact that when the bug punctures the growing tip, the tip often dies and turns brown. It resembles the injury of the Oriental fruit moth, except that the shoot is not bored or hollowed out. Other species of Lygus also injure the fruit in a manner known as cat-facing.

There are no specific measures to prevent injury by the tarnished plant bug, but it may be reduced somewhat by keeping the field and surround. ings free from weeds.

White peach scale, or West Indian peach scale, Aulacaspis pentagona. This is not a pest of peach orchards in Connecticut, although it has occasionally been found on peach trees in gardens along the coast. The female has a circular scale about one-tenth of an inch in diameter, light gray or dirty white, with yellow or brownish nearly central exuvium, and the male has an elongated scale, pure white, and is usually clustered at the base of a branch. This scale also infests privet, lilac, catalpa, flowering peach and flowering cherry.

This scale is easily killed by a dormant application of lime-sulfur or miscible oil.

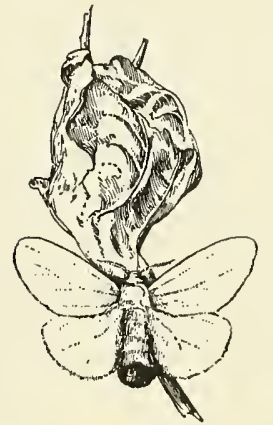

Figure 61. Brown-tail moth.

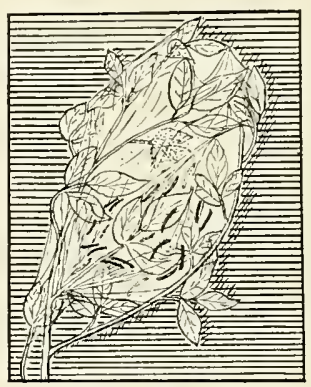

FigURE 62

Nest of fall webworm.

Pear

Aphids. The green apple aphid, Aphis pomi, occasionally infests pear. See Apple.

Brown-tail moth, Nygmia phaeorrhoea. The insect in 1915 had spread over the eastern half of Connecticut, but has since largely disappeared. The female moth lays reddish brown egg-masses in July on the under side of leaves. The eggs hatch in from two to three weeks and the young caterpillars feed in colonies on the most tender terminal leaves, webbing them together and fastening them securely to the twig to make a nest two or three inches long. In this nest the caterpillars spend the winter and in the spring resume feeding, becoming full grown late in June. They are then about one and one-half inches long, reddish brown with white markings as follows: beginning with the fourth, each segment bears a pair of white tufts, one on each side. The ninth and tenth segments each bear a small coral red tubercle covered with poisonous hairs, which cause an intense itching and rash on the human skin. The moth is pure white except for a tuft of brown hairs at the tip of the abdomen, and has a wing spread of about one and one-half inches.

Control measures consist of clipping off and burning the nests in winter, and spraying the foliage in May with lead arsenate. (Fig. 61.) See Bulletin 182 of this Station. 
Cherry or pear slug, Eriocampoides limacina. This insect often defoliates young pear trees. See Cherry.

Codling moth, Carpocapsa pomonella. The codling moth also injures the fruit of pear. See Apple.

Fall webworm, Hyphantria cunea. White webs or nests on the ends of the branches of fruit, shade and woodland trees the latter half of summer are formed by this insect. There is one complete annual generation and a partial second in Connecticut. The eggs are laid in white masses containing 400 to 500 eggs, on the under side of the leaves. They hatch in 10 days and the larvae from each egg-mass live together as a colony and spin webs enclosing the leaves, usually at the end of a branch, and feed inside the nest. When the food has been exhausted, they extend the nest to include additional foliage. When nearly full grown, they leave the nest and crawl about seeking a place to transform and finally make their gray cocoons on the under side of rubbish, fences, crevices in the bark, and other protected places, where they hibernate. The fully grown caterpillar is about one and one-fourth inches in length with a broad dark brown stripe along the back, and yellowish sides thickly peppered with small blackish dots. Each segment is crossed by a row of tubercles bearing rather long light brown hairs. The moths have a wing spread of about one and onefourth inches, and vary from pure satiny white to white thickly spotted with small dark brown dots.

Control measures consist of cutting off and burning the nests when first formed, and spraying the trees with lead arsenate. (Fig. 62.)

False tarnished plant bug. Lygus invitus. This bug causes serious injury in pear orchards by puncturing the growing fruit, which becomes knotty, deformed and gritty in texture. The adult resembles the tarnished plant bug though a trifle smaller and paler. The winter is passed by the egg stage in the bark, and the eggs hatch at blossoming time. The nymphs pass through five immature stages and after the first are conspicuously green, and begin to puncture the fruit as soon as it sets. They become mature about the middle of June.

Control measures consist of the use of nicotine sulfate in sprays applied immediately after the blossoms fall, and repeated a week later.

Leaf blister mite, Eriophyes pyri. The unfolding leaves of pear and apple are often disfigured by greenish yellow or reddish blisters that later turn brown. In severe cases the leaves may drop in mid-summer. There are colonies of microscopic mites living within the tissues of the leaf. They pass the winter beneath the bud scales.

Perhaps the simplest form of control is to apply a dormant spray of lime-sulfur or miscible oil just before the buds open in spring.

New York weevil, Ithycerus noveboracensis. The adult beetles sometimes cause severe injury to young pear trees by eating off the leaf buds in early spring. They may also eat the bark of the new growth, and cut off the leaf stalks and new shoots. They feed chiefly at night. This beetle is ash-gray in color with darker spots, and is about five-eighths of an inch in length. The only known means of control is by hand picking and by jarring the insects onto sheets placed under the trees.

Pear midge, Contarinia pyrivora. In June the small pears often drop in great numbers, and some of them are split open. When examined they are found to be infested with maggots. A small midge resembling a mosquito lays eggs in the blossoms and on hatching the maggots work their way down into the core and gradually hollow out a large cavity that may occupy the entire interior of the young fruit. The maggots reach maturity in June; the fruit usually cracks open and falls to the ground; and the larvae enter the soil, where they pupate and hibernate.

Applications of nicotine sulfate or other similar contact sprays when the buds show pink will kill the adults. 
Pear psylla, Psyllia pyricola. This is one of the more serious pests of pear, and there are at least four broods each season. The adults hibernate under the edges of the rough bark of the trunk and branches, emerge during the first warm days in April, and soon deposit eggs in old leaf scars, in cracks and crevices, and around the base of the terminal buds. Most of these eggs are laid before the buds open, and nearly all have hatched by the time the petals fall. The nymphs go to the axils of the leaf-petioles
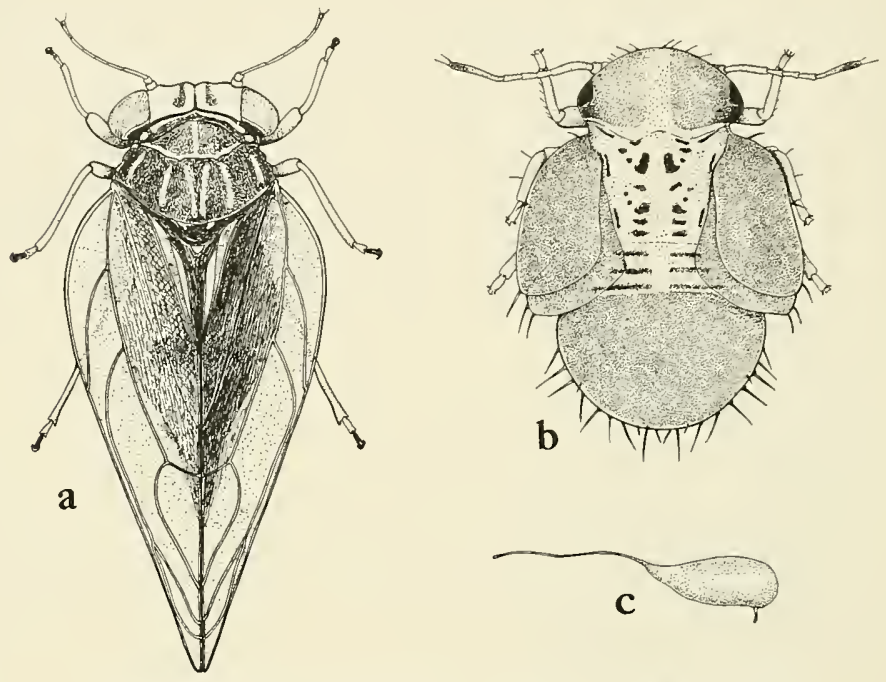

Figure 63. Pear psylla. a. adult, b. nymph, c. egg.

and begin to suck the sap. Much of the sap is excreted as honey-dew which drips upon the lower leaves and in it a sooty fungus grows. About a month is required for the complete life cycle and by midsummer a badly infested tree is blackened throughout on leaves and fruit. Some of the leaves will fall before the fruit ripens. The adult is about one-tenth of an inch long and resembles a tiny cicada.

The usual control consists of a dormant spray of miscible oil or limesulfur just before the eggs are laid. If the dormant spray has not been applied or if a tree becomes blackened from psyllid infestation during the summer, it should be sprayed with nicotine sulfate and soap. (Fig. 63.)

Pear thrips, Taeniothrips inconsequens. The pear thrips causes injury to the blossoms of the pear and some other fruit. The black adults emerge from the ground about April 1, work their way into the swelling buds, and soon lay eggs in the stems and midveins of the unopened bud. The eggs hatch in two weeks and large numbers of the white nymphs feed upon the unfolding buds. Heavily infested orchards appear as if a fire had scorched the trees, and the blossoms are destroyed.

The best treatment is to spray soon after the adults first appear in early spring, using a 2 per cent miscible or lubricating oil with 1 pint of nicotine sulfate added to each 100 gallons of diluted mixture. In heavily infested orchards, this application should be repeated at the cluster-bud stage.

Pears injured by squirrels. Pears are often cut from the trees by squirrels in August. The fruit drops to the ground and though not ripe, 
the squirrels bite into it and eat the seeds. Sometimes the entire crop is ruined in this manner.

Possibly something distasteful to the squirrels, like lime-sulfur or pyrethrum-soap, could be sprayed upon the fruit to protect it, but the efficacy of such a repellent has thus far not been demonstrated. Feeding the squirrels with plenty of nuts or other food at this period will no doubt reduce the injury to pears.

Quince curculio, Conotrachelus crataegi. This insect injures pears in a different manner than it usually works in quince. In pear, a cavity between the skin and the core contains the larva. On the outside there is a flattened hardened area with a puncture in the center but the fruit is not especially knotty or deformed. A spray of lead arsenate should be applied soon after the beetles appear about the first week in July. For life history, see Quince.

San José scale, Aspidiotus perniciosus. This is a small circular dark gray scale that infests the bark of nearly all kinds of fruit trees and many other kinds of trees and shrubs. It hibernates in a half-grown state and there are three broods each season. The largest scales are the females, which are about one-sixteenth of an inch in diameter, and circular with a raised center or nipple. The males are smaller and elongated, with the nipple not in the center. This scale does not produce eggs, but gives birth to living young which crawl about for a few hours then settle upon the bark.

The usual control treatment is to spray the dormant trees in spring with lime-sulfur or miscible oil. Summer sprays containing lime-sulfur or nicotine sulfate will kill many of the young crawlers. (Fig. 56.) See Bulletin 165 of this Station.

Scurfy scale, Chionaspis furfura. This is a whitish or light gray scale that infests pear, apple, currant and some other trees and shrubs. The female is pear-shaped and about one-tenth of an inch in length, and the insect passes the winter in the form of purplish eggs under the parent shell. The male is much smaller, long and narrow, with three longitudinal ridges or carinae. The eggs hatch in Connecticut about the last week of May and the yellow crawlers may be seen on the bark. They soon establish themselves and begin to suck the sap.

A spray of nicotine sulfate and soap early in June will readily destroy the young. Dormant treatments with lime-sulfur or miscible oil are also effective in holding this insect in check. (Fig. 58.)

Sinuate pear borer, Agrilus sinuatus. The grub or larva of this Buprestid beetle tunnels in the branches causing ugly scars and some of them to break off. The adult is a slender glossy bronze-brown beetle one-third of an inch long, and the females lay eggs in the crevices and under the edges of the bark during June. In early July the eggs hatch and the young grubs excavate narrow sinuous tunnels in the sapwood just beneath the bark. They become partly grown when winter arrives, hibernate in the burrows, and continue their destructive work the following season. The galleries are then larger and their course shows through the bark. By the second September the grubs are about one and one-half inches in length and they tunnel deeper into the wood and excavate the pupal chambers which are connected by exit holes with the bark. Here they hibernate and the following April they pupate and the beetles emerge a month later. Two years are required for the complete life cycle.

Severely injured branches should be cut off and burned, and the trees fertilized and kept in a vigorous condition. Spraying the foliage in late May and June will kill some of the beetles that feed upon the leaves. Probably sprays or washes of lime-sulfur and lead arsenate applied to the bark may act in some measure as a deterrent. 


\section{Peony}

Rose chafer, Macrodactylus subspinosus. The beetles feed upon and soil nearly all the white flowers. See Rose.

\section{Pepper}

Aphids. Pepper plants are occasionally infested by at least three different species of aphids, as follows: the melon aphid, Aphis gossypii; the spinach aphid, Myzus persicae; and the potato aphid, Macrosiphum solani. folii.

The remedy is to spray with nicotine sulfate or dust with nicotine dust.

Pepper maggot, Zonosema electa. The maggots of this fly infest the fruits of pepper, causing them to decay. The eggs are deposited in July and August in the wall of the fruit and of ten project into the interior cavity. They hatch in 10 days, and feed inside the core until mature, a period varying from 12 to 22 days. They then make an exit, usually near the stem, and go into the ground and pupate one or two inches beneath the surface. There is one generation each year in New Jersey and apparently the insect hibernates in the pupa stage in the soil. The adult is a twowinged fly, light yellowish brown in color with three brown bands across each wing. talc.

Partial control may be obtained by repeated dusting of the plants with

\section{Petunia}

Greenhouse orthezia, Orthezia insignis. This greenhouse insect often infests bedding plants out-of-doors, including petunia. See Lantana.

Potato flea beetle, Epitrix cucumeris. This tiny black flea beetle feeds upon a great variety of plants, of which one is petunia. See Potato.

Yellow woolly bear, Diacrisia virginica. The yellow hairy caterpillars feed upon petunia and a great many other kinds of plants in the garden. See Verbena.

\section{Phlox}

Phlox bug, Lopidea media. This bug injures phlox by puncturing the tender shoot or leaves at the growing tip and sucking the sap. It appears to be of minor importance in Connecticut.

Should it become abundant the bugs may be killed by spraying with nicotine sulfate and soap.

Red spider, Tetranychus bimaculatus. This is the most serious of all pests of phlox. It infests the under sides of the leaves, which become light yellow in color, and the plants have a generally unthrifty appearance. Sometimes the spiders, their eggs and eggshells more or less enclosed in webs are formed on the upper as well as on the under leaf surface.

Perhaps the best treatment is to spray thoroughly the under sides of the leaves with an oil like "Volck" or some preparation of "Derris" or rotenone.

Stalk borer, Papaipema nitela. This borer occasionally tunnels in the stems of phlox. See Dahlia.

\section{Pine}

Aphids. There are several leaf aphids on the various species of pine. Some of these collected in Connecticut are Dilachnus strobi, and $D$. pinicola. 
Any of these aphids can be controlled by spraying with nicotine sulfate and soap.

European pine shoot moth, Rhyacionia buoliana. This insect is a serious pest of red and Scotch pine and it is known to infest other pines. The larva feeds upon the buds and tunnels in the new shoots, with the result that the terminal buds are killed and lateral shoots become leaders. It also feeds on the outside of the new shoots and this makes them crooked near the tips, a condition called "bayonet growth." The larva hibernates in the buds and pupates in its burrow about June 1 . The moth emerges the latter part of June and has a wing spread of about two-thirds of an inch. The fore-wings are reddish brown crossed by two whitish bands near the tips. The eggs are laid on the twigs near the terminal buds. The larva is brown with black head and reaches a length of about five-eighths of an inch when mature. There is one generation each year.

Some degree of control may be obtained by cutting off and burning the infested tips in late winter, or by spraying three times at weekly intervals, beginning about June 21, with nicotine sulfate, 1 part in 400 parts water, to which is added 1 per cent of the oil known as "Penetrol." (Fig. 65.) See Circular 80 of this Station.

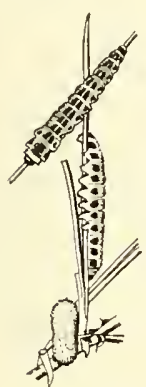

F I G URE 64 . Abbot's pine sawfly.

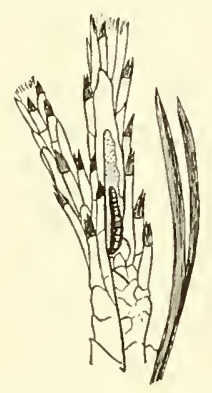

F I G U R E 65. European pine shoot moth.

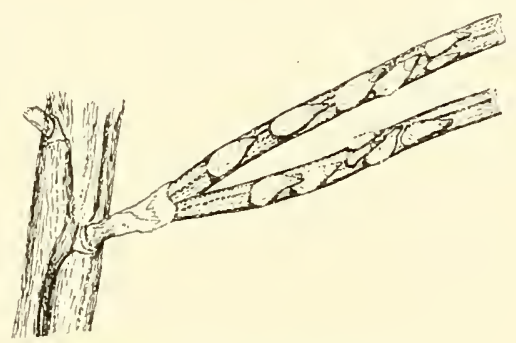

Figure 66. Pine leaf scale.

Pales weevil, Hylobius pales. This weevil or snout beetle has the reputation of gnawing the bark from the trunk and twigs of young seedling pines and from the lower branches of older trees where they are near the ground. There is probably more danger of injury to young trees by this insect if they are planted where pine trees have recently been cut.

It is safer to burn the slash and wait two years before planting young: trees on such land.

Pine bark aphid, Adelges pinicorticis. This is a woolly aphid that infests white pine. Small masses of wax secretion at the base of the leaf clusters contain the eggs which carry the insect through the winter. In summer white flocculent patches appear on the trunks, base, and under sides of the larger branches. These are colonies of brown aphids covered with wax secretion and in some instances are so abundant as to reduce the vitality of the trees. There are several generations each season.

These aphids are readily killed by a spray of nicotine sulfate and soap. (Fig. 67.)

Pine bark beetles. There are several small bark beetles that commonly breed in the living bark of stumps, injured or dying pine trees. Some of the more important species are the black turpentine beetle, Dendroctonus terebrans; the red turpentine beetle, Dendroctonus valens; the coarse writing bark beetle, Ips calligraphus; and the pine bark beetle, Ips pini. 
In severe infestations of these beetles little can be done in the way of control except to cut and peel or burn the infested trees.

Pine leaf scale, Chionaspis pinifoliae. This is a white pear-shaped scale that infests the leaves of various species and varieties of pine, including white, red, Scotch, Austrian and mugho pines growing in sheltered places. There are two generations each season and the insect hibernates in the form of eggs underneath the old shells. The eggs hatch the latter half of May; the young crawl about for a few hours then settle down, begin feeding, and secrete the wax that forms the shells. Early in July the first brood matures and eggs for the second brood are formed under the shells. These hatch later in July and early August and the second brood matures and forms eggs the first half of October.

Perhaps the best treatment is a spray of nicotine sulfate, 1 part in 500 parts of water, with soap, about June 1, and another August 1 to 15 . (Fig. 66.)

Pine pyralids, Tetralopha robustella and T. melanogrammos. Seedlings of red pine and white pine are sometimes infested with caterpillars that web together the leaves and frass, live in tubes within the mass and feed upon the leaves. Some of these frass balls are globular and two inches or less in diameter, others are more elongate. Little is known of the life histories, though the adult of $T$. robustella has been reared from one of these frass balls on white pine.

Spraying with lead arsenate will probably protect the foliage.

Pine sawflies. There are several species of pine-feeding sawflies in Connecticut and the larvae devour the needles, sometimes defoliating the trees. Some of these are as follows: The introduced pine sawfly, Diprion simile, has brown and green striped and mottled larvae; Abbot's sawfly, Neodiprion pinetum, has whitish larvae with black spots and black head, that feed upon the white pine; the red-headed pine sawfly, Neodiprion lecontei, has yellow larvae with black spots and red head, that feed upon white, red, and mugho pines; another species, $N$. pinus-rigidae, feeds upon the pitch pine; a larger species, Itycorsia zappei, webs together the needles and its frass to make a nest in which it lives and feeds on Austrian pine.

In case of injury by any of these sawflies, spraying the leaves with lead arsenate will prevent defoliation. (Fig. 64.)

Pine spittle bug, Aphrophora parallela. The immature stages of this insect develop in a froth mass or "spittle ball" on the twigs of different species of pine. These froth masses are from one-half to three-fourths of an inch in diameter and are usually near the tips of the twigs. The adult is gray-brown about one-half an inch long. Little is known about prevention or control.

Pine tube moth, Eulia pinatubana. The larva of this moth webs the pine needles together to form a tube or case in which it lives and devours the terminal third of the leaves. The larva is pale green with light brown head, and is about one-third of an inch in length. The moth has a wing spread of slightly more than half an inch, and the fore-wings are rust-red crossed by two oblique parallel paler bands. The tube usually contains about 15 needles fastened together with silk threads. There is probably one brood each year.

Though not of great economic importance, if it should become abundant, a spray of lead arsenate will control it.

White grubs, Phyllophaga sp. In forest nurseries the roots of pine seedlings and transplants are sometimes eaten by white grubs. See Grass.

White pine weevil. Pissodes strobi. This is the insect that kills the leaders of white pine, and is perhaps the most serious insect pest of white pine at the present time. The adult beetles hibernate under dead bark, stones, and wherever they may find protection in woodland areas, and appear on the trees in April. During May they lay eggs in punctures in 
the bark of the leaders and the grubs feed under the bark, often girdling them so they wilt and die in July. The grubs are then mature and make cells in the wood of the leader and pupate therein. The beetles begin to emerge the latter part of July and continue into September. They go early into winter quarters. There is one generation each year. The adult is a reddish brown beetle with white spots, and about one-fourth of an inch or slightly more in length. Seedlings planted in shade are seldom injured, but those in sunny situations are infested.

Jarring the trees twice a week from May 1 to June 15 and catching the beetles in a net is one method of control. Ornamental plantings may be treated by spraying the leaders about the first of May, and some benefit follows applications of lead arsenate, lime-sulfur, which perhaps act as repellents. In forest plantations the practice of cutting and burning the weeviled leaders during the first half of July has given fairly satisfactory results.

\section{Plum}

Aphids. There are several species of aphids that sometimes infest plum trees. Some of these are the green apple aphid, Aphis pomi; the spinach aphid, Myzus persicae; the mealy plum aphid, Hyalopterus arundinis; the rusty plum aphid, Hysteroneura setariae.

Outbreaks of these aphids on plum can be controlled by spraying thoroughly with nicotine sulfate and soap.

European fruit lecanium, Lecanium corni. This is a very convex, reddish brown soft scale that infests nearly all kinds of fruit, shade and forest trees and shrubs. The scales are not much more than one-eighth inch in diameter, and are often close together on the twigs. They live through the winter in a partially grown condition and the young or crawlers appear in June. There is one generation each year. This insect may be controlled by a dormant spray of miscible oil. (Fig. 69.)

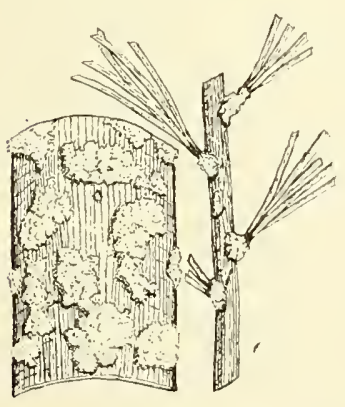

FIGURE 67.

Pine bark aphid.

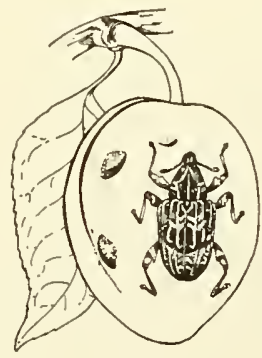

FIGURE 68. Plum curculio.

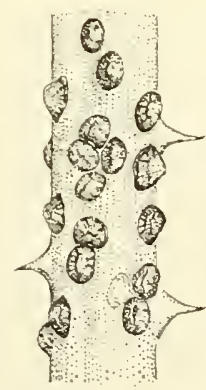

Figure 69. European fruit lecanium.

Fruit bark beetle, Scolytus rugulosus. This bark beetle is sometimes found in plum and other fruit trees. See Peach.

Peach borer, Aegeria exitiosa. The peach borer sometimes infests plum trees. See Peach.

Plum curculio, Conotrachelus nenuphar. This beetle hibernates in woodlands and appears in the orchards about the time the trees blossom. It feeds to some extent upon the petals and upon the fruit as soon as it reaches a size of one-fourth of an inch in diameter. It cuts crescent-shaped 
marks in the fruit and lays an egg under the flap. The grubs hatching from the eggs live and grow in the pulp of the fruit which usually drops to the ground and soon decays. The grubs find their way into the ground and pupate and a month later the beetles emerge, feed for a time on the fruit, and go early into winter quarters. The adult is a brown snout beetle about one-fourth of an inch in length, mottled with gray, and with four humps on its back. There is one generation each year. This insect causes a different type of injury on apple. See Apple.

Jarring the trees each morning for six weeks after they blossom, and catching the beetles on sheets, and spraying the trees each week during the same period with lead arsenate, are the usual control measures. (Fig. 68.). Bulletin 301 of this Station gives further information about this insect.

San José scale, Aspidiotus perniciosus. The San José scale infests plum, especially Japanese plum. See Pear.

\section{Poplar}

Aphids. Several species of aphids occur on poplar. Some of these are as follows: Chaitophorus viminalis, Neothomasia populicola, Aphis davisi, Melanoxantherium populifoliae, $M$. medium and $M$. smithiae. The following aphids form galls on poplar: Thecabius gravicornis, $T$. populiconduplifolius, Mordwilkoja vagabundus and Pemphigus populicaulis.

All aphids except possibly the gall-forming species can be controlled by spraying with nicotine sulfate and soap.

Gipsy moth, Porthetria dispar. Gipsy moth caterpillars commonly feed upon poplar. See Apple.

Oyster-shell scale, Lepidosaphes ulmi. Poplar is very susceptible to infestation by the oyster-shell scale. See Apple.

Poplar borer, Saperda calcarata. The larva of this long-horned beetle is a borer in the trunk and branches of poplar, and causes blackened and swollen scars. The eggs are laid in slits in the bark during July and August and the young borers at first tunnel in the inner bark and sapwood, but later work deeper in the wood and make larger burrows. They hibernate in galleries and it is believed that three years are required to complete the life cycle. The full grown grub is about two inches in length. The beetle is about one and one-fourth inches long and is ash gray with yellow spots.

The only control measures are digging out the grubs or injecting carbon disulfide or nicotine sulfate into the burrows to kill them.

Poplar and willow curculio, Cryptorhynchus lapathi. This beetle infests and destroys all of the larger pussy willows and also infests the smaller stems and branches of Carolina poplar and probably other species. The adults emerge in midsummer and lay eggs in punctures in the bark. The mature grub is about half an inch in length, white and without legs. The adult is about one-third of an inch long, black with the distal third of the wing-covers white.

Badly infested trees or parts thereof should be cut and burned before the beetles emerge. (Fig. 71.)

Poplar leaf beetle, Lina scripta. This is a yellowish beetle marked on the wing-covers with black stripes or spots of variable size, and a trifle more than one-fourth of an inch in length. The beetles appear in early spring and feed on the tender shoots. The females lay yellowish eggs in clusters on the under leaf surface, and the black grubs skeletonize the under sides of the leaves. There are probably three or four broods each season and the insect hibernates as an adult. Another species, Lina lapponica, is smaller, more reddish with black spots, and in certain seasons is just as abundant and injurious as $L$. scripta. 
Both beetles feed upon poplar and willow and may be controlled by spraying with lead arsenate.

Poplar leafhopper, Idiocerus scurra. Occasionally this leafhopper is exceedingly abundant on poplar and must cause some injury as all the insects suck the sap.

In case treatment seems necessary the trees should be sprayed thoroughly and heavily with pyrethrum-soap or with nicotine sulfate and soap, while the nymphs are feeding on the under side of the leaves.

Poplar sawfly, Trichiocampus viminalis. The larvae of this sawfly feed together side by side on poplar leaves, often stripping the trees. The larva reaches a length of two-thirds of an inch and is orange-yellow with

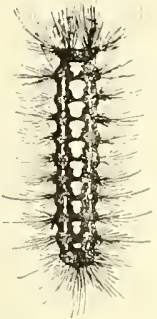

Figure 70. Satin moth caterpillar.

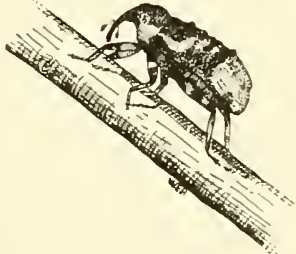

Figure 71. Poplar and willow curculio.

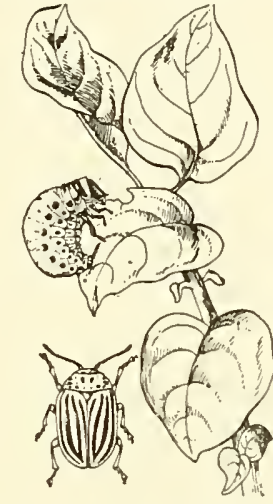

Figure 72.

Colorado potato beetle.

two dorsal rows of large black spots, with a row of smaller spots on each side, and a black head. There are two annual generations, the first brood larvae appearing in June and the second in August. In severe infestations the trees should be sprayed with lead arsenate.

Poplar tent-maker, Melalopha inclusa. Caterpillars of this insect are present in May and June and again in August and September, indicating that there are two broods each season. They make small nests or tents near the tips of the twigs. The mature caterpillar is about one and onehalf inches in length, color dark brown, striped lengthwise with narrow yellow lines, and black head. On each of the fourth and eleventh segments there is a pair of pointed tubercles. The adult moth has a wing spread of one and one-fourth inches, and is brownish gray with apical third of forewings darkened with reddish brown and marked with fine white lines.

This insect seldom defoliates trees but when it is abundant the trees should be sprayed with lead arsenate.

Satin moth, Stilpnotia salicis. The caterpillars of the satin moth feed upon poplar and willow. There is one generation each year and the moths emerge in July and the females lay on the bark masses of eggs that hatch in about two weeks. The young caterpillars feed upon the leaves and on reaching the third stage when they are about one-fourth of an inch in length, they make hibernating cases or pockets in the crevices of the bark. Here they pass the winter and their cases are extremely difficult of detection. In spring the larvae emerge from their cases and feed upon the expanding foliage, often stripping the trees. They reach maturity about July 1 and spin loose cocoons fastened to the leaves in rubbish, crevices of 
the bark, or on the sides of buildings. In nine days the moths appear. The caterpillars reach a length of about one and one-half inches, body blackish with finely reticulated white markings, and two narrow broken subdorsal white stripes between which is a row of large white spots or blotches varying from square to dumb-bell-like in shape. The tubercles are reddish brown and bear yellowish brown hairs. The head is black. The moths are satiny white and have a wing spread of from one and one-half to two inches, the females being the larger. The moths are attracted to lights and during the time of their emergence in July electric light poles and nearby trees are often covered with them.

Spraying the foliage with lead arsenate will prevent defoliation and applications in alternate years will control this pest. (Fig. 70.)

Spiny elm caterpillar, Euvanessa antiopa. Clusters of spiny elm caterpillars commonly feed on poplar and willow. See Elm.

Tussock moths. Caterpillars of the white-marked tussock moth, Hemerocampa leucostigma (see Linden), II. definita, Halisidota maculata and $H$. tessellaris, also feed upon poplar. See Hickory.

\section{Poppy}

Aphids. The bean aphid, Aphis rumicis, commonly infests poppy and the spinach aphid, Myzus persicae, occurs upon it. See Bean.

\section{Potato}

Blister beetles. Several species of blister beetles often feed upon potato. The lead arsenate treatment usually applied to potato is the best control. See Aster.

Colorado potato beetle, Leptinotarsa decemlineata. Both larvae and adults feed upon the leaves, and there are two annual generations. The insects hibernate as adults under rubbish or in the soil, and they emerge and feed upon the first potato shoots to appear. Later, the females lay clusters of yellow eggs on the under sides of the leaves. These eggs hatch in from four to nine days, and the larvae or grubs begin at once to devour the leaves. They pass through three or four stages of larval development in from 10 days to three weeks and in all of them the grubs are strongly convex and dark red with a black head and two rows of black spots on each side. In the last larval stage the red is somewhat lighter in color, and the grub is half an inch or slightly more in length. They go several inches deep into the ground and pupate in earthen cells and from 5 to 10 days later the adults emerge. The beetle is strongly convex, yellow with longitudinal black stripes, and is about three-eighths of an inch in length. Each wingcover has five stripes, and the thorax has two somewhat diamond-shaped black spots in the center and from four to six small spots on either side.

The accepted measure of control is to spray or dust the foliage with lead arsenate or calcium arsenate. (Fig. 72.)

Four-lined plant bug, Poecilocapsus lineatus. This bug often injures potato. See Currant.

Potato aphid, Macrosiphum solanifolii. This aphid often called the pink and green aphid, passes the winter in the form of glossy oval black eggs on rose bushes. The eggs hatch when the leaf buds first unfold and the aphids live for two or three generations on rose, then migrate to potato and other herbaceous plants. The infestation usually becomes noticeable in Connecticut in July when the aphids are sufficient to cause curling of the leaves and are seen on the stems. In severe cases the tips and even the entire stalks die.

Sometimes a heavy driving shower will wash off most of the aphids and seems to be more effective than any artificial treatment. The spinach 
aphid, Myzus persicae, also infests potato. The usual treatment consists in dusting with nicotine dust or under-spraying with nicotine sulfate and soap. (Fig. 74.)

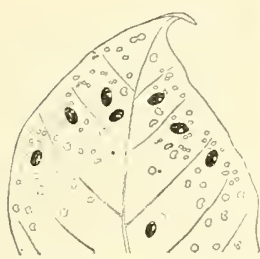

FIGURE 73.

Potato flea beetle.

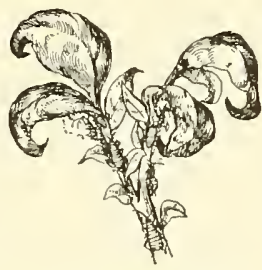

Figure 74. Potato aphid.

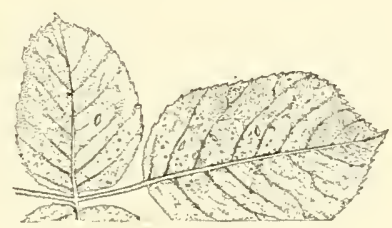

FigURE 75. Rose leafhopper.

Potato flea beetle, Epitrix cucumeris. This is a small black jumping flea beetle that feeds upon the leaves of potato, tomato, tobacco, and many other plants, eating out small round holes from the under side, but leaving the upper epidermis. The remaining tissue soon dies, however, and falls away leaving holes through the leaves which turn yellow and later turn brown and die. This beetle is not much more than one-sixteenth of an inch in length. It lives through the winter under rubbish and in other sheltered places, and may first be found in the spring on plantain and other weeds and sometimes on the leaves of apple, wild cherry and maple. As soon as the preferred food such as potato and tomato plants appear in the garden or field, the flea beetles gather upon them for a feast. There are two broods each season. The over-wintering beetles lay eggs in the soil in June for the first brood. The larvae feed upon tubers and roots of the host plants, potato tubers sometimes being so thoroughly drilled by the larvae as to be worthless. An abnormal growth sometimes takes place around each injury causing scurfy and pimply potatoes. The larvae transform and their beetles emerge early in July. Some of these beetles lay eggs for the second brood of larvae, but others hibernate. There is probably only a partial second brood, though the life history needs to be restudied in Connecticut.

The most severe injury occurs within two or three weeks after the plants come up or are set in the ground. Consequently, plants that are transplanted such as tomato and tobacco, before setting, may be dipped into a mixture of lead arsenate or calcium arsenate with a very little miscible oil or caseinate of lime as a spreader. Such plants will not be injured by flea beetles. Spraying the under side of the leaves of the plants with these materials after setting is much more difficult, but it can be done. In the small home garden where one does not like to use arsenical poisons, the flea beetles on tomato for instance can be controlled with nicotine sulfate and soap. (Fig. 73.)

Potato or bean leafhopper, Empoasca fabae. This leafhopper is responsible for the tip burn or "hopper burn" of potato.

The remedy is spraying with nicotine sulfate and soap. See Bean.

Potato stalk weevil, Trichobaris trinotata. This snout beetle is bluish gray with black head, and is about one-fifth of an inch in length. It emerges in spring, feeds for a time on the potato stems, then deposits eggs singly in the stalk. The eggs hatch in a few days, and the larva tunnels in the pith, usually hollowing out the stalk for a distance of several inches. The stalk wilts, the leaves die, and the grub, when fully grown, eats an exit to the outer skin or bark, then pupates in the burrow. Some of the adults emerge about August 1, bui many of them do not emerge until the following spring. There is one brood each year. 
This insect is best controlled by gathering and burning all vines and solanaceous weeds.

Stalk borer, Papaipema nitela. The stalk borer often tunnels in potato stalks. See Dahlia.

Three-lined potato beetle, Lema trilineata. This is a reddish yellow beetle, about one-fourth of an inch long, with three black stripes running lengthwise on the wing-covers. Probably this beetle hibernates as an adult and there are said to be two annual generations. The beetles appear when potato and tomato plants are growing in the field and lay their small clusters of yellow eggs on the under sides of the leaves. The yellow larvae feed side by side and move backward from the leaf margin as they devour the leaf tissue. They have the habit of carrying a coating of brown excrement on their backs. The beetles become full grown in about two weeks when they are about one-third of an inch long and enter the ground to pupate.

This pest is controlled by the arsenical sprays and dusts used for the control of the Colorado potato beetle.

Tortoise beetles. Like sweet potato and morning glory the common potato is sometimes eaten by tortoise beetles, especially Metriona bicolor, Chiridia guttata and Deloyala clavata. The usual treatment with arsenical poison will control these tortoise beetles. See Sweet potato.

White grubs, Phyllophaga sp. White grubs sometimes cause severe injury by eating into the tubers, especially on sod land. In such cases the crop should be harvested as soon as mature. See Grass.

Wireworms. Family Elateridae. Not only do the wireworms injure the stems below the surface of the ground, but they also tunnel into the tubers, causing serious injury to the crop, which should be harvested as early as possible. See Tobacco.

\section{Primrose}

Greenhouse whitefly, Trialeurodes vaporariorum. This insect infests primroses in greenhouses. See Tomato.

Slugs. In the garden, primroses are often eaten by garden slugs. See Lettuce.

\section{Privet}

Leaf roller, Archips rosana. This small caterpillar in May webs together the terminal leaves of California privet, making a case within which it lives and feeds. When fully grown it is three-fourths of an inch in length, and green with a dark brown head. It pupates in the webbed leaves and the moths emerge about the middle of June. In color the fore-wings vary from light brown to olive brown and are crossed by darker markings. The eggs are laid in June on the twigs and remain there and hatch the following spring.

As most of the webbed leaves are clipped off in trimming the hedge, no other control measures are necessary.

Lilac borer, Podosesia syringae. This insect is also an occasional borer in privet. See Lilac.

Mites. Phyllocoptes schlectendali. This mite infests the tender tips of California privet in spring and early summer, which results in the leaves being stunted, thickened and curled, and some of them dropped. At the first trimming most of the infested tips were removed and the work of this mite was not again noticeable until the following spring.

Thrips, Dendrothrips ornatus. This insect injures privet, and may be controlled by spraying with nicotine sulfate and soap. 
White or West Indian peach scale, Aulacaspis pentagona. This scale occasionally infests privet. See Peach.

\section{Pumpkin}

Aphids. Several kinds of aphids may occur on pumpkin, such as the melon aphid, Aphis gossypii; the squash aphid, Macrosiphum cucurbitae, and the potato aphid, Macrosiphum solanifolii. See Squash.

Melon worm, Diaphania hyalinata. This insect also infests pumpkin. See Melon.

Squash borer, Melittia satyriniformis. This borer may cause serious injury to squash and pumpkin, but as pumpkin is usually planted late it escapes injury more often than squash. See Squash.

Squash bug, Anasa tristis. The squash bug commonly injures pumpkin. See Squash.

Squash lady beetle, Epilachna borealis. This insect sometimes feeds upon pumpkin. See Squash.

Striped cucumber beetle, Diabrotica vittata. This insect may injure pumpkin if plants are grown early in the season. See Cucumber.

\section{Quince}

Aphids. Quince is infested by the green apple aphid, Aphis pomi, the apple grain aphid, Rophalosiphum prunifoliae, and the woolly aphid, Eriosoma lanigera, all of which infest the apple. See Apple.

Codling moth, Carpocapsa pomonella. The codling moth also infests the quince. See Apple.

Oriental fruit moth, Grapholitha molesta. This is now the the most destructive insect pest of quince in Connecticut. See Peach.

Quince curculio, Conotrachelus crataegi. Until the advent of the Oriental fruit moth, this was the most destructive quince insect in Connecticut, and now must take second place. The beetles appear in midsummer and lay eggs singly, usually about the middle of July. The eggs hatch in from seven to ten days and the grub tunnels through the flesh, rarely reaching the core. Few of the infested fruits drop and in about 30 days, usually in August, the mature larvae begin to leave the fruit and make cells two or three inches deep in the soil where they hibernate and pupate the following spring. From 10 to 20 days after pupation the adults emerge. The grubs are flesh-colored and without legs. The adult beetle is about one-fourth of an inch in length and brownish gray in color. There is only one brood each year.

Although this pest is difficult to control, thorough and repeated applications of lead arsenate will greatly reduce the injury.

Resplendent shield bearer, Coptodisca splendoriferella. The tiny caterpillars of this insect are leaf miners and when fully grown cut out shieldshaped portions of the leaf for cases which they fasten to the bark. The second brood caterpillars hibernate in these cases. The little moths emerge in May, and the basal half of their fore-wings are lead gray and the apical half golden with streaks of dark brown and silver. Control measures have not been worked out and are not needed except in cases of severe outbreaks.

Possibly a spray of nicotine sulfate and soap may penetrate sufficiently to kill some of the miners.

San José scale, Aspidiotus perniciosus. The San José scale commonly infests quince. See Pear. 


\section{Radish}

Aphids. The following species of aphids have been recorded from radish; the turnip aphid, A phis pseudobrassicae; the spinach aphid, Myzus persicae; and the milkweed aphid, Myzocallis asclepiadis.

Ustually the plants grow so rapidly that they are ready to harvest before they are seriously injured by aphids. If such is not the case, an application of nicotine dust should be given.

Cabbage maggot, Hylemyia brassicae. This insect often injures radish. See Cabbage.

Diamond-back moth, Plutella maculipennis. This insect feeds upon radish. See Cabbage.

Garden springtail, Sminthurus hortensis. Young radish plants are often severely injured by this insect. See Beet.

Potato flea beetle, Epitrix cucumeris. The potato flea beetle often feeds upon radish. See Potato.

Radish maggot, Anthomyia radicum. This insect sometimes causes severe injury to radish in a manner similar to that of the cabbage maggot. See Cabbage.

\section{Raspberry}

Aphids. At least two species of aphids occur on raspberry, though they are seldom abundant, and their direct injury is not so much to be feared as the probability that they may transmit and spread the mosaic and related diseases. These aphids are Aphis rubicola and Nectarosiphon $r u b i$, and both are found scatteringly on the under sides of the leaves.

Control consists of spraying with nicotine sulfate and soap, or applying nicotine dust.

Raspberry cane borer, Oberea bimaculata. This insect is one of the long-horned beetles which appear in June and the female makes two rows of punctures around the tip of the shoot about half an inch apart, then lays an egg in the stem between the girdles. The tip wilts and this injury is thought to protect the egg from being injured by a too rapid growth of the shoot. The egg hatches in early July and the grub burrows downward in the pith and hibernates in the cane only an inch or two below the girdle. The second season it continues to burrow downward, usually killing the cane, and reaches the ground by the second winter and hibernates in the burrow. The following spring it pupates in the burrow and the adult beetle may emerge in May or June. Two years are required for the complete life cycle. The adult beetle is about half an inch long and has black wingcovers and yellow thorax, usually with two or three black spots.

The only control is to cut out and burn the wilted fruiting canes, and also the wilted tips, cutting below the lower girdle.

Raspberry cane maggot, Hylemyia rubivora. The adult of this insect is a two-winged fly that appears late in April and when the raspberry shoots are a few inches tall, lays an egg in the axil of one of the tip leaves. The egg soon hatches and the maggot crawls down the stem for a short distance, then goes into the stem and tunnels downward in the pith. It works its way nearly to the bark and cuts a tunnel around the shoot, thus girdling it, and the tip wilts. The maggot reaches maturity in late June or early July, pupates in the burrow and the adult fly emerges the following spring. There is one generation each year.

The only control is to cut several inches below the girdle and burn all wilted tips in May.

Raspberry fruit worm, Byturus unicolor. Raspberry plants are often injured by small brown beetles that eat holes in the tender terminal leaves and devour the blossoms. The female lays eggs in May on the base of the 
blossom buds, on bud and leaf stems, in cavities in buds or on leaves. After the buds open, eggs are laid in the blossoms. The eggs soon hatch and the larvae work and develop inside the fruit and the fleshy receptacle, often causing the fruit to dry up. The larvae often adhere to the picked fruit, and are light yellow with a cross band of light brown on the back of each segment, and are about one-fourth of an inch in length. The beetles are light brown, hairy, and about one-sixth of an inch in length.

Four applications of lead arsenate before the blossoms open greatly reduce the amount of injury. See Bulletin 251 of this Station.

Raspberry root borer, Bembecia marginata. The raspberry root borer tunnels in the main roots and crowns of blackberry and raspberry plants. The adult is a clear-wing moth having a wing spread of an inch, with transparent wings and black body crossed by four yellow bands. It emerges in August and deposits eggs underneath the leaves. The first winter the small larvae hibernate in blister-like elevations of the bark just beneath the soil level or in crevices or under flakes of bark at the base of the stems. In the spring they tunnel in the stems and roots just beneath the bark, often girdling the plants. They hibernate in their burrows the second winter and the following spring tunnel upward either in the pith or just under the bark, finally reaching a length of nearly an inch. In July they burrow to the surface and pupate in the tunnel. When ready to emerge the pupa works its way partly out of the tunnel when the case splits open and the moth escapes, leaving the pupa case protruding from the burrow. Infested bushes usually wilt at the top or die, and the only remedy is to dig out the borers or remove and burn the infested plants.

The destruction of wild plants around the berry patch will aid in the control of this insect.

Raspberry sawfly, Monophadnoides rubi. Serious injury is often caused by green spiny larvae, about three-fourths of an inch long that feed on the leaves. The adult is a black sawfly about one-fourth of an inch in length which in May lays eggs singly in the leaf tissue near a prominent vein. The eggs hatch in a week or so and the larvae feed upon the leaves. When abundant they may devour all of the foliage. They reach maturity in about 10 days, go into the ground where they hibernate, and pupate the following spring. There is one brood each season.

The remedy is to spray with lead arsenate before the plants blossom. If later treatments are needed, hellebore should be used.

Tree cricket, Oecanthus nigricornis. Of several species of tree crickets occurring in Connecticut, this one has the habit of laying its eggs in small twigs of raspberry and blackberry canes. The egg punctures either kill the cane above this point or so weaken it that the fruit cannot develop. The canes often break off at the egg punctures. This tree cricket is yellow with black legs and antennae and is about five-eighths of an inch in length.

In pruning the canes, those containing eggs should be cut off and burned.

\section{Redtop}

For insects injuring redtop, see Grass.

\section{Rhododendron}

Azalea bark scale, Eriococcus azaleae. This scale infests rhododendron. See Azalea.

Rhododendron borer, Sesia rhododendri. Rhododendron stems are sometimes severely injured by white grubs that tunnel under the bark. Severe wounds are formed and the top or side branches wilt and sometimes break off. The grub matures in October, and is then about half an inch long, but it hibernates in the burrow and pupates in the spring. The moths 
appear in May and June and the females lay eggs on the twigs. The moth is a clear-wing and has a wing spread of about half an inch, wings transparent with brown margins. There is one brood each year.

The only known method of control is to cut out the borers and injured stems and burn the refuse. The wounds should be coated with tree paint or with paraffin.

Rhododendron lacebug, Stephanitis rhododendri. The adults and nymphs of this lacebug suck the sap from the under sides of the leaves. The results of infestation show on the upper leaf surface as a mottled or white peppered appearance, and on the under surface the leaf is brownspotted with excrement. The winter is passed in the form of eggs inserted on the under side of the leaf, usually near the midrib. They hatch in May and the nymphs become mature in June and lay eggs in June and July for the second brood, the nymphs of which appear in August. These nymphs become mature later and the adults lay eggs in the leaves that hatch the following spring.

The control measures consist in spraying the under sides of the leaves to kill the nymphs and adults, using nicotine sulfate and soap.

\section{Rhubarb}

Aphids. The bean aphid, Aphis rumicis, and the spinach aphid, Myzus persicae, sometimes infest rhubarb.

Spraying with nicotine sulfate and soap will control them.

European corn borer, Pyrausta nubilalis. The European corn borer tunnels in rhubarb stalks. See Corn.

Rhubarb curculio, Lixus concavus. The rhubarb curculio makes feeding and egg punctures in the stalks and the sap exudes from the wounds as glistening drops of gum. The eggs laid in rhubarb do not hatch but are killed by the sap. The beetle is about half an inch in length, black, covered with a yellow dust, and hibernates as an adult. It feeds upon the margins of the leaves besides puncturing the stalks. There is no remedy other than gathering the beetles by hand and destroying them.

Stalk borer, Papaipema nitela. The stalk borer also infests rhubarb. See Dahlia.

Yellow woolly bear, Diacrisia virginica. The caterpillars sometimes feed upon rhubarb. See Verbena.

\section{Rose}

Aphids. Several species of aphids infest rose. In the early summer it is a common sight to see the new shoots and leaves thickly infested. The more common aphids on rose are Myzus rosarum, Macrosiphum rosae, and the potato aphid, $M$. sotanifolii. Another species, Macrosiphum dirhodum, also occurs on rose.

These aphids may be controlled by spraying thoroughly with nicotine sulfate or pyrethrum-soap.

Fuller's rose beetle, Asynonychus godmani. Roses and many other plants in greenhouses are sometimes injured by Fuller's rose beetle which feeds on the leaves at night and rests in the leaves or in some protected place during the day. The eggs are laid under the edges of bark near the ground and the larvae live in the soil and feed upon the roots of various plants. The life history and length of the larval period are not well known, but it is said that all stages occur in the greenhouse during the winter and early spring. Adults are the most abundant in December. This is a brown snout beetle marked with patches of gray scales, and in length it varies from one-fourth to three-eighths of an inch. 
Control measures consist of spraying the foliage with lead arsenate to kill the beetles, and treating the soil with carbon disulfide or some other soil insecticide to kill the larvae.

Green fruit worms, Xylina sp. Green caterpillars with a yellow stripe along each side occasionally climb up the stems and eat holes into the buds. See Apple.

Japanese beetle, Popillia japonica. This beetle in the adult stage feeds upon a great variety of trees and plants, and rose is one of its favorites. The beetle is about half an inch in length, bright, shining green, with wing-covers a bronzy red or copper color. Two white spots on the tip of the abdomen show beyond the ends of the wing-covers, and there are five white spots formed by patches of white hairs on each side of the abdomen. The beetles begin to emerge the latter part of June; their greatest abundance is usually about the middle of July, but in certain seasons may occur later. Thereafter they gradually decrease and about October 1 disappear altogether. The eggs are laid in July in the soil, and the grubs feed on grass roots near the surface, going downward to a depth of about a foot to hibernate. In the spring just before May 1, they ascend to the surface, feed for a time, then enter the prepupal stage, and pupate late in May or early in June. From two to four weeks later the adults emerge. There is one generation each year.

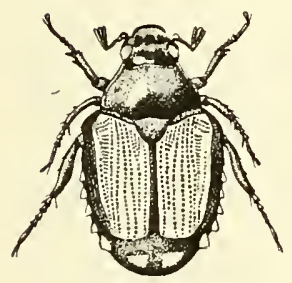

Figure 76.

Japanese beetle.

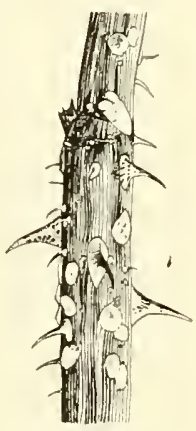

Figure $7 \pi$.

Rose scale.

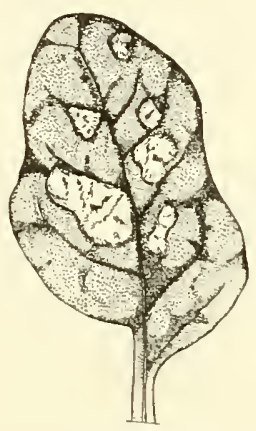

Figure 78 .

Spinach leaf miner.

For treatment of lawns to prevent injury, lead arsenate should be used as described under Asiatic beetle. To protect trees and shrubs from injury by the beetles, spray with coated lead arsenate. (Fig. 76.)

Rose chafer, Macrodactylus subspinosus. When very abundant, this insect injures roses and many other shrubs and trees by the beetles skeletonizing the leaves. They also cause injury to the flowers, particularly white flowers, by feeding upon the petals and soiling them with excrement. Rose chafers breed most abundantly in sandy waste land but often occur in lawns; they appear each year about June 10 to 12 , and feed for about a month, though some of the beetles are present for six weeks. The females each lay from 24 to 36 eggs singly in the ground a few inches beneath the surface. They soon hatch and the young grubs feed upon the roots of grass and other plants, becoming full grown by late autumn when they go into the ground several inches to hibernate. The next April or May they come near the surface and transform to pupae in earthen cells, and from two to four weeks later the beetles emerge. The adult beetle is yellowish grayish brown or clay colored and is about one-third of an inch long, with long 
sprawling legs. The larva is a white grub about three-fourths of an inch in length when full grown.

The common remedy is hand picking. Foliage may be protected by spraying heavily with lead arsenate or coated lead arsenate. Deep cultivation of the ground the last week in May will kill many of the pupae. White flowers may be protected for cutting by covering the plants or bushes with netting. Certain sprays of impregnated oil or pyrethrum-soap may be applied to the flowers without injury or discoloration. (Fig. 38.)

Rose curculio, Rhynchites bicolor. This snout beetle has the habit of eating holes into the buds of rugosa and some other kinds of roses. It is about one-fourth of an inch in length and is red with a black snout.

Hand picking is the usual method of control, but in severe infestations it will probably pay to spray with lead arsenate.

Rose leafhopper, Typhlocyba rosae. The adults and nymphs are usually on the under sides of the leaves. On the upper side there is usually a white peppered effect that indicates the presence of the leafhoppers. All suck the sap, and severely injured leaves drop prematurely. There are two generations each season and the insect hibernates in the egg stage.

Perhaps the best control is to spray the under sides of the leaves with pyrethrum-soap or nicotine sulfate and soap. (Fig. 75.)

Rose leaf rollers. Several species of leaf rollers injure roses. In 1929, material was collected from a garden where most of the roses seemed to be infested, and from this material was reared Archips rosana, Tortrix albicomana and Epiblema suffusana. The oblique-banded leaf roller, Cacoecia rosaceana, is also a common leaf roller of rose, and probably several other species may at times injure roses in this manner. All are the larvae of small moths belonging to the family Tortricidae.

The usual control measure is to gather and burn the rolled leaves, but in case of a severe infestation the plants should be sprayed with lead arsenate.

Rose midge, Dasyneura rhodophaga. This is a serious pest of roses in the greenhouse, and is known to injure out-door roses in Canada. The small fly lays yellow eggs on the tender growth near the flower buds. These hatch in two days and the young larvae feed at the base of flower buds or leaf stems causing them to become distorted and later to turn brown and die. Often there are 20 to 30 white maggots in an infested bud. The maggots mature in about a week and construct small white cocoons on the soil and a week later the flies emerge. In greenhouses only about two weeks are required for the life cycle and the number of generations is not known. The chief injury occurs between May and November and the flies are seldom seen during the winter.

Control consists in fumigating each night with nicotine or tobacco fumes and in mulching the soil with tobacco dust.

Rose sawflies. The rose sawfiy, Caliroa aethiops, the bristly rose slug, Cladius isomerus, and the curled rose sawfly, Emphytus cinctipes, in their larval stage all feed upon the leaves of rose, some of them skeletonizing the leaves at first and later eating holes or notches in the margins. The first species has one brood and the others two or more broods each season.

The remedy is to spray with hellebore or lead arsenate, but in most cases where it is necessary to spray for aphids the pyrethrum-soap or nicotine sulfate will probably kill the larvae.

Rose scale, Aulacaspis rosae. The female scale is nearly circular, flat, white, and about one-twelth of an inch in diameter. The males are much smaller and are narrow and elongate. They suck the sap from the plant and are often numerous on the stems of rose and blackberry in sheltered situations. There are probably three complete broods each year and all stages may be found under the shells during the winter.

It is best to cut out and burn the old and badly infested stems. Others should be sprayed in early spring with lime-sulfur or miscible oil. (Fig. 77.) 
Rose stem girdler, Agrilus communis ab. rubicola. The grub of this beetle tunnels in the twigs of rose especially rugosa and hugonis, causing swellings or galls. The twigs often break off at this point and in some cases they die beyond the gall but do not break. The beetles appear in June and July. The larvae make spiral tunnels just under the bark and two years are thought to be required for larval development. The beetle is from onefourth to one-third of an inch long, and metallic or copper green in color.

The only known remedy is to clip off and burn the infested twigs in winter or spring before the beetles emerge.

\section{Rubber Plant}

Circular scale, Chrysomphalus aonidum. This is a circular, dark reddish brown scale that stands out prominently from the leaf; the nipple is pointed; in fact, the profile of the scale is almost conical. This scale commonly infests rubber plants, palms, oleander, camellia, and citrus trees.

Fumigating the house with cyanide gas, or thoroughly spraying with nicotine sulfate and soap or with pyrethrum-soap will control this scale.

Mealybugs. Pseudococcus sp. Rubber plants are commonly infested with mealybugs. See Lantana.

Morgan's scale, Chrysomphalus dictyospermi. This scale resembles the circular scale, but is much flatter. The same treatment will control it.

Soft scale, Coccus hesperidum. This scale of ten infests the rubber plant. See Fern.

\section{Rye}

Aphids. Macrosiphum granarium infests rye, and probably Rophalosi. phum prunifoliae, Toxoptera graminum, and the spinach aphid, Myzus persicae, may sometimes occur on rye.

Armyworm, Cirphis unipuncta. When abundant this insect will cause severe injury by feeding upon rye. See Grass.

Wheat midge, Thecodiplosis mosellana. The wheat midge also intests rye. See Wheat.

\section{Salsify}

Tarnished plant bug, Lygus pratensis. This insect sometimes injures salsify. See Âpple and Peach.

Yellow woolly bear, Diacrisia virginica. The caterpillars of this insect feed upon salsify. See Verbena.

\section{Serviceberry}

(Shadbush)

Fall webworm, Hyphantria cunea. This insect feeds upon serviceberry. See Pear.

Gipsy moth, Porthetria dispar. Gipsy moth caterpillars feed upon serviceberry. See Apple.

Round-headed borer, Saperda candida. This borer tunnels in the trunk of serviceberry. See Apple.

Serviceberry gall mite, Eriophyes amelanchieri. This mite forms small globular galls on the upper leaf surface, about one-twelfth inch in diarneter, usually reddish above and light greenish yellow below.

No remedy can be recommended. 


\section{Snapdragon}

Cyclamen mite, Tarsonemus pallidus. The cyclamen mite often injures snapdragon. See Cyclamen.

\section{Snowball}

Aphids. The snowball aphid, Aphis viburniphila, sucks the sap from the new leaves and shoots in spring, ruins the bloom, and causes both leaves and shoots to curl. Another species, Anuraphis viburnicola, also infests the various species of viburnum.

The remedy is to spray with nicotine sulfate and soap, or, better still, where possible dip the ends of the twigs into the mixture.

\section{Snowberry}

Aphids. At least two kinds of aphids infest snowberry. One is Aphis sy'mphoricarpi, and the other, Siphocoryne xylostei.

In case they become abundant a spray of nicotine sulfate and soap will control them.

San José scale, Aspidiotus perniciosus. The San José scale infests snowberry, and may be controlled by spraying with nicotine sulfate and soap.

Snowberry clear-wing, Hemaris diffnis. The caterpillars of this moth feed upon snowberry and Tartarian honeysuckle, and are called horn worms because each has a horn on the tail after the manner of sphinx caterpillars. There are two broods each season and the insects hibernate as pupae in the ground. The moths emerge in May and lay eggs on the food plant; the caterpillars feed until the middle of June, when they pupate. The moths soon emerge and lay eggs for the second brood of larvae. The caterpillars vary from dark green with lighter green on the back to brown or purplish, with spiracles very prominent. The moths have a wing spread of from one and one-half to two inches. All wings are transparent with dark brown margins. The body is black marked with golden pubescence.

The usual remedy is hand picking, but a spray of lead arsenate will prevent defoliation.

\section{Soy Bean}

Corn ear worm, Heliothis obsoleta. The corn ear worm is known to feed upon soy bean in the southern states. See Corn.

Green clover worm, Plathypena scabra. The green clover worm feeds upon soy bean. See Bean.

Mexican bean beetle, Epilachna corrupta. This insect feeds sparingly on soy bean. See Bean.

White grubs, Phyllophaga sp. White grubs sometimes eat off the roots of soy bean. See Grass.

\section{Spearmint}

Four-lined plant bug, Poecilocapsus lineatus. This bug often injures the terminal leaves of spearmint. See Currant.

Garden flea hopper, Halticus citri. This is a small jumping plant bug. The female is dimorphic. The long-winged form is about one-twelfth of an inch in length, and semi-transparent wing-tips extend beyond the tip of the abdomen. The short-winged form does not have membraneous wings extending beyond the abdomen and is consequently shorter than the long-winged form. This bug feeds upon a vast number of flowering plants, 
vegetable plants and weeds. The life history and number of broods of this insect is not known. Probably it passes the winter in the egg stage in the stems of some of its host plants. Adults are present from May until October.

Spraying the plants thoroughly with nicotine sulfate and soap will control this insect.

\section{Spinach}

Garden springtail, Sminthurus hortensis. This little insect often injures spinach seedlings. See Beet.

Potato flea beetle, Epitrix cucumeris. This common flea beetle feeds upon spinach. See Potato.

Spinach aphid, Myzus persicae. This is perhaps the most common and destructive aphid on spinach, although it infests many other kinds of plants, and several other kinds of aphids infest spinach. The bean aphid, Aphis rumicis; the melon aphid, Aphis gossypii; and the potato aphid, Macrosiphum solanifolii, all occasionally infest spinach.

A heavy application of nicotine dust with a long sheet dragged from the dusting machine to hold in the dust and fumes is probably the best method of control for these aphids.

Spinach flea beetle, Disonycha xanthomelaena. This greenish black beetle with yellow thorax is about one-fifth of an inch in length and hibernates as a beetle. It appears in the field in early spring and deposits clusters of orange-colored eggs on the ground at the base of the plant. The larvae crawl to the plant and feed upon the under side of the leaves. At first they eat off only the surface, but as they become larger they eat holes through the leaves. In a month or less they become mature and are less than a half inch in length. When disturbed, the larvae drop to the ground and remain hidden until the danger is over. They enter the soil and pupate in earthen cells near the surface. There are two generations in Washington, but the number in Connecticut is not known.

Control measures have not been demonstrated as yet.

Spinach leaf miner, Pegontyia hyoscyami. This is the most destructive insect pest of spinach. It also infests beet, chard, and the common weed called lamb's quarters. There are three or four generations each season and the insect winters in the soil in the pupa stage. The adult is a gray two-winged fly, about one-fourth of an inch in length, that emerges in April or May and lays white, cylindrical, reticulated eggs in clusters of from two to five on the under side of a leaf. They hatch in four to six days and the young maggots enter the tissue of the leaf and make blotch mines which often involve the entire leaf, especially as there are usually two or more larvae in the same leaf. If the food becomes exhausted they migrate to other leaves. The larva matures in a period that varies from 7 to 16 days, and is then about a third of an inch long. It then descends two or three inches into the soil and pupates, and the flies emerge from 14 to 25 days later.

No satisfactory method of control has been developed. It is advisable to gather and burn the injured leaves and keep the field and its environs free from weeds. It is possible that spraying with some impregnated oil or with nicotine sulfate and soap may destroy the maggots, but the material is yet to be demonstrated. (Fig. 78.)

\section{Spiraea}

Aphids. At least two species of aphids infest spiraea and probably there are several others. These are, Aphis spiraecola and Macrosiphum spiraecola. 
Control comes from spraying with nicotine sulfate and soap.

Spiraea leaf roller, Olethreutes hemidesma. In certain seasons in August the larva of this insect webs together the leaves of the new shoots of Spiraea vanhoutei, and probably other spiraeas and lives and feeds inside the nests.

The remedy is to clip off and burn the nests, or spray with lead arsenate in July to prevent their formation.

Spiraea scale, Eriococcus borealis. This scale sometimes infests Spiraea thunbergi and probably other spiraeas, gathering in the forks of the twigs and stems. This is a white mealy scale closely resembling the azalea scale.

It may be controlled by a spray of pyrethrum-soap or by nicotine sulfate and soap.

\section{Spruce}

Aphids. One species, Dilachnus pinicola, has been collected on spruce in Connecticut, but evidently aphids are not a serious pest on spruce.

Should they occur in great numbers, spraying with pyrethrum-soap or nicotine sulfate and soap will control them.

Eastern spruce beetle, Dendroctonus piceaperda. This small bark beetle emerges in June and July in large numbers from small round holes, resembling shot holes. Weak trees of the native red, white and black spruce in particular are infested and the insect seems to prefer trees a foot or more in diameter. Infested trees show exuding gum more or less mixed with sawdust on the trunk. The females lay eggs in June and July and the grubs tunnel under the bark after the manner of bark beetles, hibernating in the burrows as adults and in a partially grown condition and completing their development the following spring. There is one brood each year.

Infested trees should be cut, and the bark removed before the middle of May in order to prevent the beetles from reaching maturity.

Gall aphids. There are several species of aphids that form galls on spruce twigs. By far the commonest is Adelges abietis, called the spruce gall aphid, that makes a pineapple-shaped gall at the base of the new growth on Norway spruce. A rather large terminal gall on blue spruce is caused by a closely related species, Gillettea cooleyi, which spends a portion of its life cycle on Douglas fir. The spruce gall aphid hibernates in the form of immature females on the twigs near the buds. They mature in the spring and lay eggs that hatch soon after the new growth begins in May. The young attach themselves to the base of the needles and form a gall. About the first week in August these galls break open and the mature nymphs crawl to the needles. They molt and transform to sexual winged females that lay eggs on the needles for the over-wintering generation. Thus there are two generations each season.

The most approved method of control consists of spraying early in April with a miscible oil, 1 part in 25 parts water, or nicotine sulfate and soap. (Fig. 79.)

Gipsy moth, Porthetria dispar. The caterpillars of the gipsy moth feed upon spruce. See Apple.

Spruce budworm, Harmologa fumiferana. This insect has caused severe injury to spruce and balsam fir in the northern forests several times during the last 60 years. The young caterpillars feed upon the needles of the new growth of the terminal shoots and those of the preceding season, usually webbing these leaves together and eating them off at the base. The webs holding the severed leaves and bud scales give the trees a sickly appearance and in fact weaken the trees to such an extent that they become the prey of bark beetles and other secondary destroyers. The caterpillars at maturity are about three-fourths of an inch in length, and are dark brown bearing cream colored tubercles. The adult moths have a 
wing spread of about three-fourths of an inch, and are brown marked with gray and white spots. They are most abundant in June and July and the females lay clusters of pale green flat eggs upon the needles. These eggs hatch in 10 days, and the caterpillars hibernate in a partially grown condition. There is one generation each year. Mixed stands with reduced percentage of balsam fir are recommended for forest planting. July.

Shade trees can probably be protected by spraying with lead arsenate in

Spruce epizeuxis, Epizeuxis aemula. The larvae of this moth web together and feed upon the needles. The larvae are brown and covered with warts or tubercles and resemble the spruce bud worm. The moth has a wing spread of less than an inch, and is brownish gray, with both front and rear wings crossed by several narrow wavy bands or lines.

A spray of lead arsenate will probably prevent injury.

Spruce leaf miner, Epinotia nanana. The larva of this insect as well as those of several other species mine the needles, causing them to fall in great numbers, though not noticeably defoliating the branches. Little is known about the life history or means of control.

Probably a spray of lead arsenate and nicotine sulfate will control them.

Spruce mite, Paratetranychus ununguis. Considerable injury is caused each season to conifers in ornamental plantings by the spruce mite, which feeds upon the leaves and webs them over somewhat after the manner of the common red spider. The trees take on a faded grayish appearance and later have a brownish cast. Various sprays have been recommended for the control of this mite. Some of these are as follows: Volck; glue, one pound in 10 gallons water; linseed oil emulsion.

Spruce sawfly, Neodiprion abietis. The larvae of this sawfly are dark green with darker longitudinal stripes and head, and when mature are about half an inch in length. They feed upon the leaves of spruce, balsam fir, and, to some extent, pitch pine. The adult is a small black sawfly.

A spray of lead arsenate will protect the leaves from injury.

Twig injury by squirrels. Often in winter spruce $t$ wigs of the preceding season's growth fall in great numbers and look exactly if they had been clipped off. This is the work of squirrels that feed upon the large terminal or lateral buds. Probably the squirrels cannot reach them without cutting and dropping them to the ground.

No remedy is known except to see that the squirrels have a supply of nuts or other food at times when it is difficult for them to find a supply of food.

White pine weevil, Pissodes strobi. This insect frequently infests the leaders of Norway and other kinds of spruce. See Pine.

\section{Squash}

Aphids. There are several species of aphids that infest squash. Some of these are the squash aphid, Macrosiphum cucurbitae; the potato aphid, Macrosiphum solanifolii; and the melon aphid, Aphis gossypii.

Dusting with nicotine dust or under-spraying the leaves with nicotine sulfate are the usual methods of control.

Garden springtail, Sminthurus hortensis. The garden springtail feeds upon the young plants. See Beet.

Greenhouse whitefly, Trialeurodes vaporariorum. This insect often injures squash. See Tomato.

Melon worm, Diaphania hyalinata. The larva of this insect infests squash. See Melon.

Pickle worm, Diaphania nitidalis. This insect also infests squash. See Cucumber. 
Squash borer, Melittia satyriniformis. This is the most important insect pest of squash in Connecticut. The moths appear the last of June and during July lay eggs on the leaf stems and under side of the leaves, and on the main stalk, usually on the basal portion of the vine. The eggs hatch in from 6 to 15 days and the larvae enter the stems where they are borers until they reach larval maturity, a period of from four to six weeks. They are white with dark brown head, and are about an inch in length. They descend about two inches into the soil, spin a cocoon and remain there until the following spring when they pupate. There is one generation each year in Connecticut. In late July, August and September, the vines wilt one by one and die from the ravages of the borers.

The usual control measures have been to examine the vines and cut out the borers wherever sawdust indicates their presence, and to cover the main stem with soil as soon as it begins to run along on the ground, in order to induce new roots to form at the nodes. Another method of control consists in spraying the basal four feet of each vine thoroughly, covering all stems and both sides of the leaves. For this purpose probably nicotine sulfate, one part in 100 parts of water to kill the eggs, four applications at weekly intervals in July, is preferable. Good results have also been obtained with lead arsenate to kill the young larvae before they enter the stems. Perhaps a combination of these two materials is advisable. (Fig. 82.) See Bulletin 328 of this Station.

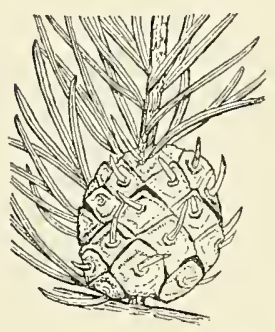

Figure 79.

Spruce aphid gall.

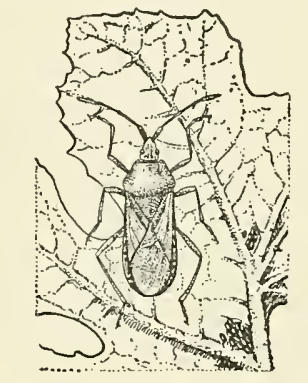

Figure 80. Squash bug.

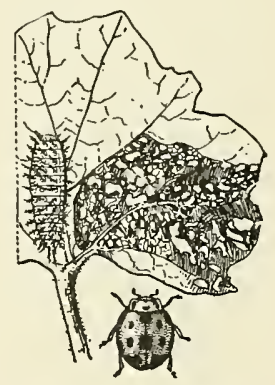

Figure 81.

Squash lady beetle.

Squash bug, Anasa tristis. The squash bug or "stink bug" is a dark brown bug about five-eighths of an inch in length that hibernates in protected places. The old bugs feed upon the young plants as soon as they appear above ground, and often kill them. The bug punctures the plant with its beak and sucks the sap. Later, after the plants have formed some large leaves, the female bugs lay clusters containing from 5 to 50 brown shiny eggs on the under side of the leaves. The eggs hatch in from 6 to 15 days, and the young at first are green and pink, but after a few hours the pink changes to black. After the first molt the young bugs are ash-gray. There are five molts and four or five weeks are passed in the nymphal stage. There is only one annual generation. Usually the bugs that hatch from an egg-cluster remain together and feed in clusters for a time, but later separate and often hide in the soil around the base of the plants. The effect of so many bugs all sucking the sap, is to injure the plant, which often wilts and dies. All old vines and trash should be burned after the crop is harvested.

Young nymphs may be killed by spraying with nicotine sulfate, 1 part in 400 parts of water, with soap, thrown against the under sides of the leaves by means of an angle rod with upturned nozzle. (Fig. 80.) 
Squash ladybeetle, Epilachna borealis. The squash ladybeetle and the Mexican bean beetle are the only two kinds of ladybeetles in Connecticut that injure plants. All of the others are beneficial and devour aphids and scale insects. The squash ladybeetle hibernates under the bark of dead trees, stumps and other sheltered places and emerges in June and lays eggs on the under side of the leaves. The eggs hatch in about 12 days and the larvae feed upon the under side of the leaves. The adults are present at the same time, and later feed upon the upper side. They have the habit of marking out with their mandibles definite areas, then feed within these areas, often fully skeletonizing them. The larvae usually appear in Connecticut about the middle of July and mature in about three weeks. They are then about three-eighths of an inch long, bright yellow with six rows of long, black, branched spines. The pupa is also yellow and is attached by the posterior end to the under side of a leaf. The adult is dull yellow, marked with 12 black spots. There is one generation each season.

This insect may be controlled by spraying with lead arsenate. (Fig. 81.)

Striped cucumber beetle, Diabrotica vittata. This beetle causes severe injury to the young squash seedlings. See Cucumber.

\section{Strawberry}

Aphids. The strawberry root aphid, Aphis forbesi, is often a serious pest of strawberry. Certain other aphids like Myzus porosus infest strawberry, but will hardly require treatment. The root aphid can best be controlled by setting clean plants on uninfested land.

Garden millipede, Julus hortensis. This millipede often injures strawberry plants, especially where the crown is infested with the crown borer. See Tulip.

Strawberry crown borer, Tyloderma fragariae. The grubs of this snout beetle tunnel downward through the crown of the plant and by the time they are full grown the plants are severely injured. From one to three grubs may tunnel in a plant. The mature grub is about one-fifth of an inch long and is white with a yellow head. The grubs mature in July and transform to beetles within the burrow. The beetles remain there for a time and then emerge, but on the approach of winter go into the soil to hibernate. The beetles are chestnut brown in color and about one-sixth of an inch in length. They appear in early spring and the females lay eggs singly in cavities eaten in the plant near the surface of the ground. There is one annual generation.

There is no remedy except to adopt the one-crop system, and to dig the new plants in the early spring before the eggs are laid, and set them some distance away from the infested beds.

Strawberry crown girdler, Brachyrhinus ovatus. The larvae of this snout beetle often eat off the roots of strawberry plants. The adults appear in June and again in August and September, which indicates that there are two broods, but the life history has not been fully worked out. The insects hibernate both as larvae in the soil and as adults in sheltered places. The beetle is dark brown and about three-sixteenths of an inch in length. The full-grown grub is about one-fourth of an inch long, white with yellow head. The recommendations for controlling the crown borer are applicable here. Renew the beds each year and avoid planting on sod land.

Strawberry flea beetle, Haltica ignita. This small metallic blue or green flea beetle in early spring feeds upon the leaves of strawberry, often riddling them. It is about one-sixth of an inch in length, and the females lay eggs on the leaves of the evening primrose, upon which the larvae feed. When mature they enter the ground to pupate and hibernate and the adults emerge the following spring. There is one annual generation.

Spraying with lead arsenate will protect the foliage. 
Strawberry leaf roller, Ancylis comptana. The two halves of strawberry leaflets are often folded and webbed together and greenish or brownish caterpillars live and feed inside. These leaves soon turn brown and die and in severe infestations the fruit fails to mature. The adult moths appear in May and the females lay eggs singly on the under side of the leaves. The eggs hatch in about a week, and the larvae feed for about a month. When fully grown they are about half an inch in length, and vary in color from yellowish green to greenish brown with brown head. They transform to brown pupae within the folded leaves and 10 days later the moths emerge. There are probably two generations each year in Connecticut, and the insect hibernates both as a larva and as a pupa. The moth is light reddish brown with fore-wings marked with wavy lines of darker brown and white, and with wing spread of slightly more than half an inch.

This insect can be controlled by spraying with lead arsenate in spring about a week after the moths first appear.

Strawberry sawfly, Empria maculata. The larvae of this sawfly feed upon strawberry leaves. The adults emerge in early spring and the females lay eggs in the leaf stems. In two weeks the eggs hatch and the larvae eat small round holes in the leaves, later destroying the entire leaves. They become full grown the last of June, when they are about three-fourths of an inch in length, and pale green to grayish yellow in color. They go into the ground and make their cocoons and pupate the following spring. The adult is a small black sawfly. There is only one generation each year.

This insect is easily controlled. In early spring and before the fruit is half grown it is safe to apply lead arsenate. When the fruit is nearly grown, it is safer to use hellebore.

Strawberry weevil, Anthonomus signatus. This weevil lays an egg in the flower bud, then eats the pedicel partly off. In severe infestations this insect may cause a loss of 50 to 60 per cent of the crop. The beetle is about one-tenth of an inch in length, and varies in color from black to reddish brown. The larva feeds almost entirely on pollen and the eggs are laid almost wholly in the buds of staminate varieties. The adult hibernates and there is only one generation each year. This inseci injury may for the most part be avoided by planting a large proportion of varieties with imperfect flowers for the main crop. Some perfect flowered varieties will be necessary for pollination.

Strawberry whitefly, Trialeurodes packardi. This whitefly is occasionally destructive to strawberry plants. The eggs are laid on the under side of the leaves and the nymphs remain there and suck the sap. The insect hibernates as eggs attached to the leaves, and these eggs hatch in early spring and the nymphs feed for about a month, pupate, and the tiny, mealy whiteflies appear to lay eggs for another brood. The number of generations each year is not known. The worst infestations are usually in patches, rather than over the whole field. In a small garden it is possible to under spray the leaves with nicotine sulfate and soap, but in a large field it can best be controlled by burning over the infested areas in the late fall.

White grubs, Phyllophaga sp. White grubs sometimes cause severe injury to strawberry fields by eating off the roots of the plants. Sod land should be avoided.

Injured areas should be plowed or disk-harrowed. See Corn.

\section{Sumac}

Aphids. At least two kinds of aphids occasionally infest sumac in Connecticut. Melaphis rhois forms a sac-like gall that projects downward from a leaflet. The opening is at the top and it is filled with immature 
aphids. Another aphid, Amphorophora rhois occurs on the under side of the leaves. Both these aphids infest the smooth sumac, Rhus glabra.

No information is available regarding control.

Mites, Eriophyes sp. The flower spikes of sumac are often injured by mites that curl the leaves and form a gall.

Little is known about this organism.

Sumac psyliids. Two kinds of psyllids or jumping plant lice are common on sumac. Calophya flavida infests the smooth sumac, and the immature nymphs which are dark gray or black with narrow white fringe may be found on the bark of the terminal twigs in winter. The adults have yellow transparent wings. Another species, Calophya nigripennis, with black opaque wings infests the shining sumac, Rhus copallina.

No control has been attempted.

\section{Sunflower}

Sunflower maggot, Straussia longipennis. The larvae of this fly frequently occur in considerable numbers inside the stalks of sunflower, weakening them so that they break over. The maggots feed next to the woody stem leaving a cylindrical core of pith detached. The fly has banded wings and belongs to the same group and feeds in about the same manner as the cherry fruit flies.

Possibly the adults may be poisoned by spraying the leaves with lead arsenate.

\section{Sweet Pea}

Aphids. The common aphid on sweet pea is the pea aphid, Illinoia pisi, but the potato aphid, Macrosiphum solanifolii, sometimes infests sweet pea. See Pea and Potato.

Celery or greenhouse leaf tier, Phlyctaenia rubigalis. This insect feeds upon sweet pea. See Celery.

Corn ear worm, Heliothis obsoleta. The larvae when abundant feed upon sweet pea and many other plants. See Corn.

\section{Sweet Potato}

Aphids. The potato aphid, Macrosiphum solanifolii, sometimes infests sweet potato. See Potato.

Blister beetles. Several species of blister beetles occasionally feed upon the leaves of sweet potato. See Aster.

Garden flea hopper, Halticus citri. This insect sometimes injures sweet potato. See Spearmint.

Tortoise beetles. Several species of tortoise beetles and their larvae feed upon sweet potato. These beetles are shaped like a tortoise shell or trench helmet with protruding edge. The more common species in Connecticut are: Chelymorpha cassidea, about three-eighths of an inch long, oval, yellowish or reddish brown with six small black spots on each wingcover; Deloyala clavata, about one-fourth of an inch long, with a roughened brown shield and very broad yellow semi-transparent flanges or margins; Chiridia guttata, less than one-fourth inch long, with smooth, glossy, black shield, some with yellow spots and yellow margins; Metriona bicolor, same size as preceding, reddish instead of black shield without markings, and yellow margins. All except the first are irridescent and changeable, and when alive and on the plant show as beautiful green and gold beetles. Unfortunately for our collections, these bright colors disappear when the insect dies.

The tortoise beetles are readily controlled by a spray of lead arsenate. 


\section{Sycamore}

Aphids. The large gray aphid, Longistigma caryae, is found on the bark and twigs of sycamore.

Sycamore lacebug, Corythucha ciliata. This lacebug is very common on the under side of the leaves of sycamore and on the upper surface the usual white-peppered effect indicates where this bug has sucked the sap. The adult bugs hibernate under the edges of the bark and other places where they can find protection. Soon after the leaves unfold, the bugs emerge and lay eggs on the under side of the leaves. The eggs hatch and the nymphs pass through five stages and become adults in a little more than a month. It is not known how many generations there are in a season.

The bugs can be killed by a spray of nicotine sulfate and soap.

Sycamore leaf folder, Ancylis platanana. The caterpillar of this little moth folds the leaf and feeds in the fold, chiefly along the midrib near the base of the leaf. The adult has a wing spread of about half an inch and is dull orange in color with darker, wavy bands.

Data are not available regarding control but probably a spray of lead arsenate would be effective.

White-marked tussock moth, Hemerocampa leucostigma. lars of this insect feed upon sycamore. See Horsechestnut.

The caterpil-

\section{Tobacco}

Aphids. Tobacco plants are not commonly or severely infested by aphids, although the potato aphid, Macrosiphum solanifolii, sometimes occurs upon the plants. See Potato.

Cranefly maggots. Tobacco is occasionally injured by cranefly maggots, Nephrotoma ferruginia, and possibly other species. The maggots are called "leather jackets" and they eat notches in the stems near the surface of the ground, causing some of the plants to break over, and all injured plants are ruined for crop production purposes. The maggots are about an inch long, gray, leathery in texture and have four protuberances on the head. The adults are two-winged flies with very long legs.

No remedy can be recommended.

Cutworms. Tobacco plants are often severely injured by cutworms soon after the plants are set in the field.

These plants are cut off near the ground, and the injury can be prevented by distributing poisoned bran mash over the field a few days before the plants are set. After the plants have grown to a height of 12 to 18 inches climbing cutworms sometimes devour portions of the leaves, and it is necessary to apply lead arsenate or put out more poisoned bait. See Tomato.

Garden springtail, Sminthurus hortensis. The garden springtail of ten injures young tobacco plants in the seed beds. See Beet.

Grasshoppers. Several species of grasshoppers feed upon the leaves of tobacco and the injury is usually more severe around the margins of the field. The species most commonly responsible for such injury are the Carolina grasshopper, Dissosteira carolina; the red-legged grasshopper, Melanoplus femur-rubrum; and the lesser migratory grasshopper, $M$. atlanis, but several other species may cause similar injury.

These grasshoppers may be controlled by distributing the bait of poisoned bran mash.

Greenhouse whitefly. Trialeurodes vaporariorum. This insect often infests tobacco in fields adjacent to a greenhouse or dwelling, where it can live through the winter. See Tomato.

Potato flea beetle, Epitrix cucumeris. This insect is responsible for nearly all the flea beetle injury to tobacco in Connecticut. See Potato. 
Seed corn maggot. The seed corn maggot, Hylemyia cilicrura, sometimes injures tobacco plants by entering the stems just below the surface of the ground. Sometimes only a pinhole is visible, but often a larger injury is apparent, and in certain instances there are several maggots inside the stalk perhaps hollowing it out. Such injury occurs on land where clover was grown the preceding year and turned under.

No control is known other than to avoid planting tobacco on clover sod. See Corn.

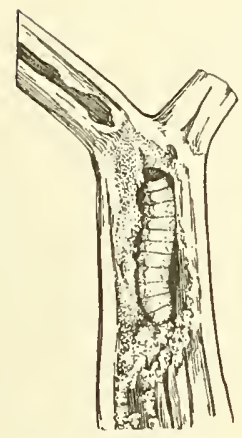

FIGURE 82.

Squash vine borer.

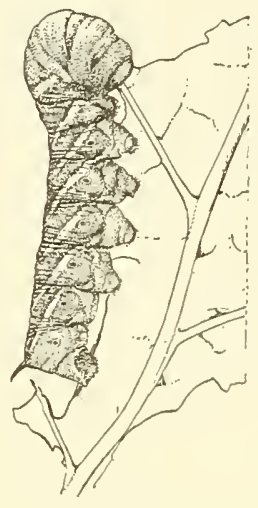

Figure 83.

Tobacco worm.

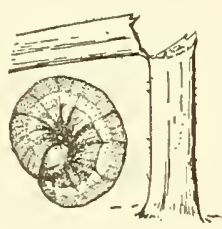

Figure 84. Cutworm.

Spined tobacco bug, Euschistus variolarius. This bug is only a minor pest of tobacco, but it sucks the sap from the leaves and tender tips causing them to wilt. Growers find that such injured leaves are of smaller size and of inferior quality. This bug is about half an inch in length, and varies in color from green to dark brown. It is one of the common Pentatomids or "stink bugs" and is found on many different kinds of plants.

Treatment is probably unnecessary.

Stalk borer, Papaipema nitela. The stalk borer is often a pest of tobacco. See Dahlia.

Tobacco horn worms. The tobacco worm, Phlegethontius quinquemaculata, is the more common horn worm in the tobacco fields of northern Hartford County, but the tomato worm, Phlegethontius sexta, is the more common in the region between Southington and New Haven. They cause identical injury and closely resemble each other, and the caterpillars of both devour the leaves of tobacco and tomato wherever these plants are grown throughout the state. The caterpillar reaches a length of about four inches, nearly as large as one's finger, usually green in color with whitish oblique bands along each side and with a sharp pointed horn on the back at the hind end. The insect hibernates in the ground as a naked brown pupa, about two inches long, with a tongue case bent down ward on one side. This tongue case or "jug-handle" is longer in the tobacco worm than in the tomato worm. The adult is one of the sphinx moths, also called hawk moths and humming-bird moths, that have large heavy bodies and long narrow wings. They fly at twilight and poise in the air to sip nectar from deep-throated flowers in the manner of a humming-bird. The wing spread is from four to five inches and the fore-wings are ash gray marked with many narrow, darker and lighter, wavy lines. The rear wings are whitish with 
dark gray outer margins, and are crossed by four black wavy or zigzag bands. The abdomen on each side has a row of large orange spots margined with black. The head, thorax and abdomen as seen from above are gray with black and white markings and the orange spots on the sides of the abdomen are also conspicuous. The moths appear in June and lay eggs singly on the leaves. The eggs hatch in from three to eight days and the caterpillars reach maturity in about a month. There is probably only one generation in Connecticut.

Control measures consist of destroying the caterpillars by hand, although spraying or dusting with lead arsenate is effective and is practiced in some tobacco growing regions. (Fig. 83.)

Wireworms. Wireworms are the larvae of "click beetles" of the family Elateridae. The adults are usually flat, elongated and narrow, black or brown, beetles. The larvae are yellow, orange or brown, hard, shiny and slender, and there are many different kinds that cause injury to plants. They have different life histories varying from two to six years for the complete life cycle. One of the more destructive species is the Eastern field wireworm, Pheletes ectypus, formerly Limonius agonus which in 1925 caused severe injury to several tobacco fields in Windsor.

Wireworms are difficult to control and are usually not known to be present until they have injured the plants. If the soil is known to be infested with wireworms, some large seeded crop like corn or beans may be planted early in every fifth row. The wireworms are attracted to the seeds and later work in the stems. A week or so before setting the tobacco plants, the rows of corn or beans should be treated by drilling into the soil close to the row of plants some "Cyanogas," a granular poison that gives off hydrocyanic acid gas. The poison should be covered with soil. The fumes will kill the wireworms and probably kill the plants, but the toxicity to plants disappears in a few days and it is then safe to set the tobacco.

\section{Tomato}

Aphids. The potato aphid, Macrosiphum solanifolii, and the spinach aphid, Myzus persicae, both commonly infest tomato plants.

A spray of nicotine sulfate and soap will control them. See Potato and Spinach.

Cutworms. There are perhaps 14 or 15 species of moths, the larvae of which are called cutworms. All belong to the family Noctuidae and are somber-colored moths. The larvae feed at night and coil up and rest during the day under rubbish or in the soil near the plant. Most of these cutworms reach a length of between one and two inches, are smooth, naked caterpillars, dull, gray, greenish or brownish in color, indistinctly marked with spots and longitudinal stripes. Some have one generation each year and others have two or more, but most of those that are troublesome in the field are probably of the single brood type that hibernate as partly grown larvae. When the field is plowed in spring these larvae that commonly feed on grass and weeds suddenly find their food supply destroyed. Few of them are able to travel across a large plowed field to find food. Consequently when the field is planted they take advantage of the new food supply and have their first square meal after a long fast.

In large fields and gardens it pays to distribute poisoned bran mash about the field at night a few days before the plants are set, or before the seedlings reach a size to supply them with food. If one has only a few plants, wrapping the stems with paper is a practical means of protection. (Fig. 84.)

Eelworms or nematodes, Heterodera radicicola. This minute eelworm infests the roots of plants causing knots or galls, especially in greenhouses. Tomato and cucumber are often injured. 
When an infested crop is removed, the soil should either be sterilized by steam or spread out in the field where it is subjected to freezing for at least one winter. (Fig. 85.)

Garden springtail, Sminthurus hortensis. This tiny insect often injures the young seedling tomato plants. See Beet.

Greenhouse whitefly, Trialeurodes vaporariorum. This whitefly commonly infests tomato plants under glass and is often carried into the field on the plants. The tiny moth-like adult has a mealy appearance due to the small particles of wax that it secretes. It lays eggs on the under side of a leaf. They are placed singly on end, but arranged in a circle containing from six to nine eggs. The eggs hatch in 11 days. The young move about for a short time then become stationary, begin to suck the sap, and resemble scale insects, being oval in shape with a marginal fringe of short wax rods. Whitish at first, when mature it turns yellow, the skin splits open along the back, and the adult emerges. About five weeks is the time required to complete the life cycle in the greenhouse. This insect infests many different kinds of plants.

As a control, greenhouses should be fumigated with hydrocyanic acid gas, using 1 ounce of cyanide for each 1,000 cubic feet of space. House and garden plants may be sprayed with nicotine and soap or pyrethrum-soap, directed against the under side of the leaves. (Fig. 86.)

Potato flea beetle, Epitrix cucumeris. This flea beetle is often very injurious to newly set tomato plants. See Potato.

Stalk borer, Papaipema nitela. The stalk borer often injures occasional tomato plants. See Dahlia.

Tomato worm, Phlegethontius sexta. The larva of this insect and the tobacco worm, $P$. quinquemaculata, often feed upon the leaves of tomato. When fully grown, this larva is about four inches in length, green, with oblique whitish bands along each side and a horn on the tail end of the body. The adult moth is similar to that of the tobacco worm except that the fore-wings have a more mottled gray brown appearance, and are somewhat darker in color. The wing spread is between four and five inches, and the tongue is coiled like a watch spring under the head.

Hand picking is the usual remedy, but spraying the plants with lead arsenate will prevent injury. See Tobacco.

\section{Trumpet Creeper}

Mealy flata, Ormenis septentrionalis. This insect sometimes occurs on trumpet creeper. See Lily.

\section{Tulip}

Aphids. The tulip aphid, Anuraphis tulipae, is perhaps the most common and most troublesome aphid on tulip, and is more apt to cause injury on forcing bulbs than out-of-doors. It also winters on stored gladiolus corms.

Soaking the bulbs or corms for half an hour in nicotine sulfate, 1 part in 800 parts water with soap, or in pyrethrum-soap, before setting will kill the aphids.

Bulb fly, Merodon equestris. This insect infests tulip. See Narcissus.

Garden millipede, Julus hortensis. These millipedes frequently attack the bulbs in tulip beds, especially in old beds where the bulbs are not reset each year. They eat into the bulbs and the mutilation is followed by decay. Sometimes all the bulbs are destroyed in this manner. When abundant, these millipedes also injure other bulbs, strawberry plants, and the roots of various other plants. Tulip bulbs may be dug after flowering, kept cool and dry, and planted in the fall. 
Some of the millipedes may be killed by the use of sliced potato or turnip dipped in lead arsenate or white arsenic and water and distributed throughout the field or bed.

\section{Tulip Tree}

Aphid. Only one species of aphid, Macrosiphum liriodendri, seems to be common on tulip tree. These are rather small green aphids that occur on the under side of the leaves.

A spray of nicotine sulfate and soap will kill them.

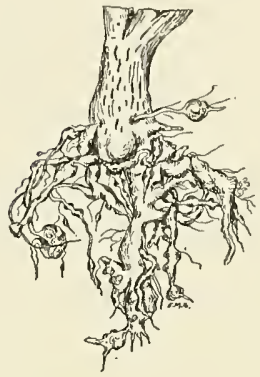

Figure 85. Root knot caused by eelworm.

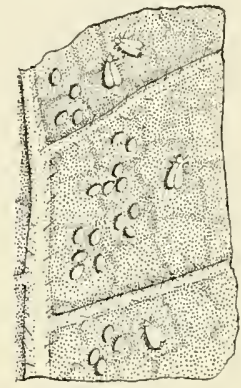

FIGURE 86. Greenhouse whitefly.

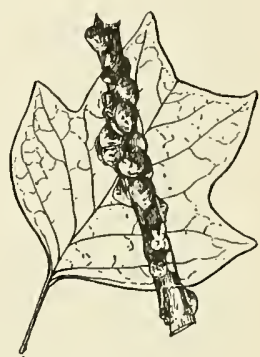

FIGURE 87 Tulip tree scale.

Tulip tree scale, Toumeyella liriodendri. This is a large brown hemispherical soft scale that infests the branches of the tulip tree. This description applies to the females which reach a diameter of nearly one-third of an inch, but the males are small, flat, gray scales that are much less conspicuous. There is one generation each year and the young appear in September, crawl about for a time, then fix themselves to the bark and suck the sap. They are less than one-fourth grown when winter arrives, and the best treatment is to spray the dormant trees in early spring with either miscible oil or lime-sulfur. (Fig. 87.)

Tulip tree spot gall, Thecodiplosis liriodendri. This gall shows from both sides of the leaves and is a circular brown spot surrounded by a circle of yellow or light green. Sometimes badly infested leaves will drop, but otherwise it is not serious and no method of control is known.

\section{Turnip}

Aphids. The most important aphid infesting turnip is the turnip aphid, Aphis pseudobrassicae. It often ruins fields of turnips, especially rutabagas, so that the crop has to be plowed under. Other aphids that sometimes infest turnip are the spinach aphid, Myzus persicae, and the potato aphid, Macrosiphum solanifolii.

Dusting the plants under a trailing cloth cover, using nicotine dust, is perhaps the best form of control. If the leaves stand upright a nicotine sulfate and soap spray may be applied.

Cabbage maggot, IIylemyia brassicae. This insect often injures turnip. See Cabbage.

Other insects. Most of the insects infesting cabbage will occasionally feed upon turnip. See Cabbage. 


\section{Verbena}

Aphids. The spinach aphid, Myzus persicae, sometimes infests verbena. The remedy is to spray with nicotine sulfate and soap or with pyrethrumsoap.

Verbena budworm, Olethreutes hebesana. The larva of this insect is a borer in the new shoots of verbena and Physostegia, causing them to wither. The larva is greenish yellow with black head and is a little less than half an inch in length when mature. The adult is a purplish brown moth with wing spread of half an inch. No treatment can be recommended other than clipping off and burning the infested tips.

Yellow woolly bear, Diacrisia virginica. Whitish, yellowish or brownish hairy caterpillars feed upon the leaves of verbena and many other kinds of plants in the garden in late summer. This caterpillar is about two inches in length when fully grown and is covered with long hairs that vary in color from pale yellow to reddish brown. It makes its cocoon of its own hairy coat and silk, under rubbish and in other sheltered places, sometimes 20 to 30 being clustered together. In this stage the insect hibernates and the moths emerge in June and July. The moth has a wing spread of between one and one-half and two inches, and is pure white with a few black dots, blackish antennae, abdomen orange with a row of black spots on the back and along each side.

Hand picking is the usual means of control, but the plants may be protected by spraying with lead arsenate.

\section{Violet}

Aphids. The violet aphid, Myzus violae, and probably also the spinach aphid, Myzus persicae, occasionally infest violet plants.

Control may be obtained by dusting with nicotine dust or spraying with nicotine sulfate and soap, or with pyrethrum-soap.

Eelworms. Eelworms often infest the roots of violet. See Tomato.

Garden slugs. Garden slugs often feed upon the leaves of violet. See Lettuce.

Violet gall midge, Phytophaga violicola. The small two-winged fly or midge lays white eggs in the curled margins of the unfolded new leaves. These eggs hatch and the maggots remain in the curled margins causing a greater curling and distortion and twisting of leaves.

There are probably several generations annually in greenhouses, and the best treatment seems to be to fumigate the greenhouse occasionally, using one ounce of cyanide for each 1,000 cubic feet for a period of two hours. The house should not be left closed over night.

Violet sawfly, Emphytina canadensis. The leaves of violet plants in the garden are often eaten at night by blue-black larvae with whitish tubercles. These larvae hide under the lower leaves or in the soil during the day, and when full grown are about half an inch in length. The adult is a black four-winged fly or sawfly about five-eighths of an inch long that lays eggs in blister-like incisions in the leaves. There is only one brood each year.

This insect may be controlled by spraying or dusting the plants with hellebore or lead arsenate.

Yellow woolly bear, Diacrisia virginica. The caterpillars sometimes feed upon violet. See Verbena.

\section{Virginia Creeper}

Eight-spotted forester, Alypia octomaculata. Caterpillars cross-banded with black, white and orange feed upon the foliage of Virginia creeper, sometimes stripping the vines. The adult is a black moth with wing- 
spread of from one and one-fourth to one and one-half inches, with two pale yellow spots on each fore-wing and two white spots on each rear wing. The insect winters as a pupa in the soil, and there is only one generation each year in Connecticut.

Hand picking is the only control needed, except occasionally when the insect is very abundant, in which case a spray of lead arsenate will prove effective.

Leafhoppers, Erythroneura vulnerata. This and probably other species infest the leaves of Virginia creeper. Control measures are needed only when the leafhoppers are exceedingly abundant, and a spray of nicotine sulfate and soap directed against the under sides of the leaves is perhaps the best treatment.

Sphinx caterpillars. See Grape.

Woodbine vein gall, Dasyneura parthenocissi. This gall is somewhat irregular in shape and occurs on the under side of the leaf along the midvein.

Control measures are unknown and unnecessary.

\section{Walnut}

Aphids. The large gray aphid, Longistigma caryae, is found on Japanese walnut. The black walnut is infested by the three following hickory aphids, Monellia caryae, $M$. caryella and $M$. costalis.

Spraying with nicotine sulfate and soap is the remedy.

Oyster-shell scale, Lepidosaphes ulmi. The oyster-shell scale often infests walnut. See Apple.

Walnut bud moth, Acrobasis caryae. The caterpillars of this moth feed upon the tender terminal leaves and shoots, webbing them together, and injure and distort the new growth or stop it entirely. The full-grown larva is about five-eighths of an inch in length, and of a dirty olive green color with shining black head. The adult moth has a wing spread of about threefourths of an inch and is gray in color with lighter areas at the base of the fore-wings.

This insect is readily controlled by a lead arsenate spray such as is used against the walnut weevil.

Walnut caterpillar, Datana integerrima. This caterpillar is usually noticed in August when clusters of black caterpillars with whitish hairs are found stripping the branches of walnut and hickory. On the trunks and larger branches may be seen gray hairy patches where the flock of caterpillars have molted or cast their skins. The mature caterpillars are about two inches in length, black, and covered with whitish hairs. The adult moth has a wing spread of about two inches, is light reddish brown in color, the fore-wing crossed by darker reddish lines, and with a bright mahogany red spot on the thorax. The moths emerge in July and lay clusters of eggs on the under side of the leaves. The caterpillars become mature in September, pupate in the ground and remain there until the moths emerge the following season. There is only one generation each season.

Control consists of spraying the foliage with lead arsenate about August 1 , or, on small trees the caterpillars may be gathered and crushed.

Walnut scale, Aspidiotus juglans-regiae. The Persian walnut and the Japanese walnut are sometimes infested by this circular light gray scale that is about one-eighth inch in diameter. Its life history is similar to that of the San José scale, and it may be controlled by a dormant spray of lime-sulfur or miscible oil.

Walnut weevil, Conotrachelus juglandis. This insect breeds in the nuts and new shoots of walnut, and often severely injures Persian and Japanese varieties. The adult is a snout beetle, about one-fourth of an inch long, 
brownish gray in color, with a broad whitish band across the wing-covers just beyond the center. The beetles hibernate in protected places and appear on the trees the latter half of May and eat holes into the shoots and leaf stems. The females lay eggs in both the fruit and stems under flaps in crescent-shaped punctures like the plum curculio. The young larvae tunnel in the new shoots, at the base of the leaf stems, and some go into the fruit. They mature in four to six weeks, then enter the ground where they pupate about an inch beneath the surface and from 16 to 20 days later the adults emerge. The beetles do some feeding, then early in September seek their winter quarters. There is one annual generation. This insect may be controlled by thoroughly spraying the new shoots and leaves with lead arsenate in early June, using 1 pound of the poison in 10 gallons of water. See Report of this Station for 1912, p. 240.

\section{Watercress}

Diamond-back moth, Plutella maculipennis. The larvae of this moth feed upon watercress. See Cabbage.

Spinach aphid, Myzus persicae. The spinach aphid sometimes infests watercress. See spinach.

Watercress leaf beetle, Phaedon aeruginosa. This is a small bronzeblack beetle about an eighth of an inch in length. The full-grown larva is about one-fifth of an inch long, and brownish black with numerous tubercles bearing hairs. Both adults and larvae feed upon the under side of the leaves of watercress. No satisfactory control has been devised.

Watercress sowbug, Mancasellus brachyurus. This is a gray shrimplike sowbug, about half an inch in length, that eats off the roots and submerged stems of watercress, causing large masses to float upon the surface of the water.

In natural streams and ponds there is no satisfactory control. In artificial pools where the water can be drawn off, the sowbugs can be concentrated in a trough at the bottom and later killed by the application of copper sulfate.

\section{Water Lily}

Aphids. The corn leaf aphid, Aphis maidis, and the water lily aphid, Rophalosiphum nymphaeae, both infest the leaves of water lily.

Leaf beetles. At least three different kinds of beetles feed upon the leaves of water lily. These are, Donacia palmata and D. piscatrix, both metallic bluish or brownish beetles each about three-eighths of an inch in length. The third is a dull brownish beetle, Galerucella nymphaeae.

Possibly dusting the leaves with lead arsenate would prevent injury in ornamental pools.

\section{Watermelon}

Melon aphid. The melon aphid, Aphis gossypii, sometimes infests watermelon. See Melon.

Melon worm and pickle worm. The melon worm, Diaphania hyalinata and the pickle worm, $D$. nitidalis, rarely infest watermelon in the southern states. See Melon and Cucumber.

Squash ladybeetle, Epilachna borealis. The squash ladybeetle occasionally feeds upon the leaves of watermelon. See Squash. 


\section{Weigela}

Four-lined plant bug, Poecilocapsus lineatus. The bugs often injure the tender terminal leaves of weigela. See Currant.
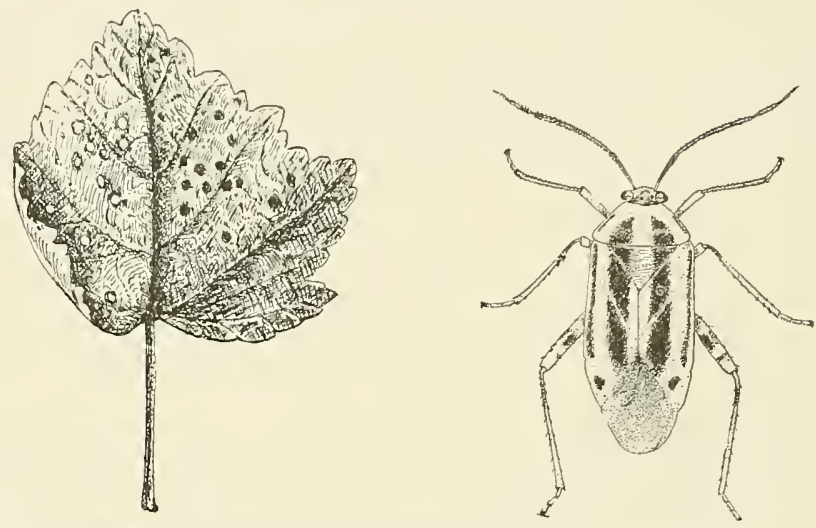

FIGURE 88. Four-lined plant bug and leaf injured by it.

\section{Wheat}

Aphids. Wheat is sometimes infested by Toxoptera graminum, Macrosiphum granarium, and probably by Rophalosiphum prunifoliae and the spinach aphid, Myzus persicae. In case of a severe infestation, cutting the grain for fodder is the only remedy.

Armyworm, Cirphis unipuncta. The armyworm feeds upon the leaves and stems of wheat. See Grass.

Hessian fly, Phytophaga destructor. This insect is never conspicuous, but is usually behind the sheaths of the lower leaves, as white or greenish white shiny maggots or puparia that resemble flax seeds. The winter is passed by the larvae in the flaxseed stage. There are usually two generations each year. Infested stems are usually unable to support the heads of grain and break over. Heavily infested fields may have 50 to 75 per cent of the stems broken and the yield is seriously reduced.

The only practicable control measures are seeding late in the fall so that the wheat will not come up until after the flies have emerged, laid their eggs and died, and plowing under the infested stubble soon after harvesting the crop.

Wheat midge, Thecodiplosis mosellana. This insect infests the heads and causes shrunken kernels. Small orange-yellow maggots are present around the bracts and sometimes give an orange color to the heads. The best control is to plow under the stubble and burn the litter after threshing.

\section{Willow}

Aphids. There are several species of aphids that infest the willows. One of the commonest is Melanoxantherium smithiae. The purplish aphids are present on the small twigs in the fall, and eggs are laid to carry the species through the winter. Another species, Chaitophorus nigrae, has also been recorded on willow from Connecticut. 
These aphids may be controlled by spraying with nicotine sulfate and soap.

Fall webworm, Hyphantria cunea. The fall webworm feeds upon willow. See Pear.

Gipsy moth, Porthetria dispar. The caterpillars of the gipsy moth feed upon willow. See Apple.

Imported willow leaf beetle, Plagiodera versicolora. Dark metallic blue, shiny beetles, an eighth of an inch in length and their larvae feed upon the leaves of willow, especially the glossy leaf varieties. The adult beetles hibernate under bark and in other sheltered places and emerge in April and May and the females lay yellow eggs in clusters on the under side of the leaves. These eggs hatch in four or five days and the grubs feed on the leaves, eating away the lower tissue and leaving only the veins and upper epidermis. The grubs are bluish black, alligator-like larvae that skeletonize the foliage but the beetles may eat holes through the leaves. There are two generations each season.

The treatment is to spray with lead arsenate.

Mite galls, Eriophyes sp. These are very common on willow, but little is known about them. Possibly a dormant spray of miscible oil may control them.

Oyster-shell scale, Lepidosaphes ulmi. The oyster-shell scale commonly infests willow. See Apple.

Poplar and willow curculio, Cryptorhynchus lapathi. This insect is a borer in willow and has killed many fine specimens of pussy willow during the past few years. See Poplar.

Poplar leaf beetles, Lina scripta and L. lapponica. These beetles often feed upon willows, especially basket willows. See Poplar.

Poplar tent-maker, Melalopha inclusa. This insect also feeds upon willow. See Poplar.

Satin moth, Stilpnotia salicis. The caterpillars of this insect feed also upon willows. See Poplar.

Spiny elm caterpillar, Euvanessa antiopa. The caterpillars feed on willows. See E1m.

Willow cone gall, Rhabdophaga strobiloides. This is a gray or brown cone-shaped gall about an inch long on the tips of willow shoots. The egg is laid by a small two-winged fly or midge in early May and the gall reaches maturity in June. There is evidently one brood each year.

No control is recommended.

Willow sawflies. Several species of sawflies infest willow, but only two can be mentioned here. The currant stem girdler, Janus abbreviatus, is a wasp-like insect about half an inch long that appears in early spring and lays eggs in the new shoots of willow, and then girdles the stem below the egg. The larvae are borers in the shoots, sometimes tunneling them for two feet, and reach maturity in November, and transform in the shoots. Cutting and burning the wilted shoots will control this insect. The yellowspotted willow slug, Pteronus ventralis, is a greenish black sawfly larva, about half an inch in length, that feeds upon willow and poplar. There is a row of yellow spots along each side.

This insect often severely injures basket willows, but may be controlled by a spray of lead arsenate.

\section{Wistaria}

Mealy flatas, Ormenis pruinosa and O. septentrionalis. These insects are often faund on wistaria. See Lily.

Silver-spotted skipper, Epargyreus tityrus. The caterpillars feed upon the leaves of wistaria. See Locust. 


\section{Yew}

Black vine weevil, Brachyrhinus sulcatus. The larvae of this snout beetle often injure Taxus plants in nurseries and ornamental plantings by feeding on the roots. The grubs devour the small roots and gnaw the bark from the larger roots, of ten girdling them. The tops first turn yellow and later brown and the severely injured plants die. The adult is a snout beetle nearly half an inch in length, dark brown or black in color, marked with scattered spots of light brown pubescence. The grub is dirty white with dark head, without legs and is curved after the manner of the grubs of weevils or curculios.

The plants may be protected by applying lead arsenate to the soil.

\section{Zinnia}

Stalk borer, Papaipema nitela. The stalk borer often infests zinnia. See Dahlia.

\section{FORMULAS FOR INSECTICIDES}

\section{Stomach Poisons}

\section{Calcium arsenate}

Calcium arsenate $3 \mathrm{lbs}$ Hydrated lime $3 \mathrm{lbs}$.

\section{Water 100 gals.}

Applied as a spray on vegetables. May be used in Bordeaux mixture. Not safe on fruit trees.

Calcium arsenate $1 \mathrm{lb}$.

Gypsum 15 lbs.

Apply as a dust for cucumber beetles on cucumbers and squashes.

\section{Lead arsenate}

Lead arsenate $3 \mathrm{lbs}$.

Water 100 gals.

Spray on foliage to kill chewing insects. May be used with Bordeaux or with lime-sulfur mixture.

\section{Coated lead arsenate}

Coated lead arsenate 8 lbs. Water 100 gals.

Use as a spray to kill Japanese beetles feeding on foliage of ornamenta 1 plants.

\section{Magnesium arsenate}

Magnesium arsenate 3 lbs. Calcium caseinate 2 lbs.

Water 100 gals.

Apply as a spray for Mexican bean beetle.

Magnesium arsenate $11 \mathrm{~b}$.

Hydrated lime 5 lbs.

Apply as a dust for Mexican bean beetle. 


\section{Barium fluosilicate}

Barium fluosilicate $1 \mathrm{lb}$. Hydrated lime $5 \mathrm{lbs}$.

Use as a dust for Mexican bean beetle.

\section{Paris green}

$$
\begin{gathered}
\text { Paris green } 1 \mathrm{lb} \text {. Lime } 3 \text { lbs. } \\
\text { Water } 100 \text { gals. }
\end{gathered}
$$

Spray on vegetables to kill chewing insects. Formerly used with Bordeaux mixture on potatoes, but now largely superseded by lead or calcium arsenate.

\section{Fresh hellebore}

Dust on plants, or mix with water, $1 \mathrm{oz}$. in 2 gals., and spray. For currant worm and other sawfly larvae.

\section{Dust Mixtures}

Sulfur $85 \%$, lead arsenate $15 \%$ (or sulfur $90 \%$, lead arsenate $10 \%$ ) is used to dust apple orchards for fungous diseases and chewing insects. To kill sucking insects add $5 \%$ of $40 \%$ nicotine sulfate. Monohydrated copper sulfate $15 \%$ to $25 \%$, hydrated lime $80 \%$, and calcium arsenate $5 \%$ to $25 \%$, is used successfully on vegetables, but is likely to russet apples. Plain sulfur is used in peach orchards. These dusts can be purchased mixed ready for use.

\section{Calomel-gypsum dust}

$$
\text { Calomel } 4 \text { oz. Gypsum } 6 \text { lbs. }
$$

Apply as a dust on the soil around cabbage plants to prevent injury from cabbage root maggot.

\section{Corrosive sublimate}

$$
\text { Corrosive sublimate } 1 \mathrm{oz} \text { Water } 10 \text { gals. }
$$

Pour $1 / 2$ teacupful around each cabbage plant to prevent injury from cabbage root maggot.

\section{Ant poisons}

\section{Poison Baits}

Arsenate of soda 125 grains.

Honey 1 tablespoonful.
Sugar 1 lb.

Water 1 qt.

Add arsenate of soda and sugar to water. Boil until both are dissolved, then add honey. When cool, place in shallow dishes with a crust of bread or bits of sponge.

Tartar emetic 1 teaspoonful.

Corn syrup 1 teaspoonful.

Mix as a bait for ants. If ants are feeding on fats, use bacon or ham grease instead of corn syrup. Place bait in shallow dishes.

\section{Poisoned bran mash}

Wheat bran 5 lbs.

White arsenic or Paris green $4 \mathrm{oz}$.

$$
\begin{gathered}
\text { Cheap molasses } 1 \text { pint. Water } 7 \text { pints. } \\
1 \text { Lemon }
\end{gathered}
$$

Mix to form a dry mash and scatter around field to kill cutworms, armyworms and grasshoppers. 


\section{Formalin fly poison}

Commercial formalin 1 tablespoonful. Sweet milk $1 / 2$ cup. Water $1 / 2$ cup.

Mix and expose in a shallow plate with a slice of bread in it. Flies will drink the liquid, especially if no other moisture is accessible, and be killed.

\section{Nicotine solution}

\section{Contact Insecticides}

$40 \%$ nicotine sulfate solution 1 pint.

Water 100 gals.

Excellent for killing aphids and other sucking insects. Omit soap if used with lead arsenate.

\section{Pyrethrum-soap sprays}

Use pyrethrum-soap sprays to kill sucking insects on greenhouse, ornamental or vegetable plants. Follow manufacturer's directions for diluting. These sprays are non-poisonous to man and do not stain flowers.

\section{Glue solution}

Cheap powdered glue $1 \mathrm{lb}$. Water 10 gals.

Dissolve glue in 1 gal. boiling water and dilute to 10 gals. Used for mites on evergreens.

\section{Linseed oil emulsion}

Raw linseed oil 1 gal. Soap flakes $1 \frac{1}{2} 1 \mathrm{bs}$. Water 1 gal.

Dissolve flakes in water; stir in linseed oil, and dilute to 100 gals. Used for mites on evergreens.

\section{Miscible oils}

Mix 1 gal. of miscible oil with 20 or 25 gals. water to kill San José scale and eggs of European red mite. Apply before growth starts in the spring. Common miscible oils are: Scalecide, Sunoco Spray Oil, Dendrol, Scale-O, Victor Soluble Oil, and Target Scale Destroyer.

\section{Oil emulsions}

Mix 1 gal. Kleenup, Emulso, or other dormant oil emulsions with 20 gals. of water to kill San José scale and eggs of the European red mite. For summer or greenhouse sprays use Volck, Verdol, or other summer oil emulsions, 1 or 2 gals, in 100 gals. water to kill mites and scale insects on ornamental plants and scale insects, mealybugs, and other sucking insects on greenhouse plants.

\section{Common laundry soap}

Spray 1 lb. common laundry soap dissolved in 8 gals. water to kill red spider, aphids and other sucking insects. One-half lb. soap flakes may be used in 8 gals. water. Do not use with lead arsenate. 


\section{Lime sulfur}

$\begin{array}{llrr} & & \text { Dry } & \text { Liquid } \\ \text { Summer spray } & \text { Lime-sulfur } & 6 \mathrm{lbs} . & 3 \text { gals. } \\ & \text { Water } & 100 \text { gals. } & 100 \text { gals. } \\ \text { Winter spray } & \text { Lime-sulfur } & 24 \text { lbs. } & 1 \text { gal. } \\ & \text { Water } & 100 \text { gals. } & 9 \text { gals. }\end{array}$

Use winter spray for San José scale and peach leaf curl; summer spray for fungi, to which, as needed, add lead arsenate to kill chewing insects.

\section{Carbon disulfide}

\section{Fumigants}

To kill insects infesting stored grain, in tight bins, use $1 \mathrm{lb}$. for each 100 cubic feet of space. Expose for about 36 hours at $60^{\circ} \mathrm{F}$. or higher. The gas is inflammable and fire or sparks must be kept away.

\section{Carbon disulfide emulsion}

Carbon disulfide 10 gals. Rosin fish oil soap 1 gal.

Water 3 gals.

Possibly a commercial preparation may be found more satisfactory.

Churn the soap and water to obtain an even mixture. Then add carbon disulfide and churn about two minutes until the mixture emulsifies, as indicated by change in color, and a creamy liquid is formed. Dilute 200 times when using and apply 1 quart to the square foot, to kill insects in soil without injuring vegetation.

\section{Paradichlorobenzene}

A granular solid chemical which gives off a gas fatal to insect life, used successfully to control the peach borer. Also effective as a fumigant for clothes moths. Called Krystal gas, Paradichloride, P. C. Benzene, and Dichloricide.

\section{Naphthalene}

Used in the form of moth balls and flakes to keep clothes moths out of clothing. Flakes scattered around the borders of floors and shelves will drive away ants. Also useful as a fumigant to kill fleas in houses.

Recently naphthalene fumigation of greenhouses has been successful in controlling red spider on carnations and mites on cyclamen. The naphthalene should be volatilized very slowly by means of a lamp or electric hot plate, at the rate of $1.5 \mathrm{oz}$. to $1000 \mathrm{cubic}$ feet of greenhouse space. The temperature should be maintained at $70^{\circ} \mathrm{F}$, and the relative humidity at $80 \%$, and the fumigation must be done at night. Some species of plants are susceptible to injury from naphthalene vapor.

\section{Hydrocyanic acid gas}

Sodium cyanide $1 \mathrm{oz}$ Sulfuric acid 2 fluid ozs.

Water 4 fluid ozs. for each $100 \mathrm{cu}$. ft. space.

For fumigating dormant nursery stock or buildings place the acid and water in an earthen jar in the house, drop in the cyanide, and close the house at once for half an hour. Ventilate for ten minutes before entering. In greenhouses use $1 \mathrm{oz}$. of cyanide for each $1000 \mathrm{cu}$.ft. of space; avoid sunlight, excessive moisture, driving winds. Fumigate between $52^{\circ}$ and $70^{\circ} \mathrm{F}$. 
Calcium cyanide in granular form may now be obtained for fumigation or killing grubs, wireworms and ants in soil; and in form of dust for fumigating to kill aphids and other sucking insects. For greenhouse fumigation, use one-fourth ounce for each 1,000 cubic feet of space.

Caution: Breathing the fumes will cause death.

\section{Spreaders and Stickers}

\section{Calcium caseinate spreaders}

1-2 lbs. in 100 gals. acts as a spreader and prevents chemical reactions when different materials are mixed together.

\section{Soap spreaders}

Use dry soap at the rate of 4 lbs. to 100 gallons nicotine solution to increase wetting and spreading. Use $5 \mathrm{lbs}$. fish oil soap or $7 \mathrm{lbs}$. liquid soap. Do not use in combination with lead arsenate.

\section{Fish oil sticker}

Use 1 pint fish oil to $3 \mathrm{lbs}$. lead arsenate in 100 gallons of water in early summer sprays to control the gipsy moth on shade trees. A special formula recommended for the control of the plum curculio is as follows: Lime, 10 lbs., fish oil, 1 qt., lead arsenate, 3 lbs., water, 100 gals.

Dilution Table For Insecticides

\begin{tabular}{|c|c|c|c|c|}
\hline \multirow{2}{*}{ Material } & \multicolumn{4}{|c|}{ Amounts needed to make } \\
\hline & 100 gallons & 50 gallons & 5 gallons & 1 gallon \\
\hline $\begin{array}{l}\text { Arsenate of lead } \\
\text { Coated arsenate of lead } \\
\text { Calcium arsenate } \\
\text { Magnesium arsenate } \\
\text { Calcium caseinate spreader } \\
\text { Nicotine sulfate } 1-800 \\
\text { " } 1-400 \\
\text { Soap spreader (with nicotine } \\
\text { sulfate only) } \\
\text { Miscible oil } 1-20 \\
\text { Oil emulsion (winter) } 1-20 \\
\text { " } \quad \text { (summer) } 1 \% \\
\text { " } \quad 2 \%\end{array}$ & $\begin{array}{l}3 \text { lbs. } \\
8 \text { " } \\
3 \text { " } \\
3 \text { " } \\
1 \text { " } \\
1 \text { pint } \\
1 \text { qt. } \\
4 \text { lbs. } \\
5 \text { gals. } \\
4 \text { " } \\
5 \text { " } \\
1 \text { " } \\
2 \text { " }\end{array}$ & 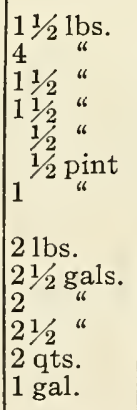 & $\begin{array}{l}21 / 2 \text { oz. } \\
61 / 2 \text { " } \\
21 / 2 \text { " } \\
21 / 2 \text { " } \\
1 \\
11 / 2 \text { tblsp. } \\
3 \\
3.2 \mathrm{oz} . \\
1 \text { qt. } \\
11 / 2 \text { pints } \\
1 \text { qt. } \\
61 / 2 \text { fluid oz. } \\
14 \text { " }\end{array}$ & 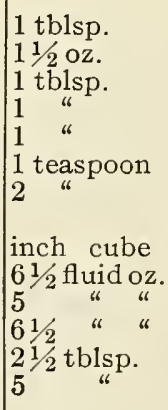 \\
\hline
\end{tabular}

Equivalent Weights and Measures

4 teaspoons $=1$ tablespoon

2 tablespoons $=1$ fluid ounce

16 fl. ozs. = 1 pint 8 pints $=1$ gallon 


\section{INDEX TO INSECT PESTS}

Citations cover all scientific names and accepted common names and refer to the principal descriptions only. Plant hosts and cross references are not included.

Abia americana, 119

$$
\text { inflata, } 119
$$

Acanthoscelides obtectus, 82

Acidia fratria, 137

Acrobasis caryae, 174

Acrosternum hilaris, 83

Adelges abietis, 162

pinicorticis, 145

strobilabius, 122

Aegeria exitiosa, 139

Agallia sanguinolenta, 97

Agrilus anxius, 85

bilineatus, 95

communis ab. rubicola, 159

ruficollis, 87

sinuatus, 143

Agriolimax agrestis, 124

Agromyza clara, 92

melampyga, 131

parvicornis, 100

platyptera var. coronata, 81

posticata, 81

pusilla, 132

simplex, 79

Alcathoe caudata, 96

Aleyrodes azaleae, 81

Alsophila pometaria, 72

Alypia octomaculata, 173

Ampelophaga myron, 114

Amphibolips confluens, 133

Amphorophora lactucae, 124 rhois, 167

Anaphothrips striatus, 99

Anarsia lineatella, 139

Anasa tristis, 164

Ancylis comptana, 166

platanana, 168

Andricus clavula, 134

punctatus, 134

seminator, 134

Anisota rubicunda, 128 senatoria, 134

Anoecia querci, 114, 132

Anomala orientalis, 122

Anthomyia radicum, 154

Anthonomus signatus, 166

Ants, 122

Anuraphis crataegifoliae, 115 maidi-radicis, 98

roseus, 77

tulipae, 171

riburnicola, 160
Aphis davisi, 148

forbesi, 165

gossypii, 104, 144

laburni, 126

maidis, 98

monardae, 83

persicae-niger, 138

pomi, 75

pseudobrassicae, 172

rubicola, 154

rufomaculata, 96

rumicis, 82

saliceti, 137

sanborni, 103

spiraecola, 86

symphoricarpi, 160

viburniphila, 160

Aphrophora parallela, 146

Apple and thorn skeletonizer, 71 maggot or railroad worm, 72

Arborvitae leaf miner, 79 soft scale, 79

Archips argyrospila, 75 cerasivorana, 95 rosana, 158

Argyresthia thuiella, 79

Armyworm, 114

Aserica castanea, 123

Ash flower gall, 79 sawfly, 79

Asiatic beetle, 122 garden beetle, 123

Asparagus miner, 79

Aspidiotus abietis, 116

hederae, 135

juglans-regiae, 174

perniciosus, 143

uvae, 113

Asterolecanium variolosum, 134

Asynonychus godmani, 156

Aulacaspis pentagona, 140 rosae, 158

Autographa brassicae, 89

Azalea bark scale, 81 whitefly, 81

Balaninus obtusus, 116

Barberry aphid, 81 webworm, 82 
Bean aphid, 82

leaf beetle, 82

leafhopper, 82

weevil, 82

Bedellia somulentella, 131

Beech woolly aphid, 84

Bembecia marginata, 155

Birch leaf skeletonizer, 85 sawfly, 85

Blackberry knot gall, 104 leaf miner, 87 psyllid, 87 sawfly, 87

Black cherry aphid, 94

Black-headed cranberry worm or fireworm, 100

Black vine weevil, 178

Blissus leucopterus, 123

Blister beetles, 80

Blueberry flea beetle, 88 gall, 88 spittlebug, 88

Box leaf miner, 88 psyllids, 88

Brachyrhinus ovatus, 165 sulcatus, 178

Brevicoryne brassicae, 89

Broad-necked prionus, 133

Bronze birch borer, 85

Brown-tail moth, 140

Bruchus pisorum, 137

Bryobia praetiosa, 97

Bucculatrix canadensisella, 85 pomifoliella, 75

Bud moth, 72

Bulb fly, 132 mite, 132

Byturus unicolor, 154

Cabbage aphid, 89 looper, 89 maggot, 89 worm, 90

Cacoccia rosaceana, 158

Cactus scale, 91

Calaphis castancae, 95

Caliroa aethiops, 158

Calophya flavida, 167 nigripennis, 167

Camellia scale, 91

Canker worms, 72

Carpenter worm, 126

Carpocapsa pomonclla, 73

Carrot rust fly, 92

Caryomyia caryae, 118

caryaecola, 118

holotricha, 118

persicoides, 118

tubicola, 118

Cigar case bearer, 72
Catalpa leaf miner, 92 mealybug, 92

Cecidomyia ocellaris, 128

Celery or greenhouse leaf tier, 93 worm, 93

Cerodonta femoralis, 99

Cerotoma trifurcata, 82

Chaitophorus nigrae, 176 viminalis, 148

Chalepus dorsalis, 126

Chelymorpha cassidea, 167

Cherry maggots or fruit flies, 94 slug or pear slug, 94 tree tortrix, 95

Chinch bug, 123

Chionaspis americana, 106 enonymi, 108 furfura, 143 pinifoliae, 146

Chirida guttata, 167

Chrysobothris femorata, 74

Chrysomela elegans, 98

Chrysomphalus aonidum, 159 dictyospermi, 159

Circular scale, 159

Cirphis unipuncta, 114

Citheronia regalis, 117

Cladins isomerns, 158

Clastoptera proteus, 88

Clematis borer, 96

Clover bud weevil, 97 -head caterpillar, 97 leafhopper, 97 leaf weevil, 97 mite, 97

Coccus hesperidum, 109, 136

Codling moth, 73

Coleophora fletcherclla, 72 laricella, 122 malivorella, 72

Colorado potato beetle, 150

Columbine borer, 97 leaf miners, 98

Common asparagus beetle, 80

Conotrachelus cratacgi, 143, 153 juglandis, 174 nenuphar, 73, 147

Contarinia pyrivora, 141

Coptodisca splendoriferclla, 153

Corn ear worm, 99 root webworm, 99

Corythucha ciliata, 168 cydoniae, 115

Cottony maple scale, 127

Crambus caliginosellus, 99 praefectellus, 99

Cranberry fruit worm, 101

Cranefly maggots, 168 
Crioceris asparagi, 80 duodecimpunctata, 80

Croesus latitarsus, 85

Cryptorhynchus lapathi, 148

Curculio, apple, 73 plum, 73 quince, 143, 153 rhubarb, 156

Currant aphid, 102 borer, 102 fruit fly, 102 stem girdler, 102

Cutworms, 136, 170

Cyclamen mite, 104

Cyllene caryae, 118 robiniae, 126

Cymatophora ribearia, 111

Dasyneura communis, 128 parthenocissi, 174 rhodophaga, 158

Datana integerrima, 174 ministra, 78

Deloyala clavata, 167

Deltocephalus inimicus, 114

Dendothrips ornatus, 152

Dendroctonus piceaperda, 162 terebrans, 145 valens, 145

Depressaria heracliana, 137

Diabrotica duodecimpunctata, 101 vittata, 101

Diacrisia virginica, 173

Diamond-back moth, 90

Diaphania hyalinata, 130 nitidalis, 101

Diapheromera femorata, 134

Diarthronomyia hypogaca, 96

Diaspis carueli, 93 echinocacti cacti, 91

Diastrophus nebulosus, 104

Dichomeris ligulclla, 76 marginelliss, 121

Dilachnus pinicola, 144 strobi, 144

Diprion simile, 146

Disholcaspis globulus, 134

Disonycha xanthomclaena, 161

Dissosteira carolina, 168

Dogwood clear-wing, 105 club gall, 105 twig girdler, 105

Donacia palmata, 175 piscatrix, 175

Drepanapliis acerifoliae, 127

Drepanosiphum platanoides, 127

Eastern spruce beetle, 162 tent caterpillar, 73

Ecdytolopha insiticiana, 127

Eelworms or nematodes, 170

Eight-spotted forester, 173
Elm leaf beetle, 106 scurfy scale, 106

Emphytina canadensis, 173

Emphytus cinctipes, 158

Empaasca fabae, 71, 82

Empria maculata, 166

Enarmonia prinivora, 76

Enchenopa binotata, 87

Epargyreus tityrus, 127

Epiblema suffusana, 158

Epicauta cinerea, 81 marginata, 80 pennsylvanica, 80

Epilachna borealis, 165 corrupta, 83

Epinotia nanana, 163

Epitrix cucumeris, 84, 151

Epizcuris aemula, 163

Epachra canadensis, 102

Eriocampoides limacina, 94

Eriococcus azaleae, 81 borealis, 162

Eriophyes amelanchieri, 159 avellanae, 116

fraxiniflora, 79

pyri, 141

sp., 108

Eriosoma americanum, 107

lanigera, 78

lanuginosa, 107

rileyi, 108

ulmi, 107

Erythroneura comes, 112

obliqua, 71

trifasciata, 120

vitis, 120

vulnerata, 174

Euceraphis deducta, 85

Eulia juglandana, 118 pinatubana, 146 velutinana, 75

Eumerus strigatus, 132

Eironymus scale, 108

European corn borer, 99 elm scale, 106 fruit lecanium, 147 pine shoot moth, 145 red mite, 74

Euschistus variolarius, 169

Euranessa antiopa, 107

Eiergestis straminalis, 95

Fall armyworm, 123 webworm, 141

False tarnished plant bug, 141

Feltia venerabilis, 136

Fenusa pumila, 86

Fern aphid, 108 scale, 109

Fidia viticida, 113

Fiorinia fioriniae, 91

Flat-headed apple tree borer, 74 
Flea beetles, 84

Forda olivacea, 135

Four-lined plant bug, 102

Fruit bark beetle or shot-hole borer, 138

Fuller's rose beetle, 156

Galerucella luteola, 106 nymphaeae, 175

Gall midge, 96

Garden flea hopper, 160 millipede, 171 slugs, 124 springtail, 84

Gelechia abietisella, 116

Geoica squamosa, 135

Giant hornet, 104

Gillettea cooleyi, 162

Gipsy noth, 74

Gladiolus thrips, 110

Glycobius speciosus, 128

Gooseberry fruit worm, 111 span-worm, 111

Gossyparia spuria, 106

Gracilaria syringella, 125

Grape berry moth, 111

flea beetle, 112

leafhopper, 112

phylloxera, 112

plume moth, 112

root worm, 113

scale, 113

Grapevine tomato gall, 113

Grapholitha molesta, 138

Grass thrips, 99

Greenhouse orthezia, 121 whitefly, 171

Green apple aphid, 75 clover worm, 83 fruit worm, 75 soldier bug, 83 -striped maple worm, 128

Halisidota caryae, 118 maculata, 118 tessellaris, $11 \mathrm{~s}$

Haltica chalybca, 112 citri, 160 ignita, 165 torquata, 88

Harmologa fumiferana, 162 Harpipteryx xylostella, 119

Hawthorn lacebun, 115

Hazel bud gall, 116 nut weevil, 116 whitefly, 116

Heliottiis obsoleta, 99

Hemadas nubilipennis, 88

Hemaris diffinis, 160

Hemerocampa leucostigma, 118

Hemerophila pariana, 71

Hemichionaspis aspidistrae, 109
Hemispherical scale, 109

Hemlock scale, 116 webworm, 116

Hessian fly, 176

Heterocampa guttivitta, 84

Hcterodera radicicola, 170

Hickory bark beetle, 117 gall aphid, 117 horned devil, 117 leaf galls, 117 leaf roller, 118 tussock moth, 118

Honeysuckle leaf roller, 119 sawflies, 119

Hormorus undulatus, 125

Horse-radish flea beetle, 119

Hyalopterus arundinis, 147

Hylemyia antiqua, 135 brassicae, 89 cilicrura, 100, 169 rubivora, 154

Hylobius pales, 145

Hypera punctata, 97

Hypermallus villosis, 134

Hyphantria cunea, 141

Hysteroneura setariae, 147

Idiocerus scurra, 149

Idiopterus neplurelepidis, 108

Illinoia pisi, 137

Imported birch leaf miner, 86 currant worm, 103 willow leaf beetle, 177

Ips calligraphus, 145 pini, 145

Iris borer, 120

Ischnaspis longirostris, 136

Ithycerus noveboracensis, 141

Itycorsia zappei, 146

Janus abbreviatus, 177 integer, 102

Japanese beetle, 157

Julus hortensis, 171

Juniper scale, 93 webworm, 121

Kermes sp., 134

Lacebugs, 81

Lachniella juniperivora, 92

Lachnus sabinae, 92

Laertias philenor, 105

Laphygma frugiperda, 123

Larch case bearer, 122 sawfly, 122 woolly aphid, 122

Lasioptera clavula, 105 vitis, 113

Laspeyrcsia interstinctana, 97

Leaf blister mite, 141 crumpler, 75 miners, 75, 81, 99 rollers, 75, 152 
Lecanium corni, 147

fletcheri, 79

nigrofasciatum, 129

Lema trilineata, 152

Leopard moth, 76, 107

Lepidosaphes ulmi, 76

Leptinotarsa decemlineata, 150

Lesser apple worm, 76 bulb fly, 132

Light-loving grapevine beetle, 83 , 113

Lilac borer, 124

leaf miner, 125

Lily-of-the-valley weevil, 125

Limax maximus, 124

Limonius agonus, 170

Lina scripta, 148

lapponica, 148

Linden borer, 125

Liosomaphis berberidis, 81

Listronotus latiusculus, 137

Lithocolletis fitchella, 133 hamadryadella, 133 tubiferclla, 133

Lixus concavus, 156

Locust borer, 126

leaf miner, 126

treehopper, 127

twig borer, 127

Longistigma caryae, 116

Lopidea media, 144

Lycophotia margaritosa sancia, 91

Lygaeonematus erichsoni, 122

Lygidea menda.x, 76

Lygus invitus, 141 pratensis, 78, 93

Macrobasis unicolor, 81

Macrodactylus subspinosus, 113,157

Macronoctua anista, 120

Macrophya simillima, 110

Macrosiphum coryli, 115

crataegi, 115

cucurbitae, 163

dirhodum, 156

granarium, 134

lilii, 125

liriodendri, 172

rosac, 156

rudbeckiae, 110

sanborni, 96

solanifolii, 150, 156

sanchi, 124

spiraecola, 161

taraxaci, 104

Magnolia scale, 127

Malacosoma americana, 73

Mamestra picta, 90

Mancascllus brachyurus, 175

Maple borer, 128

leaf scale, 128

leaf stem borer, 128

sesian, 128
Marguerite fly, 130

Mealybug, 79

flata, 125

Melalopha inclusa, 149

Melanopirila fulvoguttata, 116

Melanoplus atlanis, 114, 168 bivittatus, 114 femur-rubrum, 114, 168

Melanoxantherium medium, 148 populifoliae, 148 sinithiae, 148

Melaphis rhois, 166

Melon aphid, 130 worm, 130

Merodon equestris, 132

Metallus rubi, 87

Metriona bicolor, 167

Nexican bean beetle, 83

Hineola indiginella, 75 vaccinii, 101

Monarthropalpus buri, 88

Monellia caryae, 116 caryella, 116 costalis, 116

Monaphadnoides rubi, 155

Mordruilkoja vagabundus, 148

Morgan's scale, 159

Mulberry whitefly, 131

My ocallis asclepiadis, 154 discolor, 132 punctatellus, 132

Myzus cerasi, 94 circumflexum, 125

persicae, 161

porosus, 165

ribis, 102

rosarum, 156

violae, 173

Vectarosiphan rubi, 154

Veodiprion abietis, 163 lecantei, 146 pinetum, 146 pinus-rigidae, 146

Neolecanium comuparoum, 127

Neothomasia populicola, 148

Nephrotona ferruginia, 168

Nepticula sericapeza, 129

New York weevil, 141

Norway maple seed pod borer, 129

Nygmia phaeorrhaea, 140

Oak galls, 133 gall scale, 134

Oberea bimaculata, 154 tripunctata, 105

Odontoccra dorsalis, 99

Oecanthus nigricornis, 155

Oletlrentes hebesana, 173 hemidesma, 162

Omphalocera dentosa, 82

Onion maggot, 135 thrips, 136 
Orange-striped oak worm, 134

Oriental fruit moth, 138

Ormenis septentrionalis, 125

Ornix geminatella, 75

Orthe sia insignis, 121

Oxyptilus periscelidactylus, 112

Oyster-shell scale, 76

Pachystethus lucicola, 83, 113

Painted hickory borer, 118

Paleacrita vernata, 72

Pales weevil, 145

Palmer worm, 76

Pamphilius dentatus, 87 persicus, 139

Papaipema nitela, 104 purpurifascia, 97

Papilio polyxenes, 93

Paratetranychus bicolor, 133 pilosits, 74 ununguis, 163

Parsley stalk weevil, 137

Parsnip leaf miner, 137 webworm, 137

Pea aphid, 97, 137 weevil, 137

Peach borer, 139 sawfly, 139 twig borer, 139

Pear midge, 141 psylla, 142 thrips, 142

Pears injured by squirrels, 142

Pegomyia hyoscyami, 161

Pempligus populicaulis, 148

Pepper maggot, 144

Periphyllus americanus, 127 lyropicta, 127

Peronea minuta, 101

Phaedon aeruginosa, 175

Phelctes ectypus, 170

Phenacoccus acericola, 129

Phlegethontius quinquemaculata, 169,171 sexta, 169, 171

Phlepsius irroratus, 114

Phloeosinus dentatus, 93

Phlox bug, 144

Phlyctaenia rubigalis, 93

Pholus achemon, 114 pandorus, 114

Phyllaphis fagi, 84

Phyllocoptes aceris-crumena, 128 quadripes, 128 schlectendali, 152

Phyllophaga crenulata, 115 forsteri, 115

fraterna, 115

fusca, 115

hirticula, 115

Phyllotreta armoraciae, 119
Phylloxera caryaecaulis, 117 vitifoliae, 112

Phy'tomyza albiceps, 81 aquilc giana, 98 chrysanthemi, 130 minuscula, 98

Phytonomus nigrirostris, 97

Plytophaga destructor, 176 violicola, 173

Pickle worm, 101

Pieris rapae, 90

Pclidnota punctata, 114

Pine bark aphid, 145 bark beetles, 145 leaf scale, 146 pyralids, 146 sawflies, 146 spittle bug, 146 tube moth, 146

Pipe vine caterpillar, 105

Pissodcs strobi, 146

Pistol case bearer, 72

Pit-making oak scale, 134

Plagiodera versicolora, 177

Plathypena scabra, 83

Plum curculio, 147

Plutella maculipennis, 90

Podesesia syringae, 124

Poecilocapsus lineatus, 102

Polychrosis viteana, 111

Poplar and willow curculio, 148

Poplar borer, 148 leaf beetle, 148

Popillia japonica, 157

Porthetria dispar, 74

Potato aphid, 150 flea beetle, 151 stalk weevil, 151

Prionoxystus robiniae, 126

Prionus laticollis, 133

Priophorus acericaulis, 128

Prociphilus xylostei, 119

Pseudococcus adonid im, 121 citri, 79, 121 comstocki, 92

Psila rosae, 92

Pteronidea ribesii, 103

Pteronus ventralis, 177

Pulvinaria acericola, 128 vitis, 127

Purple-back cabbage worm, 95

Psyllia buxi, 88 pyricola, 142

Pyrausta nubilalis, 99

Quince curculio, 143, 153

Raspberry cane borer, 154 cane maggot, 154 fruit worm, 154 root borer, 155 sawfly, 155 
Red bug, 76

cedar bark beetle, 93

-humped caterpillar, 77

-necked cane borer, 87 spider, 144

Resplendent shield bearer, 153

Reticulitermes flavipes, 110

Rodent injury, 77

Root aphids, 81

Rophalosiphum nymphaeae, 175 prunifoliae, 82, 134

Rose chafer, 113, 157

curculio, 158

leafhopper, 158

leaf rollers, 158

midge, 158

sawflies, 158

scale, 158

stem girdler, 159

Rosy apple aphid, 77

Round-headed borer, 77

Rhabdophaga strobiloides, 177

Rhagoletis cingulata, 94 fausta, 94 pomonella, 72

Rhizobius lactucae, 124

Rhizoglyphus hyacinthi, 132

Rhododendron borer, 155 lacebug, 156

Rhopobota naevana, 100

Rhyacionia buoliana, 145

Rhynchites bicolor, 158

Saddled prominent, 84

Saissetia hemisphaerica, 109

San José scale, 143

Saperda calcarata, 148 candida, 77

fayi, 115

vestita, 125

Satin moth, 149

Scaptomyza flaveola, 132

Schizura concinna, 77

Scolytus quadrispinosus, 117 rugulosus, 138

Scurfy scale, 143

Seed corn maggot, 100, 169

Serpentine leaf miner, 132

Serviceberry gall mite, 159

Sesia acerni, 128

rhododendri, 155

scitula, 105

Silver-spotted skipper, 127

Sinuate pear borer, 143

Siphocoryne xylostei, 119, 137, 160

Sminthurus hortensis, 81

Snowberry clear-wing, 160

Soft scale, 109

Spanioneura fonscolombii, 88

Sphecodina abbotii, 114
Spinach aphid, 161

flea beetle, 161

leaf miner, 161

Spined tobacco bug, 169

Spiny elm caterpillar, 107

Spiraea leaf roller, 162 scale, 162

Spotted asparagus beetle, 80 cucumber beetle, 101 grapevine beetle, 114 hemlock borer, 116

Spruce budworm, 162 epizeuxis, 163 leaf miner, 163 mite, 163 sawfly, 163

Squash borer, 164 bug, 164 lady beetle, 165

Stalk borer, 104

Stcphanitis pyrioides, 81 rhododendri, 81, 156

Stilpnotia salicis, 149

Straussia longipennis, 167

Strawberry crown borer, 165 crown girdler, 165

flea beetle, 165 leaf roller, 166 sawfly, 166 weevil, 166 whitefly, 166

Striped cucumber beetle, 101

Simac psyllids, 167

Sunflower maggot, 167

Sycamore lacebing, 168 leaf folder, 168

Synanthedon tipuliformis, 102

Systena taeniata blanda, 84 frontalis, 84 hudsonias, 84

Tachypterellus quadrigibbus, 73

Taeniothrips gladioli, 110 inconsequens, 142

Tarnished plant bug, 78, 93, 139

Tarsonemus pallidus, 104

Terrapin scale, 129

Tetraleurodes mori, 131

Tetralopha mclanogrammos, 146 robustclla, 146

Tetranychus bimaculatus, 133, 144

Thecabius gravicornis, 148 populiconduplifolius, 148

Thecodiplosis liriodendri, 172 mosellana, 176

Therioaphis tiliae, 125

Thistle butterfly or painted lady, 118

Thorn limb borer, 115

Three-lined potato beetle, 152

Thrips tabaci, 136 
Tischeria malifoliella, 75

Tmetocera ocellana, 72

Tomato worm, 171

Tomostethus bardus, 79

Tortrix albicomana, 133, 158 quercifoliana, 133

Toumeyella liriodendri, 172

Toxoptera graminum, 134, 159

Tree cricket, 155

Trialeurodes coryli, 116 packardi, 166 vaporariorum, 171

Trichiocampus viminalis, 149

Trichobaris trinotata, 151

Trioza tripunctata, 87

Tulip tree scale, 172 spot gall, 172

Tussock moths, 78

Twig injury by squirrels, 107, 163

Twig pruner, 134

Two-lined chestnut borer, 95

Two-marked treehopper, 87

Tyloderma fragariae, 165

Typhlocyba pomaria, 71 rosae, 71,158

Vanduzea arquata, 127

Vanessa cardui, 118

Variegated cutworm, 91

Verbena budworm, 173

Vespa crabro, 104

Violet gall midge, 173 sawfly, 173
Walkingstick, 134

Walnut bud moth, 174 caterpillar, 174 scale, 174 weevil, 174

Vatercress leaf beetle, 175 sowbug, 175

Wheat midge, 176

White ant, 110 grubs, 100, 114 -marked tussock moth, 118 or oleander scale, 135 peach scale, 140 pine weevil, 146

Willow cone gall, 177 sawflies, 177

Wireworms, 170

Woodbine vein gall, 174

Woolly apple aphid, 78 elm aphids, 107 maple leaf scale, 129

Xylina antennata, 75 grotei, 75 laticinerea, 75

Yellow-headed cranberry worm, 101 necked caterpillar, 78 woolly bear, 173

Zebra caterpillar, 90 Zeusera pyrina, 107

Zonosema electa, 144

Zophodia grossulariae, 111 

$\begin{array}{lll}5388 & 18\end{array}$ 


University of

Connecticut

Libraries

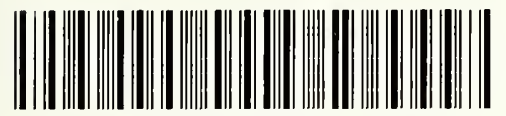

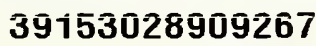


W. W

Whom

Hom

更

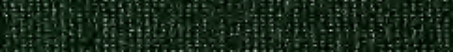

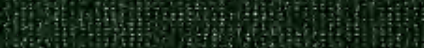

H.

4.

(5)

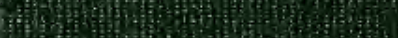

H.

(19)

(9)

(20)

What

(2)

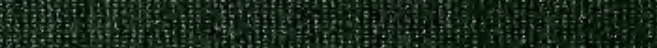

3.

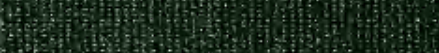

(9)

W

(9)

4.7.

W

Hon

16 (1)

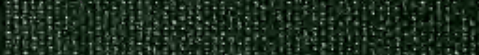

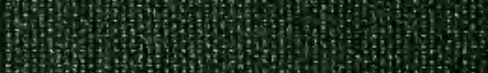

130

H.

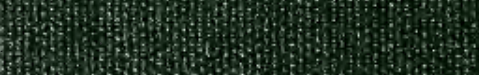
7. 